\title{
Worldwide Asbestos Supply and Consumption Trends from 1900 through 2003
}

Circular 1298 


\section{Worldwide Asbestos Supply and Consumption Trends from 1900 through 2003}

By Robert L. Virta

This Circular supersedes USGS Open-File Report 03-083

Circular 1298 


\title{
U.S. Department of the Interior DIRK KEMPTHORNE, Secretary
}

\author{
U.S. Geological Survey \\ Mark D. Myers, Director
}

\section{U.S. Geological Survey, Reston, Virginia: 2006}

For product and ordering information:

World Wide Web: http://www.usgs.gov/pubprod

Telephone: 1-888-ASK-USGS

For more information on the USGS—-the Federal source for science about the Earth, its natural and living resources, natural hazards, and the environment:

World Wide Web: http://www.usgs.gov

Telephone: 1-888-ASK-USGS

Any use of trade, product, or firm names is for descriptive purposes only and does not imply endorsement by the U.S. Government.

Although this report is in the public domain, permission must be secured from the individual copyright owners to reproduce any copyrighted materials contained within this report. 


\section{Contents}

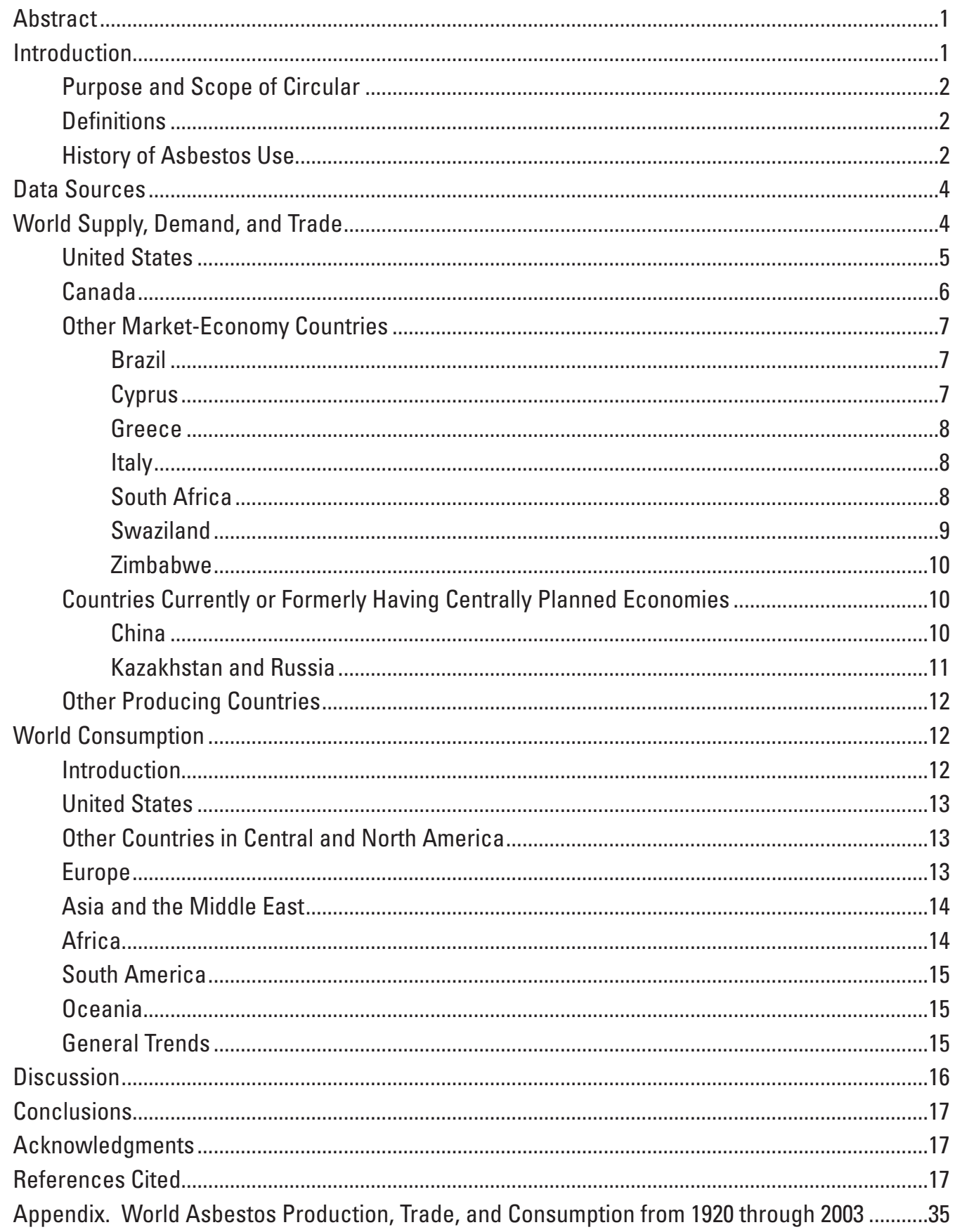




\section{Figures}

[Figures follow References Cited]

1. Bar graph of calculated apparent consumption of asbestos by region, 1920-2003....24

2-3. Line graphs of calculated apparent consumption of asbestos by major asbestosconsuming countries:

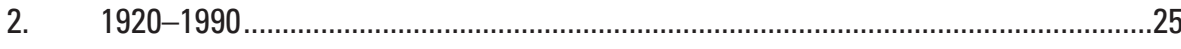

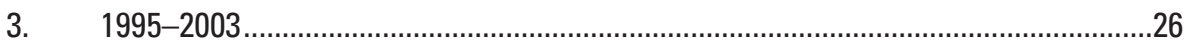

\section{Tables}

[Tables follow figures]

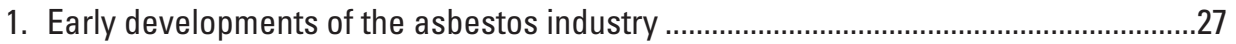

2. Salient U.S. statistics for asbestos, 1900 through 2003 ..............................................28

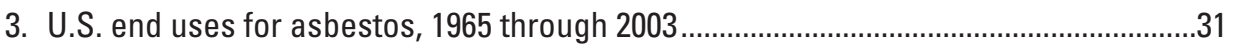

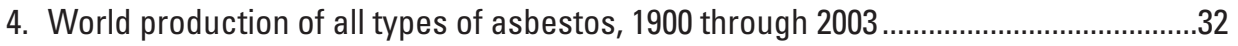

A1-A19. Asbestos production, trade, and consumption in-

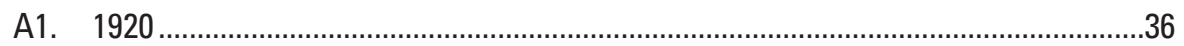

A2. $1930 \ldots \ldots \ldots$

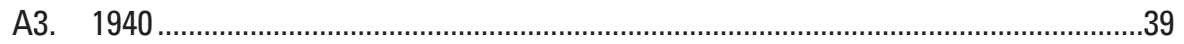

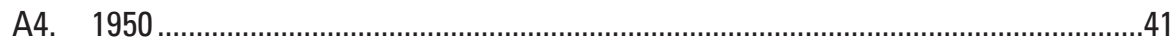

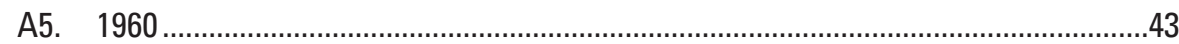

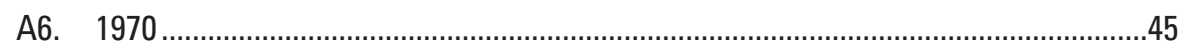

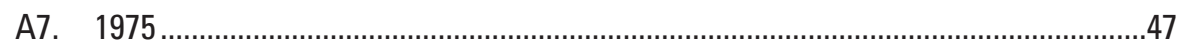

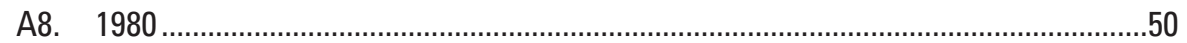

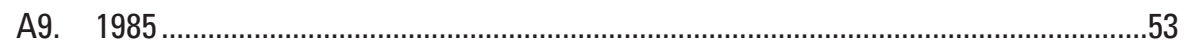

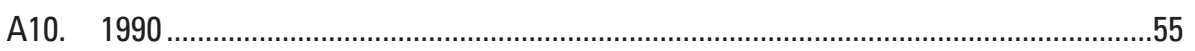

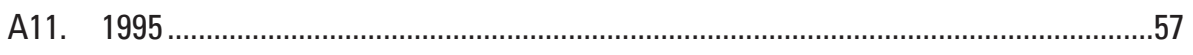

A12. $1996 \ldots \ldots \ldots \ldots$

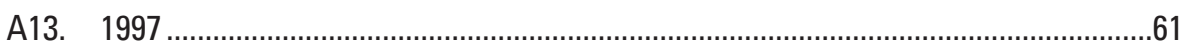

A14. $1998 \ldots \ldots \ldots \ldots+\cdots \cdots$

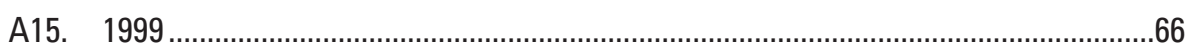

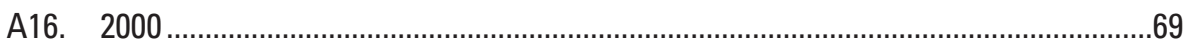

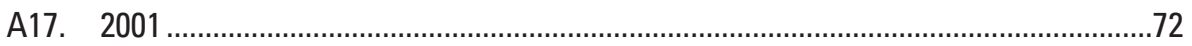

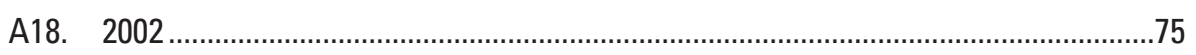

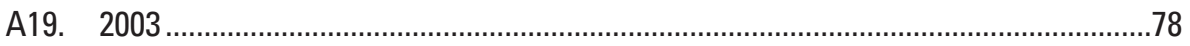

\section{Conversion Factors}

\begin{tabular}{lcl}
\hline Multiply & By & To obtain \\
\hline square meter & 10.76 & square foot \\
square meter & 1.196 & square yard \\
metric ton (t, 1,000 kilograms) & 1.102 & short ton $(2,000$ pounds) \\
\hline
\end{tabular}





\title{
Worldwide Asbestos Supply and Consumption Trends from 1900 through 2003
}

\author{
By Robert L. Virta
}

\section{Abstract}

This Circular updates and supersedes U.S. Geological Survey (USGS) Open-File Report 03-083, "Worldwide Asbestos Supply and Consumption Trends from 1900 to 2000," with the addition of supply and consumption estimates and analysis from 2001 through 2003 and revisions to the consumption estimates for 1998 through 2000. The text from Open-File Report 03-083 also has been updated in this Circular to include revisions to and expansion of the time-series coverage.

The use of asbestos is one of the most controversial issues surrounding the industrial minerals industry. Its carcinogenic nature, an overall lack of knowledge of minimum safe exposure levels, its widespread use for more than 100 years, and the long latency for the development of lung cancer and mesothelioma are the main contributing factors to these controversies. Another factor is that, despite decades of research, the mechanisms responsible for its carcinogenic properties are still largely unknown.

The United States produced about 3.29 million metric tons (Mt) of asbestos and used approximately $31.5 \mathrm{Mt}$ between 1900 and 2003. About half of this amount was used after 1960. In 2002, the last asbestos mine in the United States closed, marking the end of more than 110 years of U.S. asbestos production. Cumulative world production from 1900 through 2003 was about $181 \mathrm{Mt}$. If one assumes that unusually large stocks were not maintained and that world consumption roughly equaled production, then about half of the world production and consumption occurred between the end of 1976 and the end of 2003.

The United States and Western European nations were the largest consumers of asbestos during the first two-thirds of the 20th century. They were surpassed by the collective production and consumption of Kazakhstan and Russia by the 1970s. After the onset of the health issues concerning asbestos in the late 1960s and early 1970s, the decline in world production and consumption began to be evident in the late 1970s and early 1980s. The 1991 breakup of the Soviet Union, a major user of asbestos, resulted in a significant decline in asbestos consumption and production in former Soviet-bloc countries. Consumption and production in Kazakhstan and Russia increased through 2003 from 2001, albeit to a much lower level than in the 1980 s.

In 2003, world consumption was estimated to be 2.11 Mt, about 45 percent that of 1980 . Relatively few countries in Asia, the Middle East, South America, and the former Soviet Union remained as the leading users of asbestos. China was the leading consuming nation, using an estimated 492,000 metric tons $(\mathrm{t})$ in 2003. China was followed, in decreasing order of consumption, by Russia (429,000 t), India (192,000 t), Kazakhstan (174,000 t), Ukraine (156,000 t), Thailand (133,000 t), Brazil $(78,400 t)$, and Iran (75,800 t). These eight countries accounted for 82 percent of the world's apparent consumption in 2003. Following Iran, in decreasing order of consumption by tonnage, were Uzbekistan $(42,400 \mathrm{t})$, Vietnam $(39,400 \mathrm{t})$, Indonesia (32,300 t), the Republic of Korea (23,800 t), Kyrgyzstan (23,700 t), Japan (23,400 t), and Mexico (20,100 t). Consumption in all other countries was estimated to be less than 15,000 $\mathrm{t}$ each in 2003. Sizable consumption increases occurred in Azerbaijan, China, India, Iran, Kazakhstan, Thailand, and Ukraine between 2000 and the end of 2003. Consumption patterns in countries using less than 5,000 t per year were too erratic to ascertain any trends in their use of asbestos.

\section{Introduction}

The use of asbestos is one of the most controversial issues surrounding the industrial minerals industry. Its carcinogenic nature, an overall lack of knowledge of minimum safe exposure levels, its widespread use for more than 100 years, and the long latency for the development of lung cancer and mesothelioma are the main contributing factors to these controversies. Another factor is that, despite decades of research, the mechanisms responsible for its carcinogenic properties are still largely unknown.

The United States produced about 3.29 million metric tons (Mt) of asbestos and used approximately $31.5 \mathrm{Mt}$ between 
1900 and 2003. In 2002, the last asbestos mine in the United States closed, marking the end of more than 110 years of U.S. asbestos production. Cumulative world production from 1900 through 2003 was about $181 \mathrm{Mt}$. If one assumes that unsually large stocks were not maintained and that world consumption roughly equaled production, then about half of the world production and consumption occurred between the end of 1976 and the end of 2003.

\section{Purpose and Scope of Circular}

Of interest, from a historical and exposure standpoint, is how much asbestos was used in each country over time. This information provides a means by which to determine past, current, and future markets for asbestos and some insight into the potential for past occupational asbestos exposures in various countries. Total and market-specific usage data for asbestos generally are lacking because most countries did not have the resources or feel the need to gather and evaluate that kind of information. Even in the United States, only asbestos production (sales) data have been tracked for more than 100 years; import data were not gathered until 1931, and asbestos consumption by market was not documented until about 1972 , with only estimates extending back to 1965 . This Circular reviews production and market changes throughout the world and provides some insight into the levels of asbestos use in individual countries over time.

This Circular updates and supersedes U.S. Geological Survey (USGS) Open-File Report 03-083, "Worldwide Asbestos Supply and Consumption Trends from 1900 to 2000," with the addition of supply and consumption estimates and analysis from 2001 through 2003 and revisions to the consumption estimates for 1998 through 2000. The text from Open-File Report 03-083 also has been updated in this Circular to include revisions to and expansion of the time-series coverage.

After the introduction and identification of data sources, this Circular provides information on asbestos trends in two main sections: "World Supply, Demand, and Trade" and "World Consumption." Table 1 summarizes early developments in the asbestos industry; table 2 has salient U.S. statistics for asbestos, table 3 has U.S. end uses for asbestos, and table 4 has world production data for asbestos. Figures 1, 2 , and 3 are graphs of apparent consumption of asbestos by region and country; figures and tables follow the "References Cited." The text is supplemented by the appendix, in which tables A1-A19 provide snapshots of world production, trade, and consumption of asbestos at specific times: for 1920-1970, at 10-year intervals; for 1970 through 1995, at 5-year intervals; and for 1996 through 2003, annually.

Data in the appendix tables are presented for individual countries and regions. To form the regions, countries are grouped by continent with a few exceptions. Middle Eastern countries are grouped with Asia. Eastern countries of the former Soviet Union, despite being in Asia, are included in Europe so as to be grouped with Russia and other western countries of the former Soviet Union and to facilitate comparisons of data for the same region at different times.

\section{Definitions}

Asbestos is a generic name given to the fibrous variety of six naturally occuring minerals that have been used in commercial products (Virta, 2001). The term "asbestos" is not a mineralogical definition. It is a commercial designation for mineral products that possess high tensile strength, flexibility, resistance to chemical and thermal degradation, and high electrical resistance and that can be woven.

Minerals that can crystallize as asbestos belong to two groups: serpentine and amphibole. The asbestos variety of serpentine is chrysotile. Most of the asbestos used after the late 1800s was chrysotile. The commercial asbestos varieties of amphibole include the following: crocidolite (riebeckite asbestos), amosite (cummingtonite-grunerite asbestos), anthophyllite asbestos, tremolite asbestos, and actinolite asbestos. These types were mined over the long history of asbestos use.

\section{History of Asbestos Use}

Asbestos use began about 4,500 years ago. Early evidence of its use to strengthen clay pottery as long ago as 2500 B.C. has been found in Finland (Selikoff and Lee, 1978, p. 6-7; Gross and Braun, 1984, p. 9). Anecdotes about its use have been reported by many, including Pliny the Elder (about 79 B.C.) and Marco Polo (about A.D. 1250) (Bowles, 1946, p. 13-14). Some of the earlier uses were in crematory shrouds, lamp wicks, and incombustible napkins and tablecloths. The tablecloths could be tossed in the fire to be cleaned without fear of damage (Becker \& Haag, 1928, p. 14-16; Bowles, 1937, p. 5-7; Sinclair, 1959, p. 1-3; Natural Resources Board of Southern Rhodesia, 1963). Ben Franklin reportedly used an asbestos purse, not to protect his money, but to prevent it from burning the proverbial hole in his pocket (Alleman and Mossman, 1997).

The modern asbestos industry began in the early $1800 \mathrm{~s}$ when a textile manufacturing industry was established in Italy to produce such items as fabrics, string, and book covers (Bowles, 1946, p. 14; Sinclair, 1959, p. 3, 277; Alleman and Mossman, 1997). Consumption at that stage still was extremely low compared with 20th century usage. With increased industrialization, new uses were developed to take advantage of the strength, heat resistance, and flexibility of asbestos fibers. These uses included packings for steam glands on high-temperature machines, insulation for boilers and steampipes, and fireproof paint and wall materials. Textiles remained a small yet valuable market during this period of expanded use (Sinclair, 1959, p. 278; Alleman and Mossman, 1997).

As the asbestos manufacturing industry grew worldwide in the late 1800 s, concerns over supply arose because production in Italy, the world's primary supplier of asbestos, 
and other countries totaled only a few thousand tons per year (Bowles, 1934, p. 7-24; Howling, 1937, p. 59; Selikoff and Lee, 1978, p. 14). The discovery and development of large asbestos deposits in Canada, Russia, and South Africa in the late 1800s resolved the supply issue (Sinclair, 1959, p. 3; Selikoff and Lee, 1978, p. 8).

A timeline listing significant developments in the early history of the asbestos industry was published in 1953 (Stover Publishing Co., 1953, p. 4-6). Selikoff and Lee (1978, p. 17-18) presented a historical timeline of significant events regarding the development of the asbestos industry through 1972. Several of the more important of these developments are listed in table 1.

In 1907, the development of the Hatschek machine for making asbestos-cement flat and corrugated panels resulted in a significant increase in demand for asbestos (Rosato, 1959, p. 63; Sinclair, 1959, p. 279). This technology enabled the mass production of inexpensive, fireproof building materials. In 1929, a process was developed for the mass production of asbestos-cement pipe, enabling its widespread use in watersupply and waste lines (Rosato, 1959, p. 79). Simultaneously, the rise of the automobile industry in the early 1900s resulted in an increased demand for asbestos for the manufacture of brakes, clutch components, and engine gaskets (Sinclair, 1959, p. 278). These developments resulted in a rapid increase in the use of asbestos worldwide. By 1910, world production exceeded 109,000 metric tons (t), which was more than three times as much as production in 1900 (table 4). In 1910, the United States was the leading user of asbestos in the world, consuming an estimated 43 percent of world production (tables 2 and 4).

Production and consumption declined during World War I and the Great Depression of the 1930s. Immediately after both events, there was rapid growth in construction and other market sectors, which continued into the 1940s. Sales and use of asbestos increased to meet the demands of these new and expanding markets. In addition to automotive and asbestoscement products, demand grew for asbestos millboard and paper for electrical panels; textiles for insulating electrical wiring; spray-on asbestos products for protecting steel girders in buildings; reinforcing, heat-resistant fillers for plastics; fire-resistant roofing materials such as asbestos felts, shingles, and asphalt roofing compounds; inexpensive, durable, and dimensionally stable flooring products, such as vinyl asbestos tile and flooring felts; heat- and acid-resistant gaskets and packings; thermal insulation on boiler systems for buildings and homes; fireproof suits for firefighters; reinforcement for plasters and caulking compounds; and filler and reinforcer in paints and asphalt road surfacing (Stover Publishing Co., 1953, p. 9-15; Rosato, 1959, p. 23-27; Selikoff and Lee, 1978, p. 19-20; Cossette and Delvaux, 1979, p. 104-107; Roskill Information Services Ltd., 1990, p. 99-126).

The onset of World War II resulted in declining production in most regions of the globe except Canada, South Africa, and the United States. While asbestos production and use declined worldwide, U.S. war demands absorbed much of the increased production from Canada, South Africa, and the United States. U.S. consumption increased to about 60 percent of world production in 1942 from 37 percent in 1934 (tables 2 and 4). However, postwar reconstruction and recovering economies again resulted in increased world demand for asbestos, and production of asbestos increased to supply these demands.

By 1958, asbestos was used in about 3,000 applications (Quebec Asbestos Information Service, 1959). By this time, asbestos was being honored for its "service to humanity" (Alleman and Mossman, 1997) and called a "boon to humanity" (Bowles, 1946, p. 6) and "faithful servant of mankind" (Bowles, 1946, p. 37), "the most important of the non-metallic mineral products of the world-and certainly one of the most wonderful" (Summers, 1919, p. 10), and even the "magic mineral” (Quebec Asbestos Information Service, 1959).

The myriad uses of asbestos resulted in a continued increase in demand for asbestos after World War II. Peak demand for asbestos was achieved around 1977, when about 25 countries were producing a total of almost $4.8 \mathrm{Mt}$ per year of asbestos, and about 85 countries were manufacturing asbestos products (table 4). In the United States and, to a lesser extent, in many European countries, the use of asbestos waned in the early to late 1970s (Alleman and Mossman, 1997). Health research conducted during the 1920s to 1940 s had revealed an association between exposure to asbestos and asbestosis, but in the late 1950s and early 1960s, an association between asbestos exposure and lung cancer was conclusively proven (Selikoff and Lee, 1978, p. 22-23, 31-32; Gross and Braun, 1984, p. 20-21; U.S. Department of Health and Human Services, 1992, p. 33-34). With that finding, public opposition to the use of asbestos increased significantly.

Liability also became a major issue for producers and manufacturers. In the United States, asbestos producers and manufacturers of asbestos products faced an increasing number of class-action lawsuits filed on behalf of those suffering from asbestos-related diseases (Virta, 2002, p. 15). This liability contributed to a shift by many product manufacturers to (1) asbestos substitutes, such as aramid fiber, cellulose fiber, polyvinyl alcohol fibers, or wollastonite, or (2) alternative products, such as fiberglass shingles, mineral wool insulation, ductile iron and polyvinyl chloride pipe, graphite packings, metallic disk brake pads, and aluminum siding (Hodgson, 1989; Virta, 1994). Similar movements toward the use of nonasbestos products followed in many other countries, particularly in Western Europe.

The health and liability factors resulted in a dramatic decline in the use of asbestos in the industrialized countries after the mid-1970s, a movement toward increasingly strict exposure limits for occupational settings, new consumer and environmental regulations, and, by 2003, full or partial bans on the use of asbestos in 16 countries-Argentina, Austria, Belgium, Chile, Denmark, Finland, France, Germany, Italy, Netherlands, Norway, Poland, Saudi Arabia, Sweden, Switzerland, and the United Kingdom. Additionally, the European Union (EU) banned the use of asbestos, with some exemp- 
tions, in 2005. Despite the bans and restrictions, many countries still consider asbestos use vital to their development, as shown in the appendix.

\section{Data Sources}

The data cited in this Circular were extracted from a variety of sources because no single source contains a complete set of all statistics needed. For the United States, annual compilations of mineral data for the last century were published under two titles by the U.S. Geological Survey (USGS) and the U.S. Bureau of Mines (USBM) as responsibilities were periodically reassigned. The two sources used were "Mineral Resources of the United States" (USGS, 1901-1926; USBM, 1927-1933) and "Minerals Yearbook" (USBM, 1933-1996; USGS, 1997-2005). Asbestos chapters in these two sources are cited under the agencies as shown in the previous sentence; in addition, selected asbestos chapters are cited by personal author names when a specific credit is needed. Chapters on mineral industries of other countries were published in international volumes of the USBM and USGS "Minerals Yearbook" for 1963 through 2003; they are cited by personal author names.

Also used in compiling this Circular were asbestos chapters in the "Statistical Summary of the Mineral Industry" and "World Mineral Statistics" and their predecessor reports by the British Geological Survey (BGS) and its forerunners (Great Britain Imperial Mineral Resources Bureau, 1924; Great Britain Imperial Institute, 1932, 1948; Great Britain Colonial Geological Surveys, 1956; Great Britain Institute of Geological Sciences, Overseas Division, 1967; Great Britain Institute of Geological Sciences, 1973, 1981; BGS, 1984, 1991, 1995, 2001, 2002). Other resources include asbestos and chrysotile chapters of the "Canadian Minerals Yearbook" (Vagt, 1975; Hoskin, 1991; Perron, 2001, 2003) and reports on the South African asbestos industry (Gössling, 1977; Griffiths, 1989, p. 21; van der Merwe, 1989; Munzhelele, 2000). International trade data for 1998 through 2003 were obtained from the United Nations (UN) Statistics Division (2005).

In general, revisions to statistical data have not been published in any systematic fashion. As a result, data from various sources frequently do not agree for any given year. Another problem is that data by country were often revised but not published; only the revised total world production data were published. Thus, the sum of production of individual countries may not equal the revised world production for a given year. Another problem is that the data are a mix of ore production, fiber production, and fiber sold or used. Ore production consists of crude rock and asbestos, fiber production consists of asbestos fiber recovered through the processing of crude ore, and fiber sold or used is asbestos fiber entering commerce during the year. Also, data were not available from all countries for all years. When estimates were made in publications, usually there was no indication that data were estimates or any indications of how the estimates were made. There is no way to resolve these problems short of the impossible task of retrieving all of the survey data, and so they will have to be accepted as a limitation of this historical review.

When possible, data were extracted from one source to maintain consistency over the longest period of time. For the next section of the Circular, entitled "World Supply, Demand, and Trade," data extracted from the USBM and USGS "Minerals Yearbook" chapters on asbestos were used as the basis for the evaluation. Many of the data are available in the asbestos chapter on the USGS Web site at http://minerals.usgs.gov ds/2005/140 (Buckingham and Virta, 2006). Some of the numbers under "World Supply, Demand, and Trade" do not match those of Buckingham and Virta (2006) because estimates for nonresponding survey countries are included in this Circular. These estimates were based on world asbestos market conditions, accounts from other data sources, and long-term production trends within the country. Adjustments also were made for countries reporting crude ore production rather than fiber production.

For the section "World Consumption," data extracted from the publications of the BGS and its predecessor agencies were used to calculate the apparent consumption for each country for 1920 through 1997; see appendix tables A1 through A13. When discrepancies arose or data were not available in the BGS publications, data extracted from the abovementioned references or estimates that were the most consistent with market conditions at the time were used. After 1997, production data reported in the USGS "Minerals Yearbook" chapters on asbestos (USGS, 1997-2005) and trade data from the UN Statistics Division (2005) were used to estimate world consumption; see appendix tables A14 through A19.

As noted in USGS Open-File Report 03-083 (Virta, 2003b), a calculated trade imbalance began to be evident in 1998, worsening by 2000. This apparent imbalance resulted because trade data for all countries were not available at the time that Open-File Report 03-083 was published. This problem was resolved by using UN Statistics Division (2005) trade data for 1998 onward.

Despite the caveats, the data are deemed sufficiently reliable to make a fairly accurate evaluation of asbestos consumption trends worldwide as well as those of regions and individual countries. The reader should note, however, that the tables in the Circular body and appendix are snapshots of world activities at a particular time. Activities that may have occurred during the intervals are not taken into consideration.

\section{World Supply, Demand, and Trade}

The following section includes descriptions of asbestos trends in the United States, Canada, and the following three groups: other market-economy countries (in which countries are discussed alphabetically), countries currently and formerly having centrally planned economies, and other producing 
countries. For consistency, data used in this section were extracted from the USBM and USGS "Mineral Resources of the United States" and "Minerals Yearbook" (USGS, 19011926, 1997-2005; USBM, 1927-1933, 1933-1996). See the section "Data Sources" for further explanation.

\section{United States}

Commercial asbestos production has been recorded in 15 States since 1900: Alaska, Arizona, California, Georgia, Maryland, Massachusetts, Montana, North Carolina, Oregon, Pennsylvania, South Carolina, South Dakota, Vermont, Virginia, and Wyoming. There probably were small amounts of unrecorded production in additional States. The largest producer States were Arizona, California, North Carolina, and Vermont. Most of the asbestos mined in the United States was chrysotile, although much of the early production was of amphibole asbestos. These amphibole asbestos mines generally were short lived. The longest sustained production of amphibole asbestos was from North Carolina, where anthophyllite asbestos was mined from the early 1930s to 1979 (USGS, 1901-1926, 1997-2005; USBM, 1927-1933, 19331996; Bowles, 1934, p. 2-7, 1959, p. 6-7).

U.S. asbestos production was relatively low at the start of the 20th century, less than 10,000 tons per year until 1936 (see table 2, column labeled "Domestic sales or use," which is equivalent to production). After the Great Depression of the early 1930s and with the onset of World War II, U.S. production increased through 1942 to meet increased war demands. After 1942 and during the recession following World War II, demand and, consequently, U.S. production declined, not regaining their former levels for another 6 years. It wasn't until 1965 that U.S. production reached 100,000 metric tons per year (t/yr). Annual world production by 1965 had already exceeded 2.8 Mt (table 4). U.S. production exceeded 100,000 t/yr for only 10 years, 1965 to 1973 and in 1976. Peak production was about $136,000 \mathrm{t}$ in 1973 , which was 3 percent of the world's asbestos production and only 17 percent of the U.S. demand for that year (see table 2, where demand is equivalent to "Apparent consumption"). After 1973, the asbestos health controversy began to seriously affect demand, causing U.S. production to stagnate and then take a precipitous decline. The production of 5,000 $\mathrm{t}$ in 2001 was only 4 percent of the peak in 1973. In 2002, the last asbestos mine in the United States closed, marking the end of more than 110 years of U.S. asbestos production.

Despite having produced 3.29 Mt of asbestos between 1900 and the end of 2003, the United States almost always was dependent on imports to meet most of its demand. Imports supplied 94 percent of the U.S. asbestos needs during 1900 through 2003. For only 8 of those 104 years (1967, 1969-1973, 1975, and 1985) was U.S. import dependence (calculated as imports divided by apparent consumption) less than 90 percent. Canada was the major supplier of asbestos to the United States throughout most of the century, averag- ing 94 percent from 1910 to 2003. South Africa supplied up to 6 percent of U.S. imports but averaged 4 percent after 1915 (table 2). Swaziland and Zimbabwe were two other lesser, yet important, suppliers of asbestos to the United States.

About 98 percent of the 29.6 Mt of asbestos imported into the United States between 1900 and the end of 2003 was chrysotile, mostly from Canada. Crocidolite imports were $364,000 \mathrm{t}$ (1.2 percent of total asbestos imports) and amosite imports were 282,000 t (1 percent of total imports). About 34,200 t of anthophyllite asbestos were imported from Finland, the major supplier. The United States has not imported amosite since 1985 and has not imported crocidolite since about 1995. Most of the asbestos imports reported as crocidolite after 1995 are believed to be chrysotile on the basis of their sources and customs values (table 2).

Asbestos consumption in the United States was minimal in the 1800s. At that stage, markets primarily were such applications as textiles (fireproof cloth used to manufacture such items as boots, gloves, and theater curtains) and insulation and packings for steam locomotive and other boiler systems (Bowles, 1937, p. 8-10). Consumption did not increase significantly until the early 1900 s, when an expanding population and increased industrialization resulted in a demand for a steady supply of cost-effective, mass-produced construction materials. Asbestos products that filled this need included asbestos-cement pipes and sheets, coatings and compounds, flooring, friction materials such as brakes and clutches, and insulation. These were the large tonnage uses for asbestos. Other smaller, but still important, applications were in asbestos paper, asphalt emulsions, gaskets, packings, plastics, roofing felts, shingles, and textiles (Clifton, 1976, 1980b, 1985).

Starting from a rather small apparent consumption of $20,400 \mathrm{t} / \mathrm{yr}$ in 1900 , U.S. markets expanded to a peak of $803,000 \mathrm{t} / \mathrm{yr}$ in 1973 . Demand after 1900 was fairly continuous, with a short period of rapid growth in demand during World War I. The end of the Great Depression by the middle 1930s and the onset of World War II in the late 1930s brought about a brief surge in demand to meet U.S. requirements. After 1950, demand increased in step with economic growth in the United States. There was a general flattening of the demand curve in the 1950s during the Korean conflict and later in the early 1970s. The flattening of demand occurred after the early 1970s because the use of asbestos was becoming controversial and markets for asbestos in the United States appear to have matured. After 1973, asbestos consumption declined rapidly. By 2000, consumption was only about $15,000 \mathrm{t}$, or 1.9 percent of the level in 1973 and equivalent to consumption in the late 1800s. In 2003, U.S. consumption was 4,650 t (table 2).

In relation to overall world consumption, the United States was the largest market economy and world user of asbestos during much of the 20th century. U.S. asbestos use was high because much of the early manufacturing research was conducted in the United States, industrial demand for asbestos grew rapidly in the early 1900s, and a ready supply of asbestos was just across the border in Canada (Sinclair, 1959, p. 279). The United States used about 17 percent of 
the world's asbestos production between 1900 and the end of 2003. This long-term percentage is remarkable because after 1980, the U.S. annual share consistently was less than 10 percent. Between 1900 and the end of 1949, U.S. apparent consumption averaged 63 percent of world production and increased in times of war. This average clearly demonstrated the strength of the U.S. asbestos industry in its early history. As more countries developed asbestos-manufacturing industries after World War II, the U.S. share of the world market declined, averaging 13 percent from 1950 through 2003 (tables 2 and 4).

Following World War II, demand for asbestos fiber increased at a faster rate in other parts of the world than in the United States. Much of this growth was spurred by the massive reconstruction efforts in Europe after the war and later by growing economies. Consumption in the United States declined from 51 percent of the world production in 1950 to 19 percent in 1970 . With the onset of awareness of the asbestos health issues, U.S. consumption declined even further. By 1975, U.S. consumption was 13 percent of world production; by 1985,4 percent; and by 2000, less than 1 percent (tables 2 and 4).

About 71 percent of the U.S. consumption of asbestos occurred between 1950 and the end of 2003, about 50 percent occurred between 1960 and the end of 2003, and about 39 percent occurred after 1965, which is the year of the earliest available estimate of U.S. asbestos consumption by market share (tables 2 and 3). Thus, a fair idea of the markets into which a sizable share of the asbestos went throughout most of the history of U.S. asbestos usage can be determined. Table 3 presents the end-use data for asbestos from 1965 through 2003. The totals in table 2 do not match exactly the apparent consumption totals in table 3 because table 2 includes changes in government and industry stocks where available and because table 3 excludes amounts smaller than $500 \mathrm{t}$. With that caveat, the average percentage breakout of the major U.S. markets between 1965 and the end of 2003 follows: flooring, 21 percent; asbestos-cement pipe, 18 percent; roofing products, 12 percent; friction products, 11 percent; asbestoscement sheet, 6 percent; packing and gaskets, 4 percent; paper, 3 percent; coatings and compounds, electrical insulation, and textiles, 2 percent each; plastics and thermal insulation, less than 1 percent each; and other, 18 percent (table 3 ).

Because of the asbestos health issue, markets changed over this time period (table 3 ). The largest losses were in asbestos-cement pipe and sheet, coatings and compounds, flooring, and insulation. In 1965, before concerns about the asbestos health issue intensified, flooring accounted for 25 percent of the market share, followed by asbestos-cement pipe (19 percent), roofing (10 percent), friction products (8.9 percent), asbestos-cement sheet (6.9 percent), electrical insulation and packing and gaskets ( 3 percent each), paper and textiles (2 percent each), coatings and compounds and plastics (less than 1 percent each), and other uses (20 percent). By 1980, consumption was 19.5 percent for flooring, followed by friction products (14.5 percent), asbestos-cement pipe
(11.7 percent), roofing (6.7 percent), asbestos-cement sheet (6.4 percent), packing and gaskets (3.3 percent), coatings and compounds (3.1 percent), electrical insulation ( 1.7 percent), thermal insulation $(0.8$ percent $)$, plastics and textiles $(0.6$ percent each), paper ( 0.3 percent), and other uses (30.9 percent) (Clifton, 1976, 1980b, 1985). In 2000, the end-use markets were roofing ( 60 percent), gaskets ( 20 percent; packings were no longer being manufactured in the United States), friction products (13.3 percent), coatings and compounds, plastics, and other uses (6.7 percent) (Virta, 2003a). By 2003, coatings and compounds accounted for 25 percent of consumption; roofing products, 60 percent; and other uses, 15 percent (Virta, 2005a).

Some anecdotal information on markets before 1965 is available. Josephson and Marsh (1948) reported that U.S. usage of asbestos grades of shorter length in floor tile began to increase rapidly following the development of suitable production methods. Production of asbestos floor tile increased to 34,681 million square meters (41,479 million square yards) in 1947 from just 4,124 million square meters (4,933 million square yards) in 1939, an 8-fold increase in as many years. Corrugated sheet production increased to 4,258 million square meters (45,839 million square feet) in 1947 from 701 million square meters (7,551 million square feet) in 1939 . Less dramatic but still substantial increases were recorded in many other product categories (Josephson and Barsigian, 1950). Kennedy and Foley (1960) reported that 96 percent of the chrysotile used in the United States in 1959 was used principally in asbestos-cement and asbestos-asphalt building materials.

\section{Canada}

Chrysotile mining began in Canada around 1878 (Bowles and Barsigian, 1945; Sinclair, 1959, p. 3). By 1920, Canada already was producing about $162,000 \mathrm{t} / \mathrm{yr}$, or 84 percent of the world's production (table 4). Production suffered in the early 1930s because of the Great Depression in the United States (the largest Canadian market) and recessions worldwide that affected the entire asbestos industry. By 1935, the U.S. economic recovery bolstered the Canadian asbestos industry. The onset of World War II slowed production around 1940, but it recovered around 1946. During that time, mines and mill capacities in Canada were being increased rapidly to meet growing world demand (Josephson and Marsh, 1948). Production was slowed briefly by a strike in the Canadian industry in 1949 (Josephson and Barsigian, 1951) but quickly resumed following resolution of the dispute. Despite Russia emerging as a major asbestos-producing republic of the former Soviet Union, Canada still retained 61 percent of global production in 1950 (table 4).

Competition arose as Italy, Russia, South Africa, Swaziland, the United States, and Zimbabwe began to increase their production in the 1940s and 1950s (table 4), soon to be followed by China in the early 1960s and Brazil and Cyprus in the mid-1970s. By 1960, Canada's share of global production 
declined to 46 percent despite an increase in its production. Canadian production peaked in the 1970s (table 4), almost coinciding with the peak U.S. consumption (table 2), as would be expected because the United States was the major destination for Canadian asbestos. Then, in 1975, the Canadian asbestos producers suffered from a major mill fire, a landslide in a major mine, strikes, and political and transportation issues, resulting in a sharp (36 percent) decline in production (Vance, 1975). The industry rebounded quickly, however, only to face the asbestos health issue, which began in the United States in the early 1970 s and quickly spread to other countries. Two other factors affecting sales were declines in some of the world economies and political instability in some of the developing nations, which were important purchasers of Canadian asbestos in the late 1970s (Roskill Information Services Ltd., 1983, p. 20). Canadian production declined through 2000 as asbestos markets worldwide waned. By 2003, Canadian production was 200,500 t, or 9 percent of world production, down from 43 percent in 1970. Canada produced about 61.2 Mt of asbestos between 1900 and the end of 2003, all of it chrysotile (table 4).

Canada, for the most part, has been a major exporter of asbestos over time. Roughly 77 percent of Canadian production has been exported since 1900, with exports exceeding 80 percent since 1960. The United States was the largest market for exported Canadian asbestos. In 1930, U.S. asbestos imports from Canada were 181,000 t (table 2), or about 83 percent of Canadian production (table 4). U.S. imports declined during the Great Depression in the United States in the early 1930s but picked up again during World War II. The United States imported about 65 percent of Canadian production in 1940. U.S. imports from Canada accounted for 78 percent of Canadian production in 1950, 37 percent in 1970 (as the asbestos health issue was developing), 6 percent in 1990, and about 2.2 percent in 2003 (USBM, 1933-1996; USGS, 1997-2005).

Canadian asbestos producers had developed a broad range of customers before the decline of the U.S. market, and so those countries soon moved ahead of the United States as the major Canadian customers. As U.S. markets changed, the proportions of asbestos grades exported to the United States also changed. In 1973, the U.S shares of all Canadian exports were divided among asbestos grades as follows: 34 percent (11 of $32 \mathrm{t}$ ) of crude fiber, 24 percent $(203,000$ of $837,000 \mathrm{t}$ ) of milled fiber (groups 3, 4, and 5), and 59 percent (498,000 of 846,000 t) of short fiber (groups 6 to 9) (Vagt, 1975). Groups are Canadian asbestos product designations with group 3 containing a higher proportion of longer fibers than group 4, group 4 containing a higher proportion of longer fibers than group 5, and so forth. Among Canadian customers in 1973, the United States was followed by Japan for crude fiber, Germany, the United Kingdom, France, and Japan for the milled fiber, and Japan and the United Kingdom for short fiber. In all, Canada exported to more than 70 countries in 1973.

By 1990, among importers of Canadian asbestos, the United States had dropped to second, behind Japan, for the crude fiber (as U.S. imports were 13 percent of 1,469 t), to seventeenth for the milled fiber ( 8 percent of 378,000 t), and to second, behind Japan, for the short fiber (14 percent of 270,000 t) (Morel-à-l'Huissier and Hoskin, 1992). In 1999, the United States was grouped with other countries for all but the crude fiber because of the low import tonnage (Perron, 2001). In 2003, major export markets for Canadian asbestos were, in decreasing order by tonnage, India, Thailand, the Republic of Korea, Japan, Algeria, Mexico, and Malaysia. Thus, Asian markets were relatively small in the 1970s but grew in dominance as markets shifted away from the United States and European countries in the 1980s. A detailed account of all exports from Canada is beyond the scope of this Circular; the "Canadian Minerals Yearbook" chapters on asbestos contain such information (Perron, 2001, 2003).

\section{Other Market-Economy Countries}

\section{Brazil}

Brazil is a relative newcomer in the asbestos industry. Although small amounts of asbestos were mined as early as 1932, it wasn't until 1967 that Brazil began significant production of chrysotile (Harben, 1984). Even then, production was only 16,300 $\mathrm{t}$ in 1970 (table 4). In 1971, the industry received a boost because of the Brazilian Goals and Bases Program. About \$9.2 million was invested by the government to increase production (Clifton, 1973). Within 10 years, production was almost 170,000 t. Production peaked in 1991 at 237,000 t. Following a decline to about $170,000 \mathrm{t}$ in 1995 , production increased to about 194,000 $\mathrm{t}$ in 2002 and 2003. Markets in Brazil were primarily those dealing with the manufacturing of asbestos-cement products ( 85 percent of sales for the dominant Brazilian producer) and friction products, including brakes and clutches (O’Driscoll, 1989, p. 34; Kendall, 1996, p. 49).

Export of asbestos began from Brazil in about 1980. In 1986, the major destinations for the largest Brazilian asbestos producer were Argentina, India, and Mexico, and smaller shipments were made to China, Japan, Portugal, and Spain (Roskill Information Services, Ltd., 1986, p. 14). By 1987, exports accounted for 25 to 30 percent of sales, and in the late 1980s, major destinations for exported fiber included Africa, Asia, island nations in the Caribbean, and Latin America (O'Driscoll, 1989, p. 34). In 2003, major export markets were, in decreasing order by tonnage, Thailand, India, Iran, Indonesia, and Mexico (UN Statistics Division, 2005).

\section{Cyprus}

Cyprus was a small producer of chrysotile and thus is included under other countries in table 4. Although mention of asbestos products appears in early Greek history, systematic mining of small amounts of asbestos in Cyprus did not occur until around 1907 (Becker \& Haag, 1928, p. 39; Howling, 1937 , p. 48). Significant commercial production did not begin until about 1950. Before that time, production was less than $15,000 \mathrm{t} / \mathrm{yr}$, and that amount was attained only in the late 
1940s. World War II affected production drastically because Cyprus had an export-oriented asbestos industry. The industry recovered after the war. Within 25 years, production peaked at about 38,000 t in 1976 (Maliotis and Ilich, 1986). From there, a rapid decline occurred and production ceased around 1988.

Exports were the key to the asbestos industry's survival in Cyprus. In 1962, about 69 percent of production was exported (May, 1964). By 1980, exports had reached 86 percent of production (table A8). Like Greece and Italy, Cyprus exported asbestos to Europe (Belgium and Luxembourg, Czechoslovakia, Denmark, France, Germany, Greece, Ireland, and the United Kingdom), Africa (Egypt), and Asia and the Middle East (India, Indonesia, Japan, Syria, Taiwan, and Thailand) (Roskill Information Services Ltd., 1990, p. A4). The bulk of the exported asbestos was used by the asbestos-cement industry (Virta, 1987).

\section{Greece}

The earliest report of asbestos production in Greece was by Strabo in the 1st century A.D., and later reports were made by Solinus and Plutarch. They indicated that the fiber was carded and woven into handkerchiefs (Evans, 1906). Despite this early start, large-scale production of asbestos (mainly chrysotile) in Greece did not begin until the 20th century, and even then, production was sporadic.

Significant asbestos production in Greece did not begin until the early 1980s (table 4) as production declined in other parts of the world. In 1981, a new mill and mine near Zidani were opened. Production progressed slowly as technical difficulties were encountered and the world asbestos markets were soft (Sassos, 1983). Production increased to 66,000 t in 1990 from 17,000 $\mathrm{t}$ in 1982 (table 4). In 1991, the mining operation had one of several financial problems, resulting in a drastic downturn in production. In 1992, the company began operating again under new management (Skillen, 1993, p. 37). Production in Greece peaked at 80,200 $\mathrm{t}$ in 1996. Mining ceased in 1998, although fiber recovery from stockpiles and sales from stocks may have continued through 2001.

When the Zidani mine opened, the largest planned market was in asbestos-cement products. About 10 percent of the mine's output was to be used in other products such as floor tiles, asbestos paper products, putties, and paints (Industrial Minerals, 1978). In 1980, 20 to 25 percent of production was used domestically (Clifton, 1981). By 1993, 95 percent of the fiber was exported to Europe, the Far East, the Middle East, and Brazil, predominantly for asbestos-cement and roofing applications (Skillen, 1993, p. 37). Around 1978, Greece was importing about 30,000 t/yr of asbestos for its own asbestoscement industry (Industrial Minerals, 1978).

\section{Italy}

Italy was the second largest producer of asbestos in Europe, behind Russia, for most of the 20th century. Italy was surpassed by Greece in 1989 only with the shutdown of the Italian asbestos industry. Systematic production of Italian deposits began in the middle of the 19th century, although manufacturing had been reported earlier (Howling, 1937, p. 59; Alleman and Mossman, 1997). Production remained below 10,000 t until 1941 (table 4). Prior to the discovery of the Canadian deposits in the late 1800s, Italy supplied much of the world's asbestos needs (Bowles, 1934, p. 19; Howling, 1937, p. 59). Most of that early production was tremolite. After World War I, the Balangero mine near San Vittore opened, and production of chrysotile comparable to Canadian fiber increased (Howling, 1937, p. 62). After a brief decline during World War II, production increased steadily. Around 1968 , the only operating mine in Italy upgraded its facilities to increase production (Icke, 1969). Asbestos production peaked at $165,000 \mathrm{t}$ in 1976 and ceased in 1991. The Italian industry collapsed after the passage of government legislation banning the use of asbestos (Loughbrough, 1992, p. 43). Markets for Italian fiber included adhesives, asbestos-cement products, bitumen, electrical insulation, friction products, jointings, paper, and plastics (Mining Magazine, 1987). In 1985, it was estimated that about 70 percent of domestic sales were for asbestos-cement applications (Craynon, 1988, p. 482).

Italy had an active asbestos-manufacturing industry and thus exported less than half of its asbestos production. Exports of $63,818 \mathrm{t}$ accounted for about 40 percent of production in 1980; the remainder was used domestically in asbestos-cement products (Roskill Information Services Ltd., 1983, p. 45). In 1985 , Italy's asbestos exports were estimated to be 66,200 $\mathrm{t}$; the leading importers of Italian fiber were West Germany $(15,400 \mathrm{t})$, France $(10,000 \mathrm{t})$, and Japan (7,130 t) (Craynon, 1988 , p. 470). Italy imported crude fiber, requiring 41,400 t in 1984 (Sondermayer, 1987, p. 486).

\section{South Africa}

South Africa was probably the second most important market-economy producer of asbestos from about 1950 through the mid-1980s. Asbestos production in South Africa began in the late 1800 s but had progressed to only a few hundred tons by the start of the 20th century (table 4). Production increased slowly from 1900 to about 25,000 t in the 1940 s after a mild downturn in the 1930s.

After World War II, production increased rapidly, undoubtedly aided by major rebuilding efforts worldwide and growing economies starting in the 1950s. The number of mills in the Transvaal area increased from 6 to 27 in 1948-1949, allowing for increased fiber production (South African Mining Journal, 1949). Mining increased from 41,500 t in 1948 to its peak of 380,000 $\mathrm{t}$ in 1977 with only minor setbacks (table 4). Around 1956, the amosite and crocidolite producers resolved problems with mine pumping and ventilation, although these problems didn't appear to affect production significantly (Kennedy and Mattila, 1958). Chrysotile production capacity received a boost with the completion of a new mill near Barberton in 1969 (Readling, 1971). As awareness of the 
asbestos health issue increased in the early 1970s, sales began to decline and, by 1977, producers were reporting higher than expected stocks, indicating that production was outpacing demand (Clifton, 1980a). After peaking in 1977, production declined rapidly to $135,000 \mathrm{t}$ in $1987,50,000 \mathrm{t}$ in 1997 , and $6,220 \mathrm{t}$ in 2003.

South Africa was unique in that it was the major world supplier for amosite and crocidolite and also produced chrysotile and minor amounts of anthophyllite and tremolite. Production of amosite, crocidolite, and chrysotile each dominated a different time period: amosite between 1938 and 1955, crocidolite from 1956 through 1982, and chrysotile prior to 1938 and after 1982. Production histories differed for the different types of asbestos as summarized below:

- Amosite. South African amosite was first mined in the Barberton District in 1907 and in the Pietersburg District in 1914 (Becker \& Haag, 1928, p. 30; Kupferburger, 1930). Amosite accounted for the largest share of production between 1938 and 1955. Following an expansion program begun in 1948, amosite production increased through 1973, when it peaked at 106,000 t (Howling, 1937, p. 36; Bowles, 1959, p. 31; van der Merwe, 1989; Roskill Information Services Ltd., 1990, p. 43). Demand for amosite began to decline in the early 1970s, in response to health concerns. Amosite mining ceased around 1992, although stocks were sold after that time (Mining Journal, 1992; Industrial Minerals, 1993; British Geological Survey, 1995, p. 24).

- Crocidolite. Crocidolite production in South Africa was reported as early as 1893 (Diller, 1921, p. 555; Becker \& Haag, 1928, p. 29; Munzhelele, 2000). Crocidolite production in South Africa peaked in 1977 at 201,000 t and dominated from 1956 through 1982 (Howling, 1937, p. 36; Bowles, 1959, p. 31; van der Merwe, 1989; Roskill Information Services Ltd., 1990, p. 43). Demand for crocidolite began to decline in the late 1970s. Crocidolite mining ended in 1997 (Munzhelele, 2000; British Geological Survey, 2002, p. 25).

- Chrysotile. Chrysotile, whose production in South Africa began in 1905, was produced in small amounts in the country's early mining history, with production being less than 1,000 t/yr before 1949 (Becker \& Haag, 1928, p. 30; Bowles, 1959, p. 31). Chrysotile accounted for the largest share of asbestos production in South Africa prior to 1938 and after 1982, as amosite and crocidolite production declined in the early 1970s and late 1970s, respectively, in response to health concerns. Chrysotile production peaked in 1989 at about 115,000 $\mathrm{t}$ and was 6,000 $\mathrm{t}$ in 2003 (Howling, 1937, p. 36; Bowles, 1959, p. 31; van der Merwe, 1989; Roskill Information Services Ltd., 1990, p. 43; USGS, 1997-2005).

- Anthophyllite and tremolite. Only small amounts of anthophyllite and tremolite were produced in South Africa, generally on the order of only a few thousand tons annually, combined.
Like Canada, South Africa has been a net exporter of asbestos. More than 75 percent of South African production after 1960 was exported annually (Gössling, 1977, p. 75; Munzhelele, 2000). For most years, exports were between 85 and 95 percent of production (although some of this amount was probably shipped from stocks during some years). Exports went to the Far Eastern countries, Middle Eastern countries, and European markets. Between 1935 and 1955, the United Kingdom and United States were the largest importers of fiber from South Africa (Bowles, 1959, p. 44). These two countries accounted for 27 percent and 23 percent of exports, respectively, in 1954 (Bowles, 1959, p. 44). These countries were followed by various other European countries, Australia, Japan, India and Pakistan, and various Latin American countries in 1954 (Bowles, 1959, p. 44). Total exports from South Africa were 21,500 t in 1935 and 116,000 $\mathrm{t}$ in 1954.

By 1970, major importers of South African asbestos were Japan (33 percent), Italy (11.7 percent), the United Kingdom (9.5 percent), Germany (9.3 percent), and France (6 percent) (Gössling, 1977). Only 3 years later, these export markets had changed to Japan (33.7 percent), Spain (15.2 percent), Italy (9.4 percent), the United Kingdom (7.8 percent), Germany (5.8 percent), France (5.6 percent), and the United States (5.6 percent) (Gössling, 1977, p. 74). These same countries continued to be major markets as late as 1985 . Other historical destinations included Austria, Belgium, Denmark, Taiwan, and Yugoslavia (Gössling, 1977, p. 74). South African exports peaked around 1975 at 339,000 t, compared to a peak of 1.69 Mt in 1973 for Canadian exports (van der Merwe, 1989, p. 144; Louis Perron, written commun., 2001).

Like exporters elsewhere, South Africa was affected by asbestos health issues (van der Merwe, 1989). Partial or total bans on asbestos use in several European countries in recent years eliminated some former markets for the South African producers. Smaller losses in markets occurred with the downturn of the U.S. market after 1970. The major export market for South Africa in 2003 was Thailand (UN Statistics Division, 2005).

\section{Swaziland}

Swaziland was a relatively small producer of chrysotile. Except for some sporadic mining, commercial production didn't really begin until 1939, when production was reported to be about 7,000 $\mathrm{t}$ (table 4). That was the year that the Havelock mine began operating (Bowles and Warner, 1940). Within 3 years, production had surpassed 20,000 t/yr. Installation of an aerial ropeway through to the rail lines in 1941 eased a major transportation problem (Bowles and Petron, 1943). Over the next 35 years, demand rose slowly and was interrupted by brief periods of downturns. For a short period in the early 1970s, production suffered because of problems with rock stability in one of the underground mines (Clifton, 1975). Production peaked in 1976 at 41,800 t. Production declined to $12,700 \mathrm{t}$ in 2000 , when production ceased. 
Like the other asbestos-producing countries in Africa, Swaziland depended on exports to sustain its industries. The bulk of the production was shipped to other African nations, Europe, and the Far East. Most of the asbestos was used to produce asbestos-cement products. Shorter fibers were used for friction applications (Roskill Information Services Ltd., 1990, p. 48).

\section{Zimbabwe}

Zimbabwe is renowned for its production of low-iron, long-fiber chrysotile. Mining began around 1908 (Becker \& Haag, 1928, p. 35; Natural Resources Board of Southern Rhodesia, 1963). By 1930, Zimbabwe produced 34,000 t of asbestos and was the third largest producer after Canada and the combined production of Kazakhstan and Russia (table 4). The opening of the Shabanie Railway in 1927 helped spur production by eliminating a major transportation issue (Bowles and Stoddard, 1930). Competition from Russia affected Zimbabwean producers in the early 1930s, although this potential problem was resolved by European customers apportioning orders between the two sources (Bowles and Stoddard, 1933). Production began increasing by the mid-1930s. Much of the increase was attributed to increased sales of short chrysotile fiber grades used by the asbestos-cement industry (Bowles and Cornthwaite, 1937).

Despite growing sales, Zimbabwe lost its third place standing to South Africa by 1950 but regained it in 1985 when markets for South Africa's amphibole asbestos declined. Between those times, Zimbabwe declared its independence from the United Kingdom in 1965 and had UN economic sanctions imposed in 1966. Despite the sanctions from 1966 to 1979 and strikes in 1972, the companies continued to upgrade their production facilities, and production and sales increased (British Sulphur Corporation, 1972, p. 3; Clifton, 1974, 1982; Clarke, 1982). Production peaked at 281,000 t in 1976 (table 4). However, market reversals resulted in a decline in sales and buildup of large stocks between 1978 and 1980 (Roskill Information Services Ltd., 1983, p. 68). Production declined to $115,000 \mathrm{t}$ in 1999 but then rebounded to about 147,000 $\mathrm{t}$ in 2003 (table 4).

Like South Africa, Zimbabwe depended on export markets to sustain its asbestos industry. About 97 percent of its production was exported to 50 countries by the early 1980 s (Clarke, 1982). The United Kingdom was the leading importer from 1935 to 1956 except during World War II, when the United States became the leading importer of Zimbabwean fiber. Other important markets were other European countries and Australia, India, and Latin America (Bowles, 1959, p. 43). In 1980, Southeast Asia was a major market for Zimbabwean fiber because of its use in textiles (Industrial Minerals, 1980). In 1982, it was estimated that Zimbabwe supplied about 50 percent of the world's asbestos fiber for textiles (Clarke, 1982). Another market for the fiber was in asbestos-cement products (Roskill Information Services Ltd., 1983, p. 68). In 2003, major export markets, in decreasing order by tonnage, were Slovakia, Thailand, India, Iran, Brazil, and Japan (UN Statistics Division, 2005).

\section{Countries Currently or Formerly Having Centrally Planned Economies}

\section{China}

Production of asbestos (mainly chrysotile) in China is difficult to track over time. As with many of the industrial minerals mining industries in China, accurate production and trade data on asbestos are difficult to obtain and frequently are not available. The use of asbestos in China began more than 2,000 years ago, when asbestos was used to make fire insulation, asbestos paper, and fire pots (by mixing lime with asbestos). The most famous and earliest source for asbestos mined in China was Szechuan Province (Wang, 1981, p. 256). Production by individual companies operating in China between 1918 and 1928 was reported to be less than $100 \mathrm{t} / \mathrm{yr}$ combined (Becker \& Haag, 1928, p. 44). Around 1934, production was estimated to be less than a few hundred tons (Bowles, 1934, p. 22).

China became a moderate-sized producer of asbestos around 1960, when production was estimated to be $81,600 \mathrm{t}$ (table 4). By 1965, 10 new asbestos projects were believed to have been completed in Szechuan Province, after which asbestos production increased fairly rapidly (Wang, 1967, p. 1115-1116). Production was reported to be $209,000 \mathrm{t}$ in 1973. More than 12 up-to-date facilities mining and processing asbestos were online in Szechuan Province by 1975. By that time, Hopeh (Hebei) Province became the second largest producing region in China (Wang, 1978, p. 297-298). Production declined in the mid-1970s and early to mid-1980s. It was about 221,000 $\mathrm{t}$ in 1990. Production increased to $350,000 \mathrm{t}$ in 2003 (table 4). Because world markets declined between 1990 and 2003, the increase in Chinese asbestos production probably was used within the country. Market data in China are not routinely published, but in 1985, it was reported that asbestoscement products accounted for 51 percent of the asbestos usage in China (Chin, 1988, p. 216). Asbestos-cement markets still dominated in 1996, followed by friction products, rubber, textiles, and insulation products (Lu, 1998).

China consumed most of its production internally and cannot be considered a world supplier of asbestos. Exports were mostly to Southeast Asian markets. In 1964, exports were only a few thousand tons, with most exported to Japan and Poland (Wang, 1967, p. 1116). Asbestos exports were reported to be only 1,394 t in 1974; all went to Japan. Exports were 10,430 t in 1979 (Chin, 1983, p. 233). Exports in 1980 (7,397 t) were shipped mainly to Hong Kong, Indonesia, and Thailand (Chin, 1983, p. 233). Despite increased production, exports fell to $553 \mathrm{t}$ in 1986 . Hong Kong, Singapore, and Thailand were the major destinations in 1986 (Chin and Wu, 1990, p. 240). Exports were reported as 9,392 $\mathrm{t}$ in 1996, with Vietnam being the leading importer of Chinese asbestos $(7,763$ 
t) (Lu, 1998). In 2003, exports were only 3,470 t (table A19), and North Korea and Thailand were the leading destinations (UN Statistics Division, 2005).

Imports generally were not reported or import data were not available over much of the history of the asbestos industry in China. Imports were reported to be $179 \mathrm{t}$ in 1973 and $839 \mathrm{t}$ in 1985 (Wang, 1978, p. 291; Chin, 1988, p. 207). By the 1990s, imports had increased, rising from 1,083 $\mathrm{t}$ in 1990 (table A10) to 77,959 t in 1996 (table A12). Of significance was the increased importation of long-fiber asbestos. The major source for imported asbestos in 1996 was Russia (77,091 t) (Lu, 1998, p. 19). China imported 145,000 t in 2003 (table A19), and 119,000 t (82 percent) were supplied by Russia (UN Statistics Division, 2005).

\section{Kazakhstan and Russia}

Asbestos has been produced in Kazakhstan since the 1960s and in Russia since the late 1800s. These countries are discussed together in this Circular because production data were generally available only for the Soviet Union prior to its dissolution in 1991.

Sinclair $(1959$, p. 3) reported that deposits in the Ural Mountains were first opened around 1720 and that systematic mining of chrysotile on a commercial scale began in the early 1800s (Becker \& Haag, 1928, p. 27; Howling, 1937, p. 62). Production in Russia was initially concentrated in Bajenova in the Ural district, which provided about 85 percent of the supply by the 1920s (Bowles and Stoddard, 1931; RuKeyser, 1933a). Production, however, essentially stopped with federalization of the mines in 1918, World War I, the Russian revolution, and establishment of the Soviet State following the war (Bowles and Stoddard, 1930; Howling, 1937, p. 62).

Completion of a rail line that connected to the TransSiberian Railway in 1927 greatly improved access to the Uralasbest chrysotile deposit and made possible intensive development of the mines (RuKeyser, 1933b). By 1927, Russia provided 11 to 15 percent of the world's supply of asbestos. A new line replaced this rail line in 1931. The new line improved efficiency because it conformed to the standard Russian gauge, eliminating the need to transfer equipment and product at the railhead (RuKeyser, 1933b).

In the 1930s, Russia began to develop a large asbestos products industry, making Russia both a major asbestos producer and a major consumer, and thereby reducing its dependence on foreign markets (Bowles and Stoddard, 1933). Bowles (1934, p. 18) noted that exports declined from 51 percent in 1922-1923 to 21 percent in 1934, reflecting the rapidly expanding domestic manufacturing industry. Around 1937, a 5-year plan (one of many) was developed that would increase capacity to 220,000 t/yr (Bowles and Barsigian, 1943). Production increased gradually through 1982, except perhaps for World War II, for which data were not available. Contributing to the increase of production in the Soviet Union was the development of the Tuva asbestos complex in the Tuva Autonomous Republic of Russia in 1964 and the Dzhetygara chrysotile deposit in Kustanay Oblast in Kazakhstan in 1965 (Roskill Information Services Ltd., 1990, p. 57).

By 1975, Kazakhstan and Russia, combined, had surpassed Canada as the world's leading producer of asbestos (table 4). Production in the Ural Mountains of Russia accounted for about 73 percent of asbestos production, followed by Kazakhstan with 24 percent and the Tuva Republic with 3 percent (Sutulov, 1973, p. 176).

The Kiyembay asbestos combine in the Orenburg Oblast of Russia began operating in 1979 and reached full operating capacity in 1985 (Strishkov, 1981b, p. 997; Industrial Minerals, 1985). In 1979, the Uralasbest combine accounted for more than 62 percent of Soviet production; the combines in Kazakhstan, Orenburg, and Tuva accounted for 26, 10.5, and 1.2 percent of Soviet production, respectively (Strishkov, 1981b, p. 996). Uralasbest, however, continued to provide all of the asbestos exported in 1980 (Clifton, 1982, p. 110).

The combined production of Kazakhstan and Russia continued to increase until 1982, when it peaked at about $2.7 \mathrm{Mt}$ (table 4). By then, the health issue had begun to affect some of the export markets. A more serious issue for producers in Kazakhstan and Russia was the breakup of the Soviet Union in 1991. Combined production for Kazakhstan and Russia declined from $2 \mathrm{Mt}$ in 1991 to 744,000 $\mathrm{t}$ in 1996 (table 4). Many industries, not just the asbestos industry, were affected by financial difficulties immediately after the breakup. Markets, however, recovered for the asbestos producers, and the combined production in Kazakhstan and Russia rebounded to 1.230 Mt in 2003, accounting for 55 percent of world asbestos production. Between 1992 and 2003, Kazakhstan accounted for 21 percent of production in the former Soviet Union (USBM, 1933-1996; USGS, 1997-2005).

In the early 1960s, more than 80 percent of asbestos consumed in the Soviet Union was used in roof tiles, wall panels, pipes, molded articles, and other building materials. Lower grades were used in manufacturing heat insulations and heat-resistant plastics. Treated mill wastes were used to make reinforced asphalt and roofing paper, filler in portland cement for concrete pipe, plaster, and protective coatings for metallic structures. Untreated asbestos mill wastes were used as railroad ballast and cold asphalt (Tverskoi, 1968). By about 1967, major markets were roof tiles, wall panels, pipes, heat insulations, asphalt, roofing paper, asbestos-cement products, and plasters (Tverskoi, 1968). Asbestos-cement products were the dominant market in some recent years.

The former Soviet Union eventually became a major participant in the world asbestos economy because its production in Kazakhstan and Russia exceeded its domestic needs. In its early history, a significant percentage of production was exported. However, Bowles and Stoddard (1933, p. 751-752) observed that the asbestos-manufacturing industry in the Soviet Union was expanding rapidly in the 1930s and consuming a larger share of domestic production. By 1961, exports from the Soviet Union were 176,800 t (Sokoloff, 1964, p. 760). The bulk of the exports went to Eastern and Western Europe and Japan $(8,800$ t); the importing European coun- 
tries, listed in order of decreasing tonnage, were as follows: West Germany (27,500 t), France (25,500 t), East Germany (14,000 t), Czechoslovakia (12,700 t), Bulgaria (12,000 t), Poland (11,300 t), and Hungary (10,100 t) (Sokoloff, 1964, p. 760). Exports expanded rapidly after that, reaching 385,000 $\mathrm{t}$ in 1970 (Strishkov, 1973, p. 832). In 1968, Tverskoi (1968) reported that the Soviet Union exported asbestos fiber to more than 30 countries. By 1970, export destinations, listed in order of decreasing tonnage, were as follows: France $(53,000 \mathrm{t})$, Japan (43,900 t), West Germany (43,100 t), Poland (31,500 t), Bulgaria (21,200 t), Czechoslovakia (21,100 t), Yugoslavia (20,600 t), and Romania (16,300 t) (Strishkov, 1973, p. 832). Exports increased to 613,000 t in 1975 (Strishkov, 1980, p. 1085).

There was a major unexplained decline in exports in 1976, when exports were only 389,000 t compared to 613,000 $\mathrm{t}$ in 1975 (Strishkov, 1981a, p. 982). Exports recovered by 1980, when they were reported to be 600,000 t (table A8). In the early 1980 s, countries having centrally planned economies accounted for about 50 percent of exports from Kazakhstan and Russia (Roskill Information Services Ltd., 1983, p. 64). Declining asbestos consumption worldwide and possibly internal issues resulted in export declines to 310,000 $\mathrm{t}$ in 1985 (table A9) and to 248,000 t in 1990 (table A10). By 2000, export markets had improved, and exports from Kazakhstan and Russia were 495,000 t (tables A10-A16).

In 2003, exports from Kazakhstan were estimated to be 184,000 t (table A19). Major markets, in decreasing order by tonnage, were Ukraine, Uzbekistan, India, Kyrgyzstan, and China (UN Statistics Division, 2005); these countries accounted for 90 percent of exports from Kazakhstan. Exports from Russia in 2003 were 450,000 t (table A19). Major export destinations, in decreasing order by tonnage, were China, Ukraine, India, Iran, Vietnam, and Thailand; these countries accounted for 84 percent of Russian exports (UN Statistics Division, 2005).

\section{Other Producing Countries}

While the above-mentioned countries produced the bulk of the asbestos, many other countries produced small amounts of asbestos that filled essential markets. For example, Finland was the world's primary source for anthophyllite asbestos from about 1919 to 1975 . Production in Finland was relatively low over time, exceeding 10,000 t/yr for only a few years in the late 1960s (USBM, 1933-1996). After that, production declined and finally stopped in 1975.

Crocidolite was produced in Australia and Bolivia. Australia began producing asbestos around 1916 (table 4). Production increased slowly to $16,700 \mathrm{t}$ in 1962 . It declined rapidly to $666 \mathrm{t}$ in 1967 after Australian Blue Asbestos Pty. closed its Wittenoom mine in 1966 (Morrell, 1969, p. 99). Production increased in the early 1970 s to meet world demand, peaking at $92,400 \mathrm{t}$ in 1980. No production, however, was reported after
1983 (table 4). Bolivia produced only $1 \mathrm{t}$ of crocidolite in 1968 (Clifton, 1972, p. 201).

India was a source for anthophyllite and tremolite asbestos, as well as chrysotile. Production began around 1917 and eventually reached 44,100 $\mathrm{t}$ in 1993 (USGS, 1901-1926; USBM, 1927-1933, 1933-1996). Production was estimated to be about 19,000 $t$ in 2003 (table A19).

Japan and the Republic of Korea also were important sources of mainly chrysotile for Far Eastern asbestos markets during various periods of the 20th century. Production in Japan began by 1920 , peaked at 27,000 $\mathrm{t}$ in 1967, and finally ceased in 2000 (USGS, 1901-1926, 1997-2005; USBM, 1927-1933, 1933-1996). Production in the Republic of Korea began in the early 1930s. Its production peaked at 15,900 t in 1982. Production was last reported in 1992.

A host of other countries also provided even smaller amounts (less than 5,000 t each) of asbestos for domestic or export markets.

\section{World Consumption}

\section{Introduction}

The following section includes a description of asbestos consumption in the United States and the following groups: other countries in Central and North America, Europe, Asia and the Middle East, Africa, South America, and Oceania. For consistency, data used in this section were extracted from publications of the British Geological Survey and its predecessors and the United Nations Statistics Division (2005) trade data. Production data used in the above section on "World Supply, Demand, and Trade" were from U.S. Bureau of Mines and U.S. Geological Survey "Mineral Resources of the United States" and "Minerals Yearbook" (USGS, 1901-1926, 1997-2005; USBM, 1927-1933, 1933-1996). See the section "Data Sources" for further explanation.

World consumption patterns for asbestos have evolved over time. Changes have occurred because of technological progress (industrialization and the development of an asbestosmanufacturing industry), availability of asbestos either domestically or through imports, political changes (civil unrest, independence movements, or sanctions), regulatory bans on its use, world conflicts, liability issues, and, foremost in recent years, health issues. By tracking apparent consumption, one can obtain a general idea of the changes that have occurred in the worldwide use of asbestos over time.

Apparent consumption for this Circular is defined as production plus imports minus exports; where possible, the values were adjusted to account for changes in government and industry stocks. Bowles (1955, p. 59, 1959, p. 32) noted that it is much more difficult to determine apparent consumption than production. What applied in the 1950s is still true today. Manufacturing from consumer stocks, sales from producer stocks, and a lack of data on amounts of consumer and producer stocks 
that have been held over from year to year complicate the estimation of apparent consumption, as do the limitations of the data as discussed in the "Data Sources" section.

Overcapacity, particularly after the asbestos health issue was raised, resulted in a significant share of production going into stocks for some countries in some years. This accumulation of stocks had a relatively minor effect on apparent consumption calculations for nonproducing countries. It did have an effect on apparent consumption calculations for Canada, South Africa, and Zimbabwe, which were leading producers with relatively small asbestos-product-manufacturing industries. Although calculated apparent consumption for these countries may have been large some years, actual consumption was much less because of indeterminate amounts of asbestos production being placed in stocks. These changes in stocks, as well as incomplete trade reporting, resulted in significant incongruities in asbestos production, trade balance, and apparent consumption calculations between 1998 and 2000, as was noted in USGS Open-File Report 03-083 (Virta, 2003b). More recently available data used for the calculation of apparent consumption for 1998 through 2003 appear to have resolved this imbalance issue, as world production and world consumption estimates are similar. Still, the following discussion should be viewed as an approximate measure of apparent consumption and should be utilized to determine trends in the apparent consumption of asbestos rather than its absolute consumption. A detailed breakout of calculated apparent consumption by country is given in the appendix for specific times: for 1920-1970, at 10-year intervals (tables A1-A6); for 1970-1995 at 5-year intervals (tables A6-A11); and for 1996-2003, at 1-year intervals (tables A12-A19).

\section{United States}

Although the modern asbestos industry first began in Asia and Europe, it was the United States that fully embraced its potential, becoming the largest consuming country in the world for much of the 20th century (figs. 1 and 2). The United States offered the greatest opportunities for the relatively new asbestos industry. The country's population centers were expanding rapidly with the surge in immigration in the early 1900s; capital was available for investment in the asbestos industry; there were large demands for construction of housing, public buildings, and roads; and Canada could provide a ready supply of asbestos. To meet these demands, the construction industry not only expanded but also evolved through technological developments, creating an opportunity for the asbestos industry to establish itself. Thus, the use of asbestos exploded in the United States unlike anywhere else in the world. The United States became a world leader in usage within a couple of decades of having begun its asbestos industry and held that position through the 1960s.

From 1920 through the 1960s, the United States accounted for 30 to 83 percent of world apparent consumption for the 10-year intervals examined. In the late 1960s, the
United States was replaced by the Soviet Union as the leading consuming country (fig. 2). The next nearest competitor was Japan, which had attained a consumption of 319,000 $t$ in 1970 (table A6). A detailed discussion of U.S. consumption of asbestos is presented above in the section "World Supply, Demand, and Trade."

\section{Other Countries in Central and North America}

Other countries in Central and North America consumed relatively small amounts of asbestos. These included Canada, Costa Rica, Cuba, the Dominican Republic, El Salvador, Guatemala, Honduras, Jamaica, Mexico, Nicaragua, and Panama. Most of these countries were small consumers, using only a few thousand tons annually.

Canada was primarily an exporter but its calculated apparent consumption was 106,000 $\mathrm{t}$ of asbestos in 1980 (table A8). Canada probably had an oversupply as world markets began to decline. A large part of the 106,000 t probably went into stocks rather than Canadian commerce. Consumption of around 45,000 $t$ annually probably would have been the norm from 1940 to 1970 and much less after the 1980s.

Consumption in Mexico gradually built up to 79,000 t in 1980 from an annual consumption of only $390 \mathrm{t}$ in 1930 (tables A2 and A8). After 1980, consumption declined, eventually reaching 20,000 $\mathrm{t}$ in 2003 (table A19).

In 2003, Cuba, the Dominican Republic, El Salvador, Guatemala, and Panama were other Central and North American countries consuming asbestos. Only Cuba and El Salvador increased their consumption of asbestos between the late 1990s and 2003.

\section{Europe}

After the United States, Europe was the next region to develop an asbestos-manufacturing industry. The United Kingdom, receiving its asbestos from other parts of its world empire, was the major European consumer during the early part of the 20th century (fig. 2, table A1). Many other European countries soon followed the United Kingdom. By 1930, Belgium and Luxembourg, Germany, and the United Kingdom were major suppliers of asbestos products throughout Asia and Europe. The former Soviet Union was the next largest producer and consumer of asbestos with its need to supply itself and other countries having centrally planned economies. Apparent consumption in the Soviet Union exceeded that of the United Kingdom by 1950 and that of the United States by 1970 because of large construction demands.

There were 17 European countries consuming a total of 40,900 $\mathrm{t}$ of asbestos in 1920 (table A1). By 1930, estimated consumption had increased to 127,500 $\mathrm{t}$ (table A2). Belgium and Luxembourg, Czechoslovakia, France, Germany, Italy, the Soviet Union, and the United Kingdom experienced the largest growth in consumption between 1940 and 1950 (tables A3 and A4). Between 1950 and 1960, the asbestos industry 
in Europe experienced its greatest expansion up to this time, increasing to $1.17 \mathrm{Mt}$ (table A5) from 507,000 $\mathrm{t}$ in 1950. During the decade of the 1950s, consumption in Austria, Belgium and Luxembourg, Czechoslovakia, Denmark, France, Italy, the Netherlands, Poland, the Soviet Union, Spain, Sweden, Switzerland, the United Kingdom, West Germany, and Yugoslavia increased considerably. The largest gains were in the Soviet Union $(317,000 \mathrm{t})$, the United Kingdom $(55,400 \mathrm{t})$, and West Germany $(52,400 \mathrm{t})$. Much of the growth in consumption in the late 1940s and a large portion of the 1950s can be attributed to the massive reconstruction efforts in Europe following World War II. Estimated consumption in Europe increased to 1.8 Mt in 1970 and 2.8 Mt in 1980 (tables A6 and A8). The largest growth was in the Soviet Union, increasing by slightly more than 1 Mt between 1960 and 1980.

The asbestos health issue, which affected U.S. markets by the mid-1970s, also began to affect asbestos in Europe. After 1980, demand in all large consuming European countries, except the Soviet Union, began to decline (figs. 1 and 2). This pattern continued through 1990, with only the Soviet Union maintaining its consumption levels. In 1990, consumption in Europe was $2.58 \mathrm{Mt}$ (table A10).

Between 1990 and the end of 2003, the European asbestos manufacturing industry experienced many changes. During that time, the Soviet Union was restructured, and many European countries banned the use of asbestos; in 2005, the EU voted to ban the use of asbestos except for a few exemptions. From a tonnage standpoint, the restructuring of the Soviet Union had the biggest effect. By 1995, estimated consumption in Europe had declined to $927,000 \mathrm{t}$, and by 1998, to 682,000 t (tables A11 and A14). However, consumption increased after that to 704,000 $t$ in 2000 and 857,000 t in 2003 (tables A16 and A19). Kazakhstan and Ukraine accounted for much of the increase. The leading consumers of asbestos in Europe and the former Soviet Union in 2003 were Azerbaijan, Kazakhstan, Kyrgyzstan, Romania, Russia, Ukraine, and Uzbekistan (fig. 3, table A19).

\section{Asia and the Middle East}

Asia and the Middle East were combined in this Circular for statistical purposes. The lack of asbestos production and limited number of countries using asbestos in the Middle East did not warrant separate treatment.

Growth in the Asian and the Middle Eastern asbestosmanufacturing markets lagged behind growth of those markets in Europe and the United States. This difference can be partially attributed to less initial industrial development in most Asian and Middle Eastern countries in the early 20th century; cultural differences guiding infrastructure and technological development; government policies regarding industrial development; and fiscal constraints affecting the startup of new industries or importation of new products.

Very little asbestos was used in Asia and the Middle East in 1920, only 6,810 t by two consuming nations (table A1). It wasn't until the 1950s that a serious manufacturing industry developed (figs. 1 and 2). Estimated consumption in 1960 was $222,000 \mathrm{t}$ in 16 countries, a dramatic increase from only 25,400 t in 1950 (tables A4 and A5). China and Japan accounted for the bulk of this increase in consumption. Asbestos consumption in Asia and the Middle East increased to 669,000 t in 1970 (table A6) from 222,000 $t$ in 1960.

Again, China and Japan accounted for the largest increases in consumption. Smaller increases occurred in India, Iran, the Republic of Korea, Malaysia, Thailand, and Turkey. Japan was the most consistent leading user of asbestos in this region from 1920 to 1970 (fig. 2). Estimated consumption in Asia and the Middle East increased to $1.07 \mathrm{Mt}$ in 1980 (table A8). By this time, more countries in the region were manufacturing asbestos products, and considerable gains were made in China, India, Indonesia, Iran, Japan, the Republic of Korea, Malaysia, Saudi Arabia (a one-time occurrence), Taiwan, Thailand, and Turkey.

The early 1980s brought about a shift in manufacturing in Asia and the Middle East. Estimated consumption declined in China, Japan, Malaysia, Saudi Arabia, and Taiwan but increased in India, Indonesia, the Republic of Korea and Thailand (tables A8 and A9). There was an increase in consumption through 1995 to $1.26 \mathrm{Mt}$ from 976,000 t in 1990 (tables A10 and A11). China accounted for the bulk of the increase and was followed by, in decreasing order by tonnage, Thailand, Indonesia, the Republic of Korea, and Malaysia (fig. 3).

In 2003, China accounted for 46 percent of the apparent asbestos consumption in Asia and the Middle East, mainly to satisfy its own domestic needs. India was the next leading consumer with 18 percent of the market, followed by Thailand (12 percent) and Iran (7 percent). Indonesia, Japan, the Republic of Korea, and Vietnam were smaller but still significant users of asbestos (table A19). Sixteen other countries in Asia and the Middle East still maintained a small presence in the asbestos-manufacturing sector.

\section{Africa}

Consumption in Africa was rather low throughout most of the 20th century, peaking in the 1990s. Slow population growth, limitations on land amenable for development, slow dissemination of technological developments, government policies toward development, and fiscal constraints influenced the development of the asbestos industry in Africa. Even the asbestos-producing African nations, despite having manufacturing facilities, exported the bulk of their fiber production to foreign manufacturing markets.

Only a few African countries used asbestos in the 1920s. Estimated consumption was about 2,200 t in 1920 (table A1). Egypt, Madagascar, and Zimbabwe, and probably South Africa, had small manufacturing industries. This situation did not change significantly until the 1950s. In 1950, consumption had risen to about 9,600 t, excluding South Africa and Zimbabwe, which apparently exported a large amount of asbestos from stocks and had a net negative apparent consumption 
(table A4). Algeria, Congo (Kinshasa), Egypt, Morocco, and Swaziland were the largest consumers.

Estimated consumption in Africa increased to 90,300 $\mathrm{t}$ in 1970 from 28,600 t (excluding South Africa's negative calculated apparent consumption) in 1960 (tables A5 and A6). The largest increases in consumption in 1970 were for two countries that had no reported consumption in 1960: Nigeria, where consumption increased to 34,400 t, and Zambia, where consumption increased to $15,600 \mathrm{t}$. Nigerian and Zambian imports varied considerably over time, suggesting that asbestos was stockpiled during one year and used over several years.

After the 1970s, consumption in most countries in Africa began to decline. The notable exception was Algeria, whose consumption was erratic but still was $21,300 \mathrm{t}$ in $1980,17,400$ $\mathrm{t}$ in 1990, 7,610 $\mathrm{t}$ in 2000, and 10,756 $\mathrm{t}$ in 2003 (tables A8, A10, A16, and A19). In 2003, several other African countries had small manufacturing industries (table A19).

Consumption in South Africa and Zimbabwe is largely ignored in the above discussion on Africa. Stockpiling of asbestos during times of overcapacity resulted in excessively high values for calculated apparent consumption for South Africa in 1985 (table A9) and Zimbabwe in 2000 to 2002 (tables A16, A17, and A18). Conversely, large shipments from stocks during periods of high demand resulted in excessively large negative values for calculated apparent consumption in South Africa in 1960, 1980, and 1998 (tables A5, A8, and A14). Including these values would have resulted in incorrect interpretations of consumption for all of Africa during those years.

\section{South America}

The asbestos industry in South America did not begin to have significance in the world markets until the 1960s. Before that time, there was little asbestos production or consumption (fig. 1). What little production there was existed to fill niche markets rather than to meet growing world demands. Argentina, Brazil, Chile, Peru, Uruguay, and Venezuela were the major South American consumers of asbestos during the early part of the 20th century. In 1960, consumption in South America was about 38,100 t (table A5). Brazil had just begun production to supply its own markets, but South America was dependent on imports for about 65 percent of its fiber consumption.

By 1970, Argentina, Brazil, and Colombia had the most active of the asbestos-manufacturing industries in South America. Even at that, consumption was estimated to be only 99,200 t (table A6).

By the mid-1970s, though, Brazilian production had expanded to meet the country's demands, and Brazil soon became the dominant South American producer and consumer of asbestos (table A7). In 1980, Brazil accounted for about 73 percent of the continent's asbestos usage of 267,000 t (table A8). Brazil was followed by Colombia with 27,100 t, Argen- tina with 21,400 t, and Venezuela with 9,100 t. Ecuador, Peru, and Uruguay used lesser amounts.

With the onset of the asbestos health issue, consumption in most South American countries declined. Even that of Brazil declined to 78,400 $\mathrm{t}$ in 2003 from 173,000 $\mathrm{t}$ in 2000, although its exports of asbestos increased from 63,100 t in 2000 to 144,300 t in 2003 (tables A16 and A19).

\section{Oceania}

Oceania includes Australia and New Zealand and other nations in the region. Australia and New Zealand produced and consumed asbestos in the early part of the 20th century. Consumption rose gradually through the mid-1970s (fig. 1) and peaked at 85,700 $\mathrm{t}$ in 1975 (table A7). Australia accounted for 73,200 t of this total. With the asbestos health issue of the 1970s, production and consumption declined rapidly. By 1990, New Zealand had stopped using asbestos, and in 2003, Australia's estimated consumption was 19 t (tables A10 and A19).

\section{General Trends}

In general, economic, political, and social agendas, different philosophies on how to meet those agendas, and different asbestos resources available guided the development of the asbestos-manufacturing industry in any given country in terms of the size of its industry and the types of products manufactured. If countries required an asbestos industry to meet their expansion needs, then the industry developed. The growth was logical in that demand for asbestos products, most notably asbestos-cement products, was greatest in countries undergoing extensive infrastructure development.

Few historical data on asbestos markets are available. Even in the United States, an annual survey of consumption was not developed until 1972, although data were projected back in time to estimate values for 1965-1971 (table 3; Clifton, 1976). From the qualitative descriptions by Bowles (1937, p. 82-87) of the asbestos-manufacturing industries in major producing countries, one can infer that asbestos-cement corrugated and flat sheet, pipe, and roofing tile were the major markets for asbestos around 1930. The low cost of asbestoscement products, their durability and effectiveness, and the relatively unsophisticated technology required to produce asbestos-cement products were major factors leading to the widespread use of asbestos cement, particularly for developing countries with limited mineral and monetary resources. In regions where there were alternative construction materials, the demand for asbestos-cement products was proportionally smaller, and a much wider variety of other asbestos products were developed.

In 1980, asbestos-cement products accounted for approximately 66 percent of the world consumption of asbestos according to estimates by Roskill Information Services Ltd. (1983, p. 86). The United States and Western European coun- 
tries were less dependent on asbestos-cement products than other regions. In the United States, asbestos-cement products accounted for 18 percent of apparent consumption of asbestos in 1980 (table 3). Estimated asbestos-cement consumption as a percentage of total asbestos consumption in 1980 follows for each region: Africa, 80 percent; Asia, 77 percent; Eastern Europe, 76 percent; South America, 76 percent; Oceania, 60 percent; North America, including the United States, 45 percent; and Western Europe, 43 percent (Roskill Information Services Ltd., 1983, p. 85-86).

With the decline in the use of asbestos in the 1980s and 1990s, markets shifted even more to favor asbestos-cement products. In 2003, asbestos-cement products were thought to account for more than 85 percent of the world's consumption of asbestos (Moore, 2004, p. 59; Virta, 2005b, p. 16).

\section{Discussion}

Asbestos has had a long and, until the 1960s, illustrious role in modern society. Over the course of its history, asbestos has been used in thousands of products for a vast number of applications. These applications ranged from roofing shingles to water-supply lines to fire blankets to plastics fillers to medical packings (Rosato, 1959). It was used commonly by industry and the general public. A glance at almost any home repair book written before about 1955 will show that the home handyman used asbestos as just another tool (Cobb, 1948, p. 129-130). That it was so widely accepted is a tribute not only to its versatility, but also to a lack of knowledge about the risks posed by exposure to high levels of airborne asbestos dust.

The British first raised health concerns in the early part of the 20th century, but it was not until the late 1950s and early 1960s that a correlation between excess exposure to asbestos fibers and respiratory cancer diseases was established (Selikoff and Lee, 1978, p. 22-23, 31-32; Gross and Braun, 1984, p. 20-21; U.S. Department of Health and Human Services, 1992, p. 33-34). Thus, the asbestos health issue did not arise until asbestos had been used by society for a long period of time. Asbestos is not alone in this respect. The discovery of adverse health effects after a material has been used for decades or even centuries is not unusual. A few examples are arsenic, beryllium, lead, mercury, uranium, and some fertilizers and insecticides. Extended use before the recognition of adverse health risks was a natural result of the long latency period (10 to 40 years) for the development of asbestos-related cancers (Agency for Toxic Substances and Disease Registry, 2001, 2005).

With these concerns over the health risk, many ask why and how the asbestos industry developed in the first place and why it continues to operate. One has to consider the knowledge of health risks throughout history and the state of technological development. As mentioned above, the connection between excessive exposure and lung cancer was not firmly established until the late 1950s and early 1960s; the industry was more than 100 years old before the lung cancer and mesothelioma issues were fully recognized and addressed. Further complicating the matter were disagreements among health researchers over the health risks posed by excessive exposure to asbestos. Some researchers have suggested that chrysotile is not as carcinogenic as amphibole asbestos varieties (Ross, 1984, p. 51; Agency for Toxic Substances and Disease Registry, 2001; Hoskins, 2001).

There is evidence of non-occupational risks associated with exposure to amphibole asbestos. Health researchers reported the occurrence of asbestos disease in the general public in Libby, Montana, where vermiculite contaminated with amphibole asbestos was mined, and near some exfoliation plants that processed the vermiculite ore (Peipins and others, 2003; Agency for Toxic Substances and Disease Registry, 2005).

Natural occurrences of asbestos have become an issue in California. In the past 5 to 10 years, development has moved into areas of serpentinite outcrops. These outcrops contain veins of chrysotile and some tremolite asbestos. New residents are now concerned about the risk to themselves and their children. This concern has resulted in a massive effort to map potential asbestos-bearing rock outcrops in California and elsewhere and to analyze the health risk that exposure to the chrysotile may pose (Churchill and Hill, 2000; California Air Resources Board, 2004; Van Gosen, 2005).

From a technological standpoint, asbestos was and still is the best choice for some applications; it is the only choice for a few products. Had the asbestos industry not been developed in the late 1800 s, solutions to problems that were readily solved by using asbestos would have been more complex. The reason is that many substitute materials or substitute products on the market today were not available or were not practical to use until late in the 20th century; some substitutes are discussed below:

- Wollastonite. Although wollastonite is now a substitute for asbestos in some applications, it was not even considered as a substitute for asbestos until the 1960s, and supplies were not available until large-scale wollastonite mining began in the 1950s.

- Cast-iron and plastic. Cast-iron water-supply pipe was not the best choice for use in alkaline soils, as in the southwestern United States, because it corroded and failed. Asbestos-cement pipe was the solution to that problem. Plastic pipe, another possible solution to the alkaline soil problem, was not developed until the later part of the 20th century.

- Wood. In the 1800 s, wooden structures were still commonplace, and a fire could be devastating for a city. Hence, a demand for asbestos textiles and asbestos board developed.

- Aramid fiber. One substitute for asbestos in textiles, the fire-resistant aramid fiber, was not commercialized until the 1970 s. 
The historical lack of substitutes and the technological benefits of asbestos were just a few of the reasons why the industry was established and thrived. Although a health risk was posed by excessive exposure to airborne asbestos, the use of asbestos solved many health and safety problems (reducing fire risks and improving component performance), energy conservation problems (in thermal insulations), and construction problems (as a building material that helped to further the development of society). Its use continues today in many parts of the world because of a need for inexpensive and durable (primarily asbestos-cement) products that require simple technology to make and do not require large capital investments.

Despite its continued use, the overall worldwide trend in asbestos consumption is downward because of the health issue. The largest declines have been in the United States, Western Europe, Oceania, and a few of the Asian countries, where there have been concerted efforts to ban the use of asbestos and where asbestos substitutes have become widely available and affordable. Declines have occurred in several other countries and regions because of situations including political unrest or economic instability.

For those countries that continue to use asbestos in large tonnages, other factors, such as internal needs for inexpensive construction materials, national economics, or government policy toward the use of asbestos, have overridden the asbestos health issue. The bulk of the consumption in 2003 was in Brazil, several former Soviet-bloc countries (Kazakhstan, Russia, and Ukraine), China, India, Iran, and Thailand (fig. 3, table A19). Consumption increased in most of these countries between 2000 and 2003. Except for Thailand, a major exporter of manufactured asbestos products, the increase probably resulted primarily from growing national demand for inexpensive construction materials.

In summary, world consumption declined during the 23 years between 1980 and 2003 (fig. 1). Those countries and regions experiencing the largest declines or gains in consumption over time are evident in figures 1-3 and the appendix. Where low-level asbestos-manufacturing industries remain, they appear mainly to be remnants of a past industrial capacity. In a few countries with small manufacturing industries, though, consumption has increased, possibly owing to the loss of foreign sources for some asbestos products. The industries in these countries are not likely to expand much beyond their current capacity because of the negative atmosphere regarding the use of asbestos worldwide and the greater availability of asbestos substitutes (many of whose potential long-term health risks, ironically, are unknown) and alternative materials.

\section{Conclusions}

Asbestos, despite being a carcinogen, was widely used by society. Without asbestos, the development of many products would have been delayed and, ironically, without many of the asbestos-containing products, health and safety could have been jeopardized. That asbestos is more versatile than many of its contemporary competitors cannot be denied. Following World War II, there was a large effort to synthesize asbestos and to develop asbestos substitutes because of strategic goals, not because of health concerns. Neither the synthesis nor the substitutes were immediately successful. An additional 20 years elapsed before substitutes made inroads into the asbestos market. It has taken a plethora of materials to substitute for asbestos in manufacturing.

The adverse publicity about asbestos and lawsuits have taken their toll on asbestos markets, despite much stricter asbestos regulation. Worldwide consumption declined from an estimated 4.73 Mt in 1980 to about 2.11 Mt in 2003 (tables A8 and A19). Public pressure and liability issues have forced most companies to stop manufacturing asbestos-containing products and have forced many companies into bankruptcy. Consumption has fallen off dramatically in most countries. The leading consumers of asbestos in 2003 were Brazil, China, India, Iran, Kazakhstan, Russia, Thailand, and Ukraine; each consumed more than 75,000 t. These eight countries accounted for more than 82 percent of the world's apparent consumption in 2003 (table A19). Sizable consumption increases occurred in Azerbaijan, China, India, Iran, Kazakhstan, Thailand, and Ukraine between 2000 and 2003 (tables A16 and A19).

\section{Acknowledgments}

I thank Mike Potter and Thomas Dolley, U.S. Geological Survey (USGS) mineral commodity specialists, who reviewed this Circular. I thank Linder Roberts of the USGS for compiling the data from the British Geological Survey world mineral production reports that were used in the apparent consumption estimates from 1920 to 1997 . I offer my gratitude to the following four people for helpful reviews of the USGS Open-File Report 03-083, which was expanded and updated to become this Circular: Mike Potter, USGS mineral commodity specialist; Greg Meeker, USGS geologist; Louis Perron, former asbestos specialist with Natural Resources Canada; and Bob Pigg, president of the Asbestos Information Association/North America.

\section{References Cited}

Agency for Toxic Substances and Disease Registry, 2001, Toxicological profile for asbestos: Agency for Toxic Substances and Disease Registry Web site at http://www.atsdr.cdc.gov/toxprofiles/tp61.htm. (Accessed July 27, 2005.)

Agency for Toxic Substances and Disease Registry, 2005, Asbestos exposure in Libby, Montana: Agency for Toxic Substances and Disease Registry Web site at http://www. atsdr.cdc.gov/asbestos/asbestos_study.htm. (Accessed September 27, 2005.) 
Alleman, J.E., and Mossman, B.T., 1997, Asbestos revisited: Scientific American, v. 277, no. 1, p. 70-75.

Becker \& Haag, 1928, Asbestos-Its sources, extraction, preparation, manufacture and uses in industry and engineering: Berlin, Becker \& Haag, 88 p.

Bowles, Oliver, 1934, Asbestos-Domestic and foreign deposits: U.S. Bureau of Mines Information Circular 6790, $24 \mathrm{p}$.

Bowles, Oliver, 1937, Asbestos: U.S. Bureau of Mines Bulletin 403, $92 \mathrm{p}$.

Bowles, Oliver, 1946, Asbestos-The silk of the mineral kingdom: New York, Ruberoid Co., 39 p.

Bowles, Oliver, 1955, The asbestos industry: U.S. Bureau of Mines Bulletin 552, 122 p. (Revision of USBM Bulletin 403 (Bowles, 1937).)

Bowles, Oliver, 1959, Asbestos-A materials survey: U.S. Bureau of Mines Information Circular 7880, 94 p.

Bowles, Oliver, and Barsigian, F.M., 1943, Asbestos: U.S. Bureau of Mines Minerals Yearbook 1942, p. 1423-1434. (Also available online at http://minerals.usgs.gov/minerals/ pubs/usbmmyb.html.)

Bowles, Oliver, and Barsigian, F.M., 1945, Asbestos: U.S. Bureau of Mines Minerals Yearbook 1943, p. 1473-1483. (Also available online at http://minerals.usgs.gov/minerals/ pubs/usbmmyb.html.)

Bowles, Oliver, and Cornthwaite, M.A., 1937, Asbestos: U.S. Bureau of Mines Minerals Yearbook 1937, p. 1363-1370. (Also available online at http://minerals.usgs.gov/minerals/ pubs/usbmmyb.htm.)

Bowles, Oliver, and Petron, A.C., 1943, Asbestos: U.S. Bureau of Mines Minerals Yearbook 1941, p. 1427-1438. (Also available online at http://minerals.usgs.gov/minerals/pubs/ usbmmyb.html.)

Bowles, Oliver, and Stoddard, B.H., 1930, Asbestos: U.S. Bureau of Mines Mineral Resources of the United States 1927, v. II, p. 299-311.

Bowles, Oliver, and Stoddard, B.H., 1931, Asbestos: U.S. Bureau of Mines Mineral Resources of the United States 1928, v. II, p. 97-111.

Bowles, Oliver, and Stoddard, B.H., 1933, Asbestos: U.S. Bureau of Mines Minerals Yearbook 1932-33, p. 745-752. (Also available online at http://minerals.usgs.gov/minerals pubs/usbmmyb.html.)

Bowles, Oliver, and Warner, K.G., 1940, Asbestos: U.S. Bureau of Mines Minerals Yearbook 1940, p. 1363-1372. (Also available online at http://minerals.usgs.gov/minerals/ pubs/usbmmyb.html.)
British Geological Survey, 1984, Asbestos, in World mineral statistics 1978-82; Production, exports, imports: London, Her Majesty's Stationery Office, p. 21-24.

British Geological Survey, 1991, Asbestos, in World mineral statistics 1985-89: Keyworth, Nottingham, U.K., British Geological Survey, p. 26-29.

British Geological Survey, 1995, Asbestos, in World mineral statistics 1990-94; Production, exports, imports: Keyworth, Nottingham, U.K., British Geological Survey, p. 24-27.

British Geological Survey, 2001, Asbestos, in World mineral statistics 1995-99; Production, exports, imports: Keyworth, Nottingham, U.K., British Geological Survey, p. 26-29.

British Geological Survey, 2002, Asbestos, in World mineral statistics 1996-2000: Keyworth, Nottingham, U.K., British Geological Survey, p. 25-28.

British Sulphur Corporation, 1972, Rhodesia-A special survey of the mining industry: London, British Sulphur Corporation, $95 \mathrm{p}$.

Buckingham, D.A., and Virta, R.L., 2006, Asbestos statistics; last modification April 14, 2004, in Kelly, Thomas, and Matos, Grecia, Historical statistics for mineral and material commodities in the United States: U.S. Geological Survey Data Series 140, available only online at http://minerals.usgs.gov/ds/2005/140. (Accessed May 15, 2006.)

California Air Resources Board, 2004, Naturally occurring asbestos-General information: California Air Resources Board Web site at http://www.arb.ca.gov/toxics/asbestos/ geninfo.htm. (Accessed November 9, 2004.)

Chin, Edmond, 1983, The mineral industry of China: U.S. Bureau of Mines Minerals Yearbook Centennial Edition 1981, v. III, p. 225-249. (Also available online at http://minerals.usgs.gov/minerals/pubs/usbmmyb.htm.

Chin, Edmond, 1988, The mineral industry of China: U.S. Bureau of Mines Minerals Yearbook 1986, v. III, p. 197221. (Also available online at http://minerals.usgs.gov minerals/pubs/usbmmyb.htm1.)

Chin, Edmond, and Wu, J.C., 1990, The mineral industries of China, Hong Kong, Mongolia, and Taiwan: U.S. Bureau of Mines Minerals Yearbook 1988, v. III, p. 231-286. (Also available online at http://minerals.usgs.gov/minerals/pubs/ usbmmyb.htm.)

Churchill, R.K., and Hill, R.L., comps., 2000, A general location guide for ultramafic rocks in California-Areas more likely to contain naturally occurring asbestos: California Department of Conservation, Division of Mines and Geology, Open-File Report 2000-19, 7 p., map, scale 1:1,100,000. (Also available online at http://www.arb.ca.gov/toxics/asbestos/geninfo.htm as "Map of California showing principal asbestos deposits.") 
Clarke, G.M., 1982, Zimbabwe's industrial minerals-Optimism for the future: Industrial Minerals, no. 172 (January 1982), p. 19-31.

Clifton, R.A., 1972, Asbestos: U.S. Bureau of Mines Minerals Yearbook 1970, v. I, p. 195-203. (Also available online at http://minerals.usgs.gov/minerals/pubs/usbmmyb.htm].)

Clifton, R.A., 1973, Asbestos: U.S. Bureau of Mines Minerals Yearbook 1971, v. I, p. 181-189. (Also available online at http://minerals.usgs.gov/minerals/pubs/usbmmyb.htm].)

Clifton, R.A., 1974, Asbestos: U.S. Bureau of Mines Minerals Yearbook 1972, v. I, p. 169-180. (Also available online at http://minerals.usgs.gov/minerals/pubs/usbmmyb.htm1.)

Clifton, R.A., 1975, Asbestos: U.S. Bureau of Mines Minerals Yearbook 1973, v. I, p. 171-179. (Also available online at http://minerals.usgs.gov/minerals/pubs/usbmmyb.htm. )

Clifton, R.A., 1976, Asbestos, in Mineral facts and problems, 1975 edition: U.S. Bureau of Mines Bulletin 667, p. 107-121.

Clifton, R.A., 1980a, Asbestos: U.S. Bureau of Mines Minerals Yearbook 1977, v. I, p. 145-157. (Also available online at http://minerals.usgs.gov/minerals/pubs/usbmmyb.htm1.)

Clifton, R.A., 1980b, Asbestos, in Mineral facts and problems, 1980 edition: U.S. Bureau of Mines Bulletin 671, p. 55-71.

Clifton, R.A., 1981, Asbestos: U.S. Bureau of Mines Minerals Yearbook 1980, v. I, p. 91-101. (Also available online at http://minerals.usgs.gov/minerals/pubs/usbmmyb.htm].)

Clifton, R.A., 1982, Asbestos: U.S. Bureau of Mines Minerals Yearbook Centennial Edition 1981, v. I, p. 103-112. (Also available online at http://minerals.usgs.gov/minerals/pubs/ usbmmyb.htm.)

Clifton, R.A., 1985, Asbestos, in Mineral facts and problems, 1985 edition: U.S. Bureau of Mines Bulletin 675, p. 53-64.

Cobb, H.H., 1948, The complete home handyman's guide: New York, William H. Wise and Co., Inc., 500 p.

Cossette, M., and Delvaux, P., 1979, Technical evaluation of chrysotile ore bodies, in Ledoux, R.L., ed., Short course in mineralogical techniques of asbestos determination: Mineralogical Association of Canada Short Course Handbook, v. 4, p. $79-110$.

Craynon, J.R., 1988, The mineral industry of Italy: U.S. Bureau of Mines Minerals Yearbook 1986, v. III, p. 463483. (Also available online at http://minerals.usgs.gov minerals/pubs/usbmmyb.htm].)

Diller, J.S., 1921, Asbestos: U.S. Geological Survey Mineral Resources of the United States 1918, pt. II, p. 545-556.
Evans, J.W., 1906, The identity of the amiantos or Karystian stone of the ancients with chrysotile: Mineralogical Magazine, v. 14, no. 65 (May 1906), p. 143-148.

Gössling, H.H., 1977, Asbestos-A commodity study: South Africa Department of Mines, Minerals Bureau, Internal Report No. 5, 82 p.

[Great Britain] Colonial Geological Surveys, 1956, Asbestos, in Statistical summary of the mineral industry-Production, exports and imports, 1949-1954: London, Her Majesty's Stationery Office, p. 31-37.

[Great Britain] Imperial Institute, 1932, Asbestos, in The mineral industry of the British Empire and foreign countriesStatistical summary (production, imports and exports), 1929-1931: London, His Majesty's Stationery Office, p. 34-40.

[Great Britain] Imperial Institute, 1948, Asbestos, in The mineral industry of the British Empire and foreign countriesStatistical summary (production, imports and exports), 1938-1944: London, His Majesty's Stationery Office, p. 30-36.

[Great Britain] Imperial Mineral Resources Bureau, 1924, Asbestos, in The mineral industry of the British Empire and foreign countries-Statistical summary (production, imports and exports), 1920-1922: London, His Majesty's Stationery Office, p. 23-26.

[Great Britain] Institute of Geological Sciences, 1973, Asbestos, in Statistical summary of the mineral industry-World production, exports and imports, 1967-1971: London, Her Majesty's Stationery Office, p. 34-42.

[Great Britain] Institute of Geological Sciences, 1981, Asbestos, in World mineral statistics 1975-79-Production, exports, imports: London, Her Majesty's Stationery Office, p. 19-22.

[Great Britain] Institute of Geological Sciences, Overseas Division, 1967, Asbestos, in Statistical summary of the mineral industry-World production, exports and imports, 1960-1965: London, Her Majesty's Stationery Office, p. 33-41.

Griffiths, Joyce, 1989, South Africa's minerals; Diversity in adversity: Industrial Minerals, no. 263 (August 1989), p. $18-53$.

Gross, Paul, and Braun, D.C., 1984, Toxic and biomedical effects of fibers-Asbestos, talc, inorganic fibers, manmade vitreous fibers, and organic fibers: Park Ridge, N.J., Noyes Publications, $257 \mathrm{p}$.

Harben, Peter, 1984, A profile of SA Mineração de Amianto-Brazil's asbestos producer: Industrial Minerals, no. 198 (March 1984), p. 63-65. 
Hodgson, A.A., 1989, Asbestos; Alternatives, in Carr, D.D., and Herz, Norman, eds., Concise encyclopedia of mineral resources: New York, Pergamon Press, p. 15-20.

Hoskin, W.M.A., 1991, Asbestos, in Canadian minerals yearbook 1990: Ottawa, Canada, Energy, Mines and Resources Canada, p. 10.1-10.11. (Also available online at http://www.nrcan.gc.ca/mms/cmy/archive/1990-e.pdf.)

Hoskins, J.A., 2001, Toxicological insight into low-level exposure to chrysotile, in Nolan, R.P., Langer, A.M., Ross, M., Wicks, F.J., and Martin, R.F., eds., The health effects of chrysotile asbestos: Mineralogical Association of Canada Special Publication 5, p. 251-259.

Howling, G.E., 1937, Asbestos (2d ed.): London, [Great Britain] Imperial Institute, $88 \mathrm{p}$.

Icke, P.W., 1969, Asbestos: U.S. Bureau of Mines Minerals Yearbook 1968, v. I-II, p. 179-188. (Also available online at http://minerals.usgs.gov/minerals/pubs/usbmmyb.html.)

Industrial Minerals, 1978, Greek asbestos breaks ground: Industrial Minerals, no. 129 (June 1978), p. 47, 49.

Industrial Minerals, 1980, Rhodesian mineral musings: Industrial Minerals, no. 148 (January 1980), p. 7, 15.

Industrial Minerals, 1985, Company news \& mineral notes: Industrial Minerals, no. 212 (May 1985), p. 67.

Industrial Minerals, 1993, Amosite asbestos era ends: Industrial Minerals, no. 306 (March 1993), p. 12.

Josephson, G.W., and Barsigian, F.M., 1950, Asbestos: U.S. Bureau of Mines Minerals Yearbook 1948, p. 144-155. (Also available online at http://minerals.usgs.gov/minerals pubs/usbmmyb.htm. )

Josephson, G.W., and Barsigian, F.M., 1951, Asbestos: U.S. Bureau of Mines Minerals Yearbook 1949, p. 139-148. (Also available online at http://minerals.usgs.gov/minerals pubs/usbmmyb.htm.)

Josephson, G.W., and Marsh, D.I., 1948, Asbestos: U.S. Bureau of Mines Minerals Yearbook 1946, p. 143-151. (Also available online at http://minerals.usgs.gov/minerals pubs/usbmmyb.htm. )

Kendall, Tom, 1996, Brazil-Dancing to a new tune: Industrial Minerals, no. 350 (November 1996), p. 21-51.

Kennedy, D.O., and Foley, J.M., 1960, Asbestos: U.S. Bureau of Mines Minerals Yearbook 1959, v. I, p. 199-209. (Also available online at http://minerals.usgs.gov/minerals/pubs usbmmyb.html.)

Kennedy, D.O., and Mattila, A.L., 1958, Asbestos: U.S. Bureau of Mines Minerals Yearbook 1957, v. I, p. 209-221. (Also available online at http://minerals.usgs.gov/minerals pubs/usbmmyb.htm1.)
Kupferburger, W., 1930, Mining amosite asbestos in the Pietersburg District, South Africa: Engineering and Mining Journal, v. 130, no. 11 (December 8, 1930), p. 571-574.

Loughbrough, Roger, 1992, Italy's industrial minerals; A fistful of feldspar: Industrial Minerals, no. 301 (October 1992), p. $35-57$.

Lu, Wen, 1998, Chinese industrial minerals: Worcester Park, Surrey, U.K., Industrial Minerals Information Ltd., 210 p.

Maliotis, G., and Ilich, M., 1986, The nonmetallic minerals industry of Cyprus-Its present state and future prospects, in Clarke, G.M., and Griffiths, J.B., eds., 7th Industrial Minerals International Congress, Monte Carlo, Monaco, April 1-4, 1986, Proceedings: London, Metal Bulletin, p. 1-12.

May, T.C., 1964, Asbestos: U.S. Bureau of Mines Minerals Yearbook 1963, v. I, p. 251-265. (Also available online at http://minerals.usgs.gov/minerals/pubs/usbmmyb.htm.)

May, T.C., 1965, Asbestos, in Mineral facts and problems, 1965 edition: U.S. Bureau of Mines Bulletin 630, p. 81-90.

May, T.C., and Lewis, R.W., 1970, Asbestos, in Mineral facts and problems, 1970 edition: U.S. Bureau of Mines Bulletin 650, p. 851-863.

Mining Journal, 1992, Gefco announces closure: Mining Journal, v. 318, no. 8173 (May 15, 1992), p. 354.

Mining Magazine, 1987, Balangero [mine in northern Italy]: Mining Magazine, v. 157, no. 1 (July 1987), p. 20-25.

Moore, Paul, 2004, Chrysotile in crisis: Industrial Minerals, no. 439 (April 2004), p. 56, 57, 59, 61.

Morel-à-l'Huissier, Patrick, and Hoskin, W.M.A., 1992, Asbestos, in Canadian minerals yearbook 1991: Ottawa, Canada, Energy, Mines and Resources Canada, p. 10.1-10.13. (Also available online at http://www.nrcan.gc.ca/mms/cmy archive/1991-e.pdf.)

Morrell, L.G., 1969, The mineral industry of Australia: U.S. Bureau of Mines Minerals Yearbook 1967, v. IV, p. 83-102. (Also available online at http://minerals.usgs.gov/minerals/ pubs/usbmmyb.htm.)

Munzhelele, N.N., 2000, Asbestos, in South Africa's mineral industry 1998/99: Pretoria, South Africa Department of Minerals and Energy, Mineral Economics Directorate (Minerals Bureau), p. 193-198.

Natural Resources Board of Southern Rhodesia, 1963, Asbestos: Natural Resources Board of Southern Rhodesia, Minerals of Southern Rhodesia-Minerals Year 1963, p. 14-17.

O'Driscoll, Mike, 1989, Brazil's industrial minerals; Seeking success against all odds: Industrial Minerals, no. 266 (November 1989), p. 23-69. 
Peipins, L.A., Lewin, Michael, Campolucci, Sharon, Lybarger, J.A., Miller, Aubrey, Middleton, Dan, Weis, Christopher, Spence, Michael, Black, Brad, and Kapil, Vikas, 2003, Radiographic abnormalities and exposure to asbestoscontaminated vermiculite in the community of Libby, Montana, USA: Environmental Health Perspectives, v. 111, no. 14 (November 2003), p. 1753-1759. (Also available online at http://ehp.niehs.nih.gov/members/2003/6346/ 6346.pdf.)

Perron, Louis, 2001, Chrysotile, in Canadian minerals yearbook 1999: Ottawa, Canada, Natural Resources Canada, p. 17.1-17.13. (Also available online at http://www.nrcan.gc.ca/mms/cmy/content/1999/20.pdf.)

Perron, Louis, 2003, Chrysotile, in Canadian minerals yearbook 2003: Ottawa, Canada, Natural Resources Canada, p. 18.1-18.11. (Also available online at http://www.nrcan.gc.ca/mms/cmy/content/2003/20.pdf.)

Quebec Asbestos Information Service, 1959, The strangest mineral ever known (3d ed.): Montreal, Quebec Asbestos Information Service, unpaginated.

Readling, C.L., 1971, Asbestos: U.S. Bureau of Mines Minerals Yearbook 1969, v. I-II, p. 183-191. (Also available online at http://minerals.usgs.gov/minerals/pubs/ usbmmyb.html.)

Rosato, D.V., 1959, Asbestos-Its industrial applications: New York, Reinhold Publishing Corp., 214 p.

Roskill Information Services Ltd., 1983, The economics of asbestos (4th ed.): London, Roskill Information Services Ltd., 188 p.

Roskill Information Services Ltd., 1986, The economics of asbestos (5th ed.): London, Roskill Information Services Ltd., 181 p.

Roskill Information Services Ltd., 1990, The economics of asbestos (6th ed.): London, Roskill Information Services Ltd., 190 p.

Ross, Malcolm, 1984, A survey of asbestos-related disease in trades and mining occupations and in factory and mining communities as a means of predicting health risks of nonoccupational exposure to fibrous minerals, in Levadie, Benjamin, ed., Definitions for asbestos and other health-related silicates; A symposium: American Society for Testing and Materials Special Technical Publication 834, p. 51-104.

RuKeyser, W.A., 1933a, Chrysotile asbestos in the Bajenova District, U.S.S.R.: Engineering and Mining Journal, v. 134, no. 8 (August 1933), p. 335-339.

RuKeyser, W.A., 1933b, Mining asbestos in U.S.S.R.: Engineering and Mining Journal, v. 134, no. 9 (September 1933), p. 375-381.
Sassos, M.P., 1983, Greece gears for a $100000 \mathrm{mt} / \mathrm{yr}$ rate from its first asbestos complex: Engineering and Mining Journal, v. 184, no. 4 (April 1983), p. 66-67.

Selikoff, I.J., and Lee, D.H.K., 1978, Asbestos and disease: New York, Academic Press, 549 p.

Sinclair, W.E., 1959, Asbestos-Its origin, production, and utilization ( $2 \mathrm{~d}$ ed.): London, Mining Publications, $512 \mathrm{p}$.

Skillen, Andy, 1993, Greek minerals outlook; Privatisation a key issue: Industrial Minerals, no. 313 (October 1993), p. $31-49$.

Sokoloff, V.P., 1964, The mineral industry of the U.S.S.R.: U.S. Bureau of Mines Minerals Yearbook 1963, v. IV, p. 749-778. (Also available online at http://minerals.usgs.gov/minerals pubs/usbmmyb.htm,.)

Sondermayer, R.V., 1987, The mineral industry of Italy: U.S. Bureau of Mines Minerals Yearbook 1985, v. III, p. 473-490. (Also available online at http://minerals.usgs.gov/minerals, pubs/usbmmyb.htm.)

South African Mining Journal, 1949, Mining in N. Transvaal: South African Mining Journal, v. 60, no. 2956 (October 8, 1949), p. 153.

Stover Publishing Co., 1953, The asbestos fact book (3d ed.): Willow Grove, Pa., Stover Publishing Co., 19 p.

Strishkov, V.V., 1973, The mineral industry of the U.S.S.R.: U.S. Bureau of Mines Minerals Yearbook 1971, v. III, p. 821-871. (Also available online at http://minerals.usgs.gov/minerals pubs/usbmmyb.htm.)

Strishkov, V.V., 1980, The mineral industry of the U.S.S.R.: U.S. Bureau of Mines Minerals Yearbook 1976, v. III, p. 1065-1134. (Also available online at http://minerals.usgs.gov/minerals/pubs/usbmmyb.htm.)

Strishkov, V.V., 1981a, The mineral industry of the U.S.S.R: U.S. Bureau of Mines Minerals Yearbook 1977, v. III, p. 959-1026. (Also available online at http://minerals.usgs.gov/minerals/pubs/usbmmyb.htm.)

Strishkov, V.V., 1981b, The mineral industry of the U.S.S.R: U.S. Bureau of Mines Minerals Yearbook 1978-1979, v. III, p. 957-1005. (Also available online at http://minerals.usgs.gov/minerals/pubs/usbmmyb.htm.)

Summers, A.L., [1919], Asbestos and the asbestos industryThe world's most wonderful mineral and other fireproof materials: New York, Sir Isaac Pitman \& Sons, Ltd., 107 p.

Sutulov, Alexander, 1973, Mineral resources and the economy of the USSR: New York, Engineering and Mining Journal, $192 \mathrm{p}$.

Tverskoi, Igor, 1968, Asbestos in the U.S.S.R.: Mining in Canada, v. 41, no. 6 (June 1968), p. 31-32. 
United Nations Statistics Division, 2005, United Nations commodity trade statistics database (UN Comtrade): United Nations Statistics Division Web site at http://unstats.un.org unsd/comtrade. (Accessed June 8, 2005.)

U.S. Bureau of Mines, 1927-1933, Asbestos: U.S. Bureau of Mines Mineral Resources of the United States 1924-1931, variously paginated. (Asbestos chapter authors: B.H. Stoddard, in volumes for 1924-1926; Oliver Bowles and B.H. Stoddard, 1927-1931.)

U.S. Bureau of Mines, 1933-1996, Asbestos: U.S. Bureau of Mines Minerals Yearbook 1932-33 to 1994, variously paginated. (Also available online at http://minerals.usgs.gov minerals/pubs/usbmmyb.htm.) (Some of these chapters are also cited by personal authors; see Bowles and Stoddard, 1933; Bowles and Cornthwaite, 1937; Bowles and Warner, 1940; Bowles and Barsigian, 1943, 1945; Bowles and Petron, 1943; Josephson and Marsh, 1948; Josephson and Barsigian, 1950, 1951; Kennedy and Mattila, 1958; Kennedy and Foley, 1960; May, 1964; Icke, 1969; Readling, 1971; Clifton, 1972, 1973, 1974, 1975, 1980a, 1981, 1982; Virta, 1987.)

U.S. Department of Health and Human Services, National Institute for Occupational Safety and Health (NIOSH), 1992, Asbestos publications: Cincinnati, U.S. Department of Health and Human Services, NIOSH, 190 p.

U.S. Geological Survey, 1901-1926, Asbestos: U.S. Geological Survey Mineral Resources of the United States 19001923, pt. II, variously paginated. (Asbestos chapter authors: J.H. Pratt, in volumes for 1900-1904; G.O. Smith, 1905; J.S. Diller, 1906-1919; Edward Sampson, 1920-1923.)

U.S. Geological Survey, 1997-2005, Asbestos: U.S. Geological Survey Minerals Yearbook 1995-2003, variously paginated. (Also available online at http://minerals.usgs.gov/minerals, pubs/commodity/asbestos,.) (These asbestos chapters were by R.L. Virta; some are also cited by the personal author.)

U.S. International Trade Commission, 2006, Interactive Tariff and Trade Dataweb: U.S. International Trade Commission Web site at http://dataweb.usitc.gov, (Accessed May 22, 2006.)

Vagt, G.O., 1975, Asbestos, in Canadian minerals yearbook 1973: Ottawa, Canada, Energy, Mines and Resources Canada, p. 41-49. (Also available online at http://www.nrcan.gc.ca mms/cmy/archive/1973-e.pdf.)

van der Merwe, C.J., 1989, Asbestos, in South Africa's mineral industry 1988: Braamfontein, South Africa Department of Mineral and Energy Affairs, Minerals Bureau, p. 141-145.

Van Gosen, B.S., 2005, Reported historic asbestos mines, historic asbestos prospects, and natural asbestos occurrences in the eastern United States: U.S. Geological Survey Open-File Report 2005-1189, database and map [scale about 1:2,000,000], available only online at http://pubs.usgs.gov of/2005/1189. (Accessed September 27, 2005.)
Vance, A.G., 1975, Asbestos industry suffers through troubled year: The Northern Miner, v. 61, no. 37 (November 27, 1975), p. B12, B13, B26.

Virta, R.L., 1987, Asbestos: U.S. Bureau of Mines Minerals Yearbook 1985, v. I, p. 143-149. (Also available online at http://minerals.usgs.gov/minerals/pubs/usbmmyb.htm.)

Virta, R.L., 1994, Asbestos substitutes, in Carr, D.D., ed., Industrial minerals and rocks (6th ed.): Littleton, Colo., Society for Mining, Metallurgy, and Exploration, Inc., p. 429-434.

Virta, R.L., 2001, Some facts about asbestos: U.S. Geological Survey Fact Sheet FS-012-01, 4 p. (Also available online at http://pubs.usgs.gov/fs/fs012-01.)

Virta, R.L., 2002, Asbestos-Geology, mineralogy, mining, and uses: U.S. Geological Survey Open-File Report 02-149, 35 p., available only online at http://pubs.usgs.gov/of/2002 of02-149,.)

Virta, R.L, 2003a, Asbestos: U.S. Geological Survey Minerals Yearbook 2001, v. I, p. 8.1-8.6. (Also available online at http://minerals.usgs.gov/minerals/pubs/commodity/asbestos/index.html.)

Virta, R.L., 2003b, Worldwide asbestos supply and consumption trends from 1900 to 2000: U.S. Geological Survey Open-File Report 03-083, 59 p. (Also available online at http://pubs.usgs.gov/of/2003/of03-083.)

Virta, R.L, 2005a, Asbestos: U.S. Geological Survey Minerals Yearbook 2004, v. I, p. 8.1-8.11, available only online at http://minerals.usgs.gov/minerals/pubs/commodity/asbestos/ index.htm. (Accessed October 15, 2005.)

Virta, R.L., 2005b, Mineral commodity profiles-Asbestos: U.S. Geological Survey Circular 1255-KK, 56 p., available only online at http://pubs.usgs.gov/circ/2005/1255/kk.

Wang, K.P., 1967, The mineral industry of mainland China: U.S. Bureau of Mines Minerals Yearbook 1965, v. IV, p. 1107-1120. (Also available online at http://minerals.usgs.gov/minerals/pubs/usbmmyb.htm.)

Wang, K.P., 1978, The mineral industry of the People's Republic of China: U.S. Bureau of Mines Minerals Yearbook 1975, v. III, p. 285-304. (Also available online at http://minerals.usgs.gov/minerals/pubs/usbmmyb.htm. )

Wang, K.P., 1981, The mineral industry of China: U.S. Bureau of Mines Minerals Yearbook 1978-79, v. III, p. 233-269. (Also available online at http://minerals.usgs.gov/minerals pubs/usbmmyb.htm.) 


\section{Figures 1-3 and tables 1-4}

[The appendix follows table 4] 


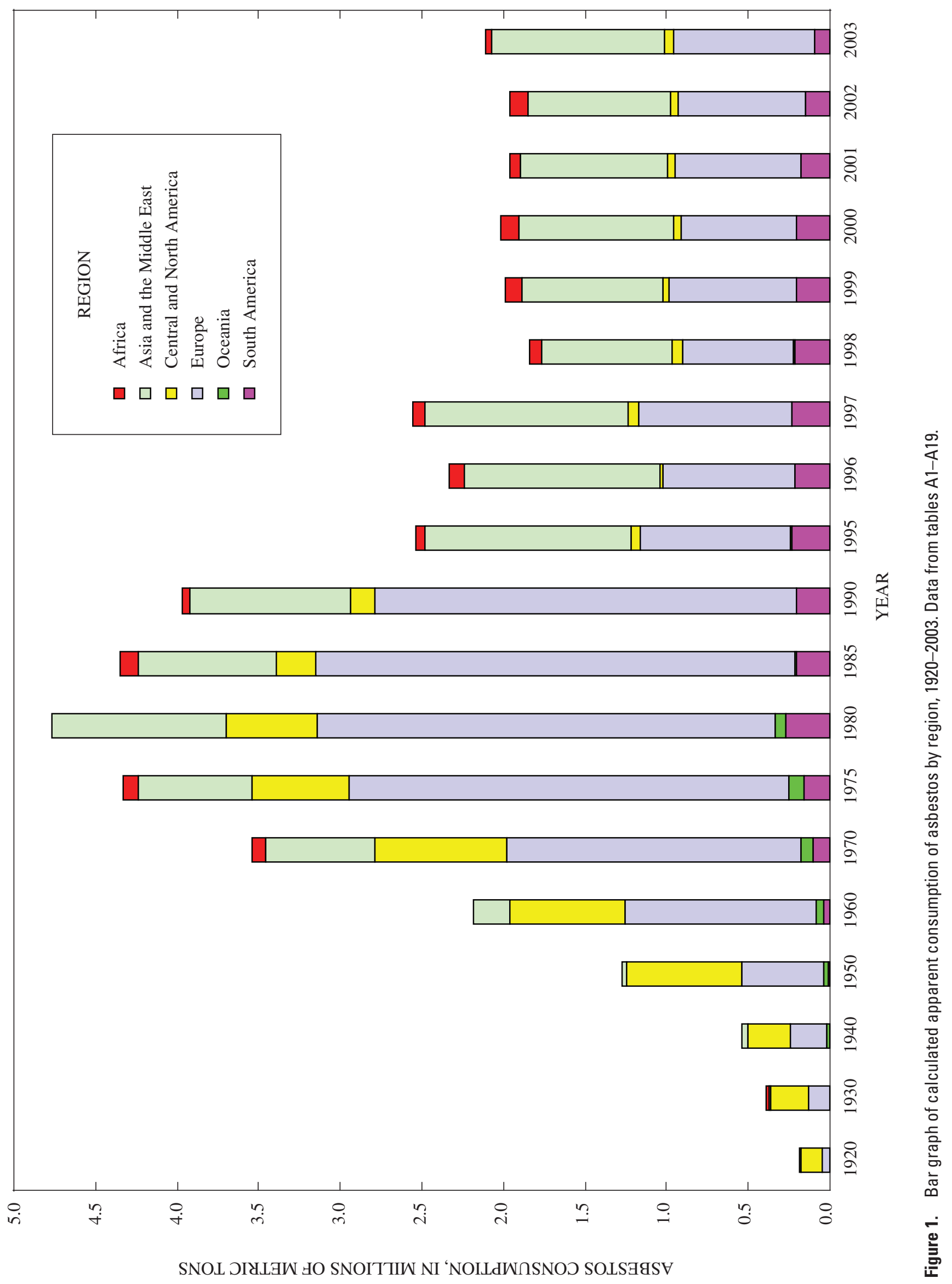




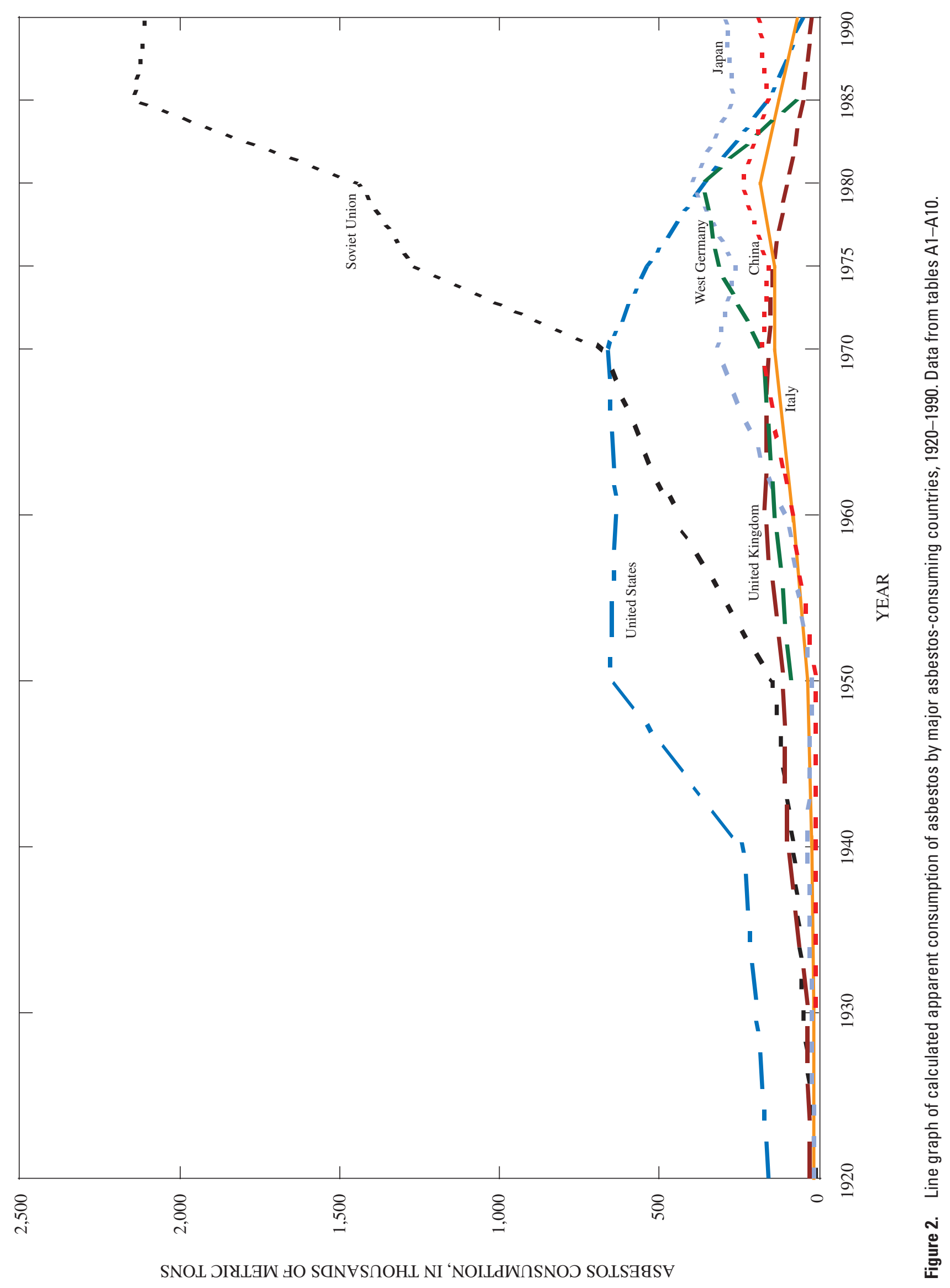




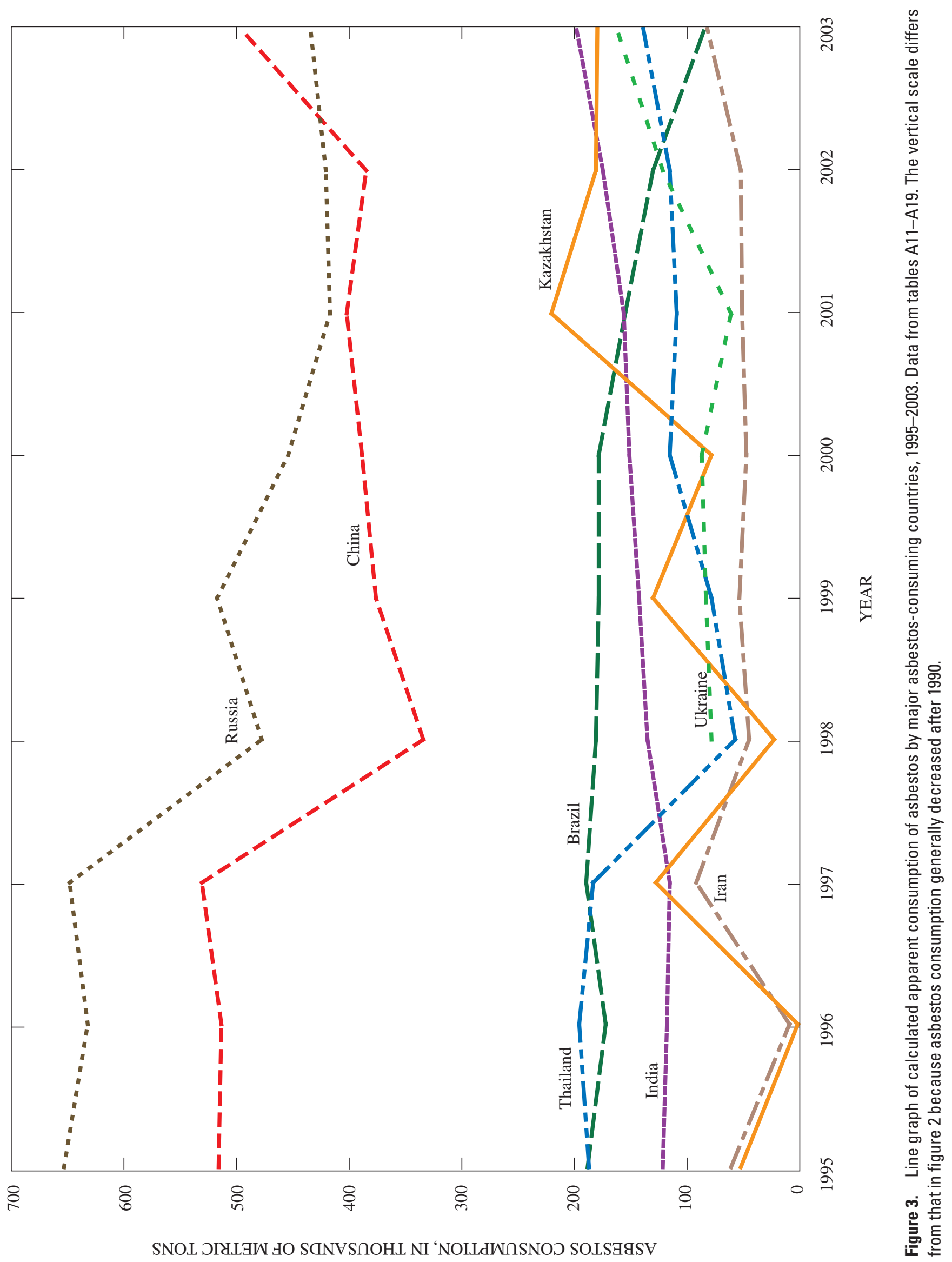


Table 1. Early developments of the asbestos industry.

[Information from Stover Publishing Co., 1953, p. 4-6; Selikoff and Lee, 1978, p. 17-18]

\begin{tabular}{|c|c|}
\hline 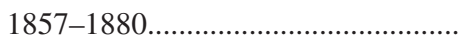 & First packings and flat seals using asbestos. \\
\hline 1866. & First bonded and molded asbestos product for heat insulation. \\
\hline $1866-1876 \ldots$ & Start of systematic asbestos textile processing in Italy. \\
\hline $1868-1869 .$. & First U.S. use of asbestos in roofing felt and cement. \\
\hline $1878 \ldots$ & Asbestos paper first made in the United States. \\
\hline $1882 .$. & Concept of asbestos-containing magnesia insulation developed. \\
\hline $1890 \ldots$ & Asbestos textile processing began in Canada. \\
\hline $1893 .$. & First spinning of crocidolite in Republic of South Africa. \\
\hline $1896 \ldots$ & First asbestos-containing woven brake bands made in England. \\
\hline 1899. & Wet machine process of making asbestos cement developed. \\
\hline $1900 \ldots . .$. & Method for manufacturing asbestos-cement panels developed. \\
\hline $1904 \ldots$ & Flat asbestos-cement board manufactured in the United States. \\
\hline $1906 .$. & Asbestos first used as brake lining. \\
\hline $1918 \ldots$ & Asbestos-containing molded clutch facing developed. \\
\hline $1929 \ldots$ & Asbestos-cement pipe industry began in the United States. \\
\hline $1931 \ldots \ldots \ldots \ldots . . . .$. & Technique for spraying asbestos developed in England. \\
\hline $1940 \mathrm{~s} \ldots \ldots$. & Asbestos-cement pipe introduced into England. \\
\hline $1944 \ldots$ & Spraying asbestos on deckheads and bulkheads began in British naval ships. \\
\hline
\end{tabular}


Table 2. Salient U.S. statistics for asbestos, 1900 through 2003.

[Data in metric tons. Terms used: eestimated; NA, not available; W, withheld to avoid revealing company proprietary data; -, zero. Data from U.S. Geological Survey, 1901-1926, 1997-2005; U.S. Bureau of Mines, 1927-1933, 1933-1996]

\begin{tabular}{|c|c|c|c|c|c|c|c|c|}
\hline Year & $\begin{array}{c}\text { Domestic sales } \\
\text { or use }^{1}\end{array}$ & $\begin{array}{l}\text { Total asbestos } \\
\text { imports }\end{array}$ & $\begin{array}{l}\text { Imports from } \\
\text { Canada }\end{array}$ & $\begin{array}{l}\text { Imports from } \\
\text { South Africa }\end{array}$ & $\begin{array}{l}\text { Crocidolite } \\
\text { imports }\end{array}$ & $\begin{array}{l}\text { Amosite } \\
\text { imports }\end{array}$ & $\begin{array}{c}\text { Asbestos } \\
\text { exports }\end{array}$ & $\begin{array}{c}\text { Apparent } \\
\text { consumption }\end{array}$ \\
\hline $1900 \ldots \ldots . . . .$. & 956 & ${ }^{\mathrm{e}} 19,500$ & NA & NA & NA & NA & NA & e 20,400 \\
\hline $1901 \ldots \ldots . . .$. & 678 & e 33,500 & NA & NA & NA & NA & NA & $\mathrm{e} 34,200$ \\
\hline $1902 \ldots \ldots \ldots$ & 912 & e 41,100 & NA & NA & NA & NA & NA & e 42,000 \\
\hline $1903 \ldots \ldots \ldots$ & 805 & e 31,500 & NA & NA & NA & NA & NA & $\mathrm{e} 32,400$ \\
\hline $1904 \ldots \ldots . .$. & 1,343 & e 36,500 & NA & NA & NA & NA & NA & e 37,900 \\
\hline $1905 \ldots \ldots \ldots$ & 2,820 & e 51,000 & NA & NA & NA & NA & NA & e 53,800 \\
\hline $1906 \ldots \ldots \ldots$ & 1,538 & e 54,000 & NA & NA & NA & NA & NA & e 55,900 \\
\hline $1907 \ldots \ldots \ldots$. & 592 & e 55,000 & NA & NA & NA & NA & NA & e 55,600 \\
\hline $1908 \ldots \ldots . . .$. & 849 & e 46,200 & NA & NA & NA & NA & NA & e 47,100 \\
\hline $1909 \ldots \ldots . .$. & 2,799 & ${ }^{\mathrm{e}} 44,400$ & NA & NA & NA & NA & NA & ${ }^{\mathrm{e}} 47,200$ \\
\hline $1910 \ldots \ldots . .$. & 3,350 & 48,270 & 48,079 & NA & NA & NA & NA & 46,400 \\
\hline $1911 \ldots \ldots \ldots$ & 6,898 & 58,038 & 57,861 & NA & NA & NA & NA & 58,700 \\
\hline $1912 \ldots \ldots \ldots$ & 3,994 & 64,900 & 64,797 & NA & NA & NA & NA & 68,900 \\
\hline $1913 \ldots \ldots . .$. & 905 & 88,100 & 87,953 & NA & NA & NA & NA & 89,100 \\
\hline $1914 \ldots \ldots \ldots$ & 1,026 & 65,200 & 65,119 & NA & NA & NA & NA & 66,300 \\
\hline $1915 \ldots \ldots \ldots$ & 1,424 & 84,900 & 84,881 & NA & NA & NA & NA & 86,500 \\
\hline $1916 \ldots \ldots . .$. & 1,217 & 105,000 & 104,306 & 102 & NA & NA & NA & 107,000 \\
\hline $1917 \ldots \ldots \ldots$ & 1,385 & 122,000 & 119,318 & 1,624 & NA & NA & NA & 123,000 \\
\hline $1918 \ldots \ldots . .$. & 825 & 125,000 & 122,300 & 759 & $\mathrm{NA}$ & $\mathrm{NA}$ & NA & 125,000 \\
\hline $1919 \ldots \ldots \ldots$ & 955 & 123,000 & 121,256 & 816 & NA & NA & NA & 123,000 \\
\hline $1920 \ldots \ldots \ldots$ & 1,356 & 152,000 & 147,615 & 2,025 & NA & NA & NA & 153,000 \\
\hline $1921 \ldots \ldots \ldots$ & 754 & 65,700 & 64,784 & 457 & NA & NA & NA & 66,000 \\
\hline $1922 \ldots \ldots \ldots$ & 61 & 136,000 & 133,897 & 373 & NA & NA & NA & 135,000 \\
\hline $1923 \ldots \ldots . .$. & 206 & 193,000 & 188,929 & 254 & NA & NA & NA & 192,000 \\
\hline $1924 \ldots \ldots . .$. & 272 & 166,000 & 163,340 & 943 & NA & NA & NA & 165,000 \\
\hline $1925 \ldots \ldots \ldots$ & 1,141 & 209,000 & 204,968 & 382 & NA & NA & NA & 209,000 \\
\hline $1926 \ldots \ldots . .$. & 1,232 & 234,000 & 229,054 & 2,182 & NA & NA & NA & 234,000 \\
\hline $1927 \ldots \ldots \ldots$ & 2,704 & 203,000 & 195,753 & 3,156 & NA & NA & NA & 205,000 \\
\hline $1928 \ldots \ldots \ldots$ & 2,031 & 209,000 & 200,796 & 2,920 & NA & NA & NA & 210,000 \\
\hline $1929 \ldots \ldots . .$. & 2,862 & 238,000 & 228,672 & 3,338 & NA & NA & NA & 240,000 \\
\hline $1930 \ldots \ldots \ldots$ & 3,848 & 189,000 & 181,499 & 1,730 & NA & NA & NA & 192,000 \\
\hline $1931 \ldots \ldots . .$. & 2,928 & 123,705 & 118,031 & 747 & NA & NA & 1,555 & 125,000 \\
\hline $1932 \ldots \ldots . .$. & 3,229 & 87,774 & 85,883 & 192 & NA & NA & 1,549 & 89,500 \\
\hline $1933 \ldots \ldots \ldots$ & 4,305 & 108,447 & 102,435 & 211 & NA & NA & 1,250 & 112,000 \\
\hline $1934 \ldots \ldots . .$. & 4,615 & 109,165 & 102,566 & 540 & NA & $\mathrm{NA}$ & 1,514 & 112,000 \\
\hline $1935 \ldots \ldots \ldots$ & 8,092 & 151,124 & 139,921 & 857 & NA & NA & 771 & 158,000 \\
\hline $1936 \ldots \ldots \ldots$ & 10,037 & 220,992 & 205,095 & 1,887 & NA & NA & 3,397 & 228,000 \\
\hline $1937 \ldots \ldots . .$. & 10,958 & 278,677 & 250,392 & 3,854 & NA & NA & 2,725 & 287,000 \\
\hline $1938 \ldots \ldots . .$. & 9,471 & 162,831 & 150,657 & 3,336 & NA & NA & 2,522 & 170,000 \\
\hline $1939 \ldots \ldots . .$. & 14,024 & 220,048 & 203,064 & 5,769 & NA & NA & 2,243 & 232,000 \\
\hline
\end{tabular}


Table 2. Salient U.S. statistics for asbestos, 1900 through 2003.—Continued

[Data in metric tons. Terms used: eestimated; NA, not available; W, withheld to avoid revealing company proprietary data; -, zero. Data from U.S. Geological Survey, 1901-1926, 1997-2005; U.S. Bureau of Mines, 1927-1933, 1933-1996]

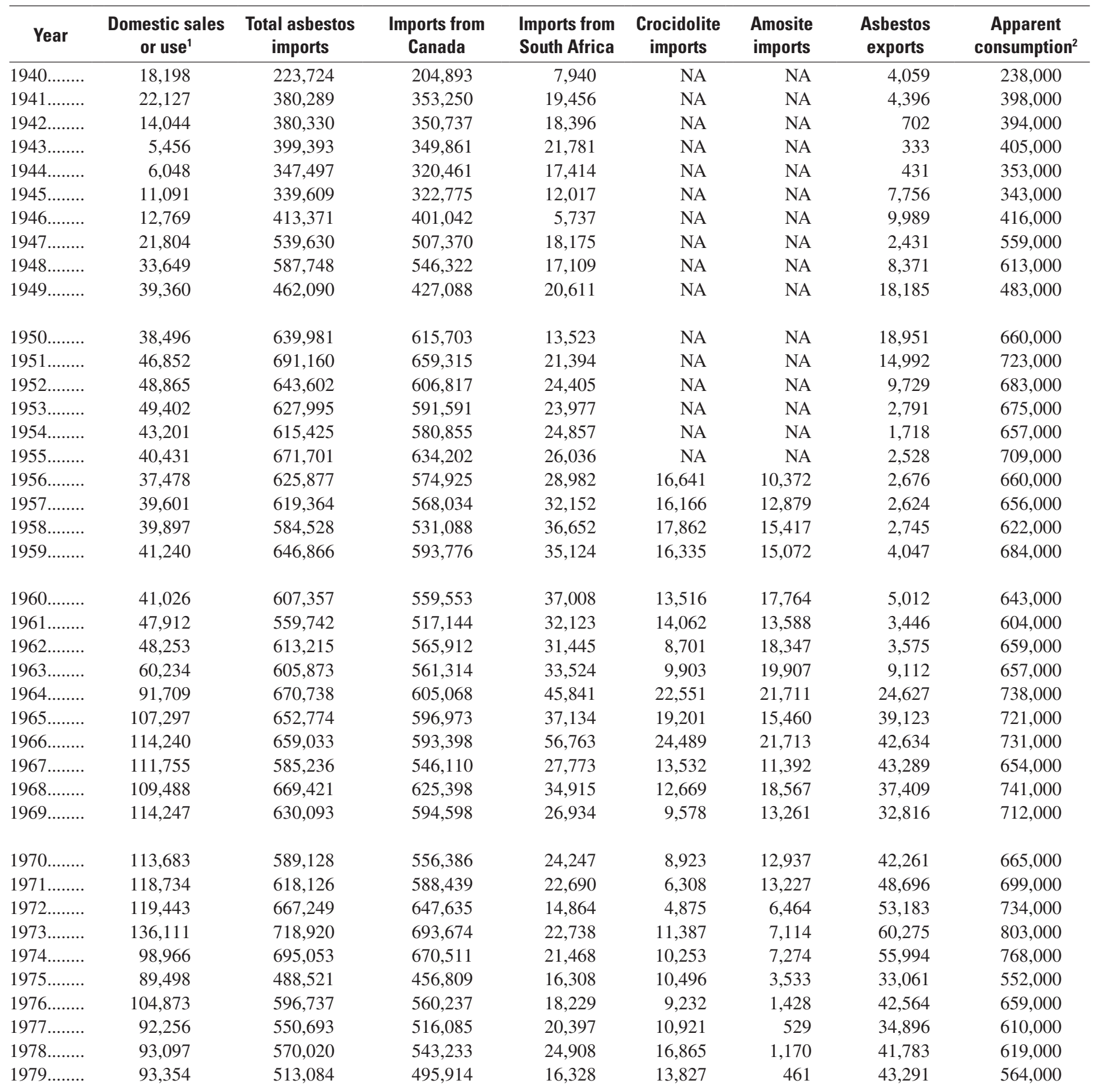


Table 2. Salient U.S. statistics for asbestos, 1900 through 2003.-Continued

[Data in metric tons. Terms used: eestimated; NA, not available; W, withheld to avoid revealing company proprietary data; -, zero. Data from U.S. Geological Survey, 1901-1926, 1997-2005; U.S. Bureau of Mines, 1927-1933, 1933-1996]

\begin{tabular}{|c|c|c|c|c|c|c|c|c|}
\hline Year & $\begin{array}{l}\text { Domestic sales } \\
\text { or use }^{1}\end{array}$ & $\begin{array}{l}\text { Total asbestos } \\
\text { imports }\end{array}$ & $\begin{array}{l}\text { Imports from } \\
\text { Canada }\end{array}$ & $\begin{array}{l}\text { Imports from } \\
\text { South Africa }\end{array}$ & $\begin{array}{l}\text { Crocidolite } \\
\text { imports }\end{array}$ & $\begin{array}{l}\text { Amosite } \\
\text { imports }\end{array}$ & $\begin{array}{l}\text { Asbestos } \\
\text { exports }\end{array}$ & $\begin{array}{c}\text { Apparent } \\
\text { consumption }^{2}\end{array}$ \\
\hline $1980 \ldots \ldots . .$. & 80,079 & 327,296 & 315,540 & 10,261 & 7,597 & 364 & 48,671 & 356,000 \\
\hline $1982 \ldots \ldots .$. & 63,515 & 241,737 & 229,079 & 11,390 & 7,904 & 389 & 58,771 & 247,000 \\
\hline $1983 \ldots \ldots . .$. & 69,906 & 196,387 & 184,303 & 11,754 & 6,177 & 609 & 54,634 & 217,000 \\
\hline $1984 \ldots \ldots . .$. & 57,422 & 209,963 & 195,651 & 13,912 & 5,656 & 715 & 39,919 & 226,000 \\
\hline $1986 \ldots \ldots . .$. & 51,437 & 108,352 & 103,517 & 4,455 & 1,988 & - & 47,281 & 120,000 \\
\hline $1987 \ldots \ldots . .$. & 50,600 & 93,763 & 90,224 & 3,246 & 1,113 & - & 60,084 & 84,000 \\
\hline $1988 \ldots \ldots . .$. & 18,233 & 85,326 & 79,690 & 4,288 & 1,252 & - & 31,544 & 71,000 \\
\hline $1989 \ldots \ldots .$. & 17,427 & 55,306 & 53,572 & 1,040 & 593 & - & 27,004 & 55,000 \\
\hline $1990 \ldots \ldots . .$. & W & 41,348 & 40,380 & 835 & 835 & - & 27,965 & 41,000 \\
\hline $1994 \ldots \ldots . .$. & 10,100 & 25,800 & 25,700 & - & - & - & 17,500 & 27,000 \\
\hline $1995 \ldots \ldots .$. & 9,000 & 21,900 & 21,800 & - & 192 & - & 14,600 & 22,000 \\
\hline $1996 \ldots \ldots . .$. & 9,550 & 21,600 & 21,400 & 15 & ${ }^{3} 197$ & - & 15,400 & 21,700 \\
\hline $1997 \ldots \ldots . .$. & 6,890 & 20,900 & 20,700 & 14 & ${ }^{3} 238$ & - & 20,300 & 21,000 \\
\hline $1998 \ldots \ldots . .$. & 5,760 & 15,800 & 15,700 & 10 & ${ }^{3} 228$ & - & 18,100 & 15,800 \\
\hline $1999 \ldots \ldots . .$. & 7,190 & 15,800 & 14,300 & 293 & $3-$ & - & 21,700 & 15,800 \\
\hline $2000 \ldots \ldots .$. & 5,260 & 14,600 & 14,500 & 53 & ${ }^{3} 67$ & - & 18,800 & 14,600 \\
\hline $2001 \ldots \ldots . .$. & 5,260 & 13,100 & 12,700 & 183 & ${ }^{3}-$ & - & 21,700 & 13,100 \\
\hline $2002 \ldots \ldots .$. & 2,720 & 6,850 & 6,630 & 176 & ${ }^{3}-$ & - & 6,550 & 6,850 \\
\hline $2003 \ldots \ldots .$. & - & 4,650 & 4,510 & 55 & ${ }^{3}-$ & - & 2,820 & 4,650 \\
\hline
\end{tabular}

${ }^{1}$ Domestic sales or use is equivalent to U.S. production.

${ }^{2}$ Apparent consumption for this Circular is defined as production plus imports minus exports; in this table, most apparent consumption values for 1910-2002 are from Buckingham and Virta (2006), who included changes to government and industry stocks when available. Apparent consumption is also called "demand" in the text. After 1988, apparent consumption was assumed to be approximately equal to total asbestos imports.

${ }^{3}$ Number reported by the U.S. International Trade Commission (2006). Crocidolite imports for 1995, 1996, 1997, 1998, and 2000 are estimated to have been less than 5 t. Most of the asbestos imports reported as crocidolite after 1995 are believed to have been chrysotile on the basis of their sources and customs values. 
Table 3. U.S. end uses for asbestos, 1965 through 2003.

[Data in thousands of metric tons. Terms used: estimated; - zero. All data for 1965-1971 are estimated, as indicated by the letter following the year (1965 ). Data from U.S. Bureau of Mines, 1933-1996; May, 1965; May and Lewis, 1970; Clifton, 1976, 1980b, p. 63, 1985; U.S. Geological Survey, 1997-2005]

\begin{tabular}{|c|c|c|c|c|c|c|c|c|c|c|c|c|c|c|c|}
\hline \multirow[t]{2}{*}{ Year } & \multicolumn{2}{|c|}{$\begin{array}{c}\text { Asbestos } \\
\text { cement }\end{array}$} & \multirow{2}{*}{$\begin{array}{l}\text { Coatings } \\
\text { and com- } \\
\text { pounds }\end{array}$} & \multirow{2}{*}{ Flooring } & \multirow{2}{*}{$\begin{array}{l}\text { Friction } \\
\text { products }\end{array}$} & \multicolumn{2}{|c|}{ Insulation } & \multirow{2}{*}{$\begin{array}{l}\text { Pack- } \\
\text { ing and } \\
\text { gaskets }\end{array}$} & \multirow[t]{2}{*}{ Paper } & \multirow[t]{2}{*}{ Plastics } & \multirow[t]{2}{*}{ Roofing } & \multirow{2}{*}{$\begin{array}{l}\text { Tex- } \\
\text { tiles }\end{array}$} & \multirow[t]{2}{*}{ Other ${ }^{1}$} & \multirow{2}{*}{$\begin{array}{c}\text { Un- } \\
\text { known' }\end{array}$} & \multirow[t]{2}{*}{ Total $\left.\right|^{3,4}$} \\
\hline & Pipe & Sheet & & & & Electrical & Thermal & & & & & & & & \\
\hline$\overline{1965^{\mathrm{e}} \ldots \ldots . . .}$ & 137 & 50 & $(5)$ & 181 & 64 & 22 & $\left({ }^{6}\right)$ & 22 & 15 & $(5)$ & 72 & 15 & 144 & - & $\overline{721}$ \\
\hline $1966^{\mathrm{e}} \ldots \ldots$. & 139 & 51 & $\left({ }^{5}\right)$ & 183 & 65 & 22 & $\left({ }^{6}\right)$ & 22 & 14 & $\left({ }^{5}\right)$ & 73 & 15 & 147 & - & 730 \\
\hline $1967^{\mathrm{e}} \ldots \ldots .$. & 122 & 46 & $\left({ }^{5}\right)$ & 162 & 59 & 20 & $\left({ }^{6}\right)$ & 20 & 13 & $\left({ }^{5}\right)$ & 64 & 13 & 132 & - & 650 \\
\hline $1968^{\mathrm{e}} \ldots \ldots .$. & 141 & 52 & $(5)$ & 185 & 67 & 23 & $\left({ }^{6}\right)$ & 23 & 15 & $(5)$ & 74 & 15 & 148 & - & 741 \\
\hline $1971^{\mathrm{e}} \ldots \ldots$ & 131 & 48 & $\left({ }^{5}\right)$ & 173 & 62 & 21 & $\left({ }^{6}\right)$ & 21 & 14 & $\left({ }^{5}\right)$ & 69 & 13 & 137 & - & 689 \\
\hline $1972 \ldots \ldots$. & 140 & 52 & $\left({ }^{5}\right)$ & 183 & 66 & 22 & $\left({ }^{6}\right)$ & 22 & 15 & $(5)$ & 73 & 14 & 147 & - & 733 \\
\hline $1973 \ldots \ldots \ldots$ & 151 & 58 & $\left({ }^{5}\right)$ & 198 & 72 & 23 & $\left({ }^{6}\right)$ & 24 & 16 & $\left({ }^{5}\right)$ & 79 & 16 & 158 & - & 795 \\
\hline $1974 \ldots \ldots . .$. & 202 & 86 & $(5)$ & 139 & 73 & 13 & $\left({ }^{6}\right)$ & 26 & 57 & $\left({ }^{5}\right)$ & 69 & 18 & 85 & - & 768 \\
\hline $1979 \ldots \ldots . .$. & 96 & 22 & 30 & 125 & 48 & 14 & 3 & 23 & 6 & 7 & 58 & 8 & 121 & - & 561 \\
\hline $1980 \ldots \ldots . . .$. & 42 & 23 & 11 & 70 & 52 & 6 & 3 & 12 & 1 & 2 & 24 & 2 & 111 & - & 359 \\
\hline $1981 \ldots \ldots \ldots$ & 42 & 20 & 13 & 67 & 51 & 6 & 1 & 19 & 2 & 1 & 16 & 2 & 109 & - & 349 \\
\hline $1982 \ldots \ldots \ldots$ & 38 & 11 & 25 & 49 & 53 & - & 1 & 14 & 2 & - & 7 & 1 & 46 & - & 247 \\
\hline $1983 \ldots \ldots \ldots$ & 26 & 10 & 23 & 45 & 48 & - & 1 & 12 & 2 & 1 & 6 & 1 & 42 & - & 217 \\
\hline $1984 \ldots \ldots . .$. & 37 & 12 & 22 & 46 & 48 & $\left({ }^{7}\right)$ & 2 & 13 & 2 & 1 & 7 & 2 & 33 & - & 226 \\
\hline $1985 \ldots \ldots . .$. & 28 & 7 & 23 & 7 & 34 & $\left({ }^{7}\right)$ & $\left({ }^{7}\right)$ & 6 & 17 & $\left({ }^{7}\right)$ & 26 & 1 & 5 & 7 & 162 \\
\hline $1986 \ldots \ldots . . .$. & 20 & 5 & 17 & 5 & 26 & $\left({ }^{7}\right)$ & $\left({ }^{7}\right)$ & 5 & 13 & $\left({ }^{7}\right)$ & 20 & $\left({ }^{7}\right)$ & 4 & 4 & 120 \\
\hline $1987 \ldots \ldots \ldots$ & 11 & 4 & 3 & - & 21 & $\left({ }^{7}\right)$ & - & 10 & 5 & 1 & 23 & 1 & 2 & 4 & 84 \\
\hline $1988 \ldots \ldots \ldots$ & 12 & 4 & 4 & $\left({ }^{7}\right)$ & 15 & $\left({ }^{7}\right)$ & $\left({ }^{7}\right)$ & 10 & 1 & $\left({ }^{7}\right)$ & 20 & $\left({ }^{7}\right)$ & $\left({ }^{7}\right)$ & 5 & 71 \\
\hline $1995 \ldots \ldots . .$. & - & - & $\left({ }^{7}\right)$ & - & 7 & - & - & 3 & $\left({ }^{7}\right)$ & $\left({ }^{7}\right)$ & 11 & - & 1 & $\left({ }^{7}\right)$ & 22 \\
\hline $1996 \ldots \ldots . . .$. & - & - & $\left({ }^{7}\right)$ & - & 7 & - & - & 3 & $\left({ }^{7}\right)$ & $\left({ }^{7}\right)$ & 11 & - & 1 & $\left({ }^{7}\right)$ & 22 \\
\hline $1997 \ldots \ldots . .$. & - & - & $\left(7^{7}\right)$ & - & 6 & - & - & 4 & $\left({ }^{7}\right)$ & $\left(7^{7}\right)$ & 10 & - & 1 & $\left({ }^{7}\right)$ & 21 \\
\hline $1998 \ldots \ldots . . .$. & - & - & $\left(7^{7}\right)$ & - & 3 & - & - & 2 & 1 & $\left({ }^{7}\right)$ & 9 & - & 1 & - & 16 \\
\hline $1999 \ldots \ldots . . .$. & - & - & $\left(7^{7}\right)$ & - & 2 & - & - & 3 & - & $\left(7^{7}\right)$ & 10 & - & 1 & - & 16 \\
\hline $2000 \ldots \ldots \ldots$ & - & - & $\left(7^{7}\right)$ & - & 2 & - & $\left({ }^{7}\right)$ & 3 & - & $\left(7^{7}\right)$ & 9 & - & 1 & - & 15 \\
\hline $2001 \ldots \ldots . .$. & - & - & $\left({ }^{7}\right)$ & - & 1 & - & - & 2 & - & $\left({ }^{7}\right)$ & 9 & - & 1 & - & 13 \\
\hline $2002 \ldots \ldots \ldots$ & - & - & 1 & - & $\left({ }^{7}\right)$ & - & $\left({ }^{7}\right)$ & 1 & - & - & 3 & - & $\left({ }^{7}\right)$ & - & 7 \\
\hline $2003 \ldots \ldots . . .$. & - & - & 1 & - & - & - & - & - & - & - & 3 & - & $\left({ }^{7}\right)$ & - & 5 \\
\hline Total $^{3}$.. & 2,311 & 788 & 247 & 2,669 & 1,391 & 265 & 30 & 467 & 354 & 28 & 1,481 & 192 & 2,141 & 32 & 12,396 \\
\hline
\end{tabular}

1"Other" includes known end uses not falling into specified end-use categories.

2"Unknown" means undetermined end uses.

${ }^{3}$ Entries in column or row may not add to the total shown because of independent rounding and because data are rounded to no more than three significant digits.

${ }^{4}$ The total U.S. end uses in this table 3 are not exactly equivalent to the U.S. apparent consumption totals in table 2 because table 2 includes changes in government and industry stocks where available and because table 3 excludes amounts smaller than $500 \mathrm{t}$.

${ }^{5}$ The end use was included with "Other" for this year.

6"Thermal insulation" was included with "Electrical insulation" for this year.

${ }^{7} \mathrm{No}$ value is shown for this end use because the amount was less than $500 \mathrm{t}$. 


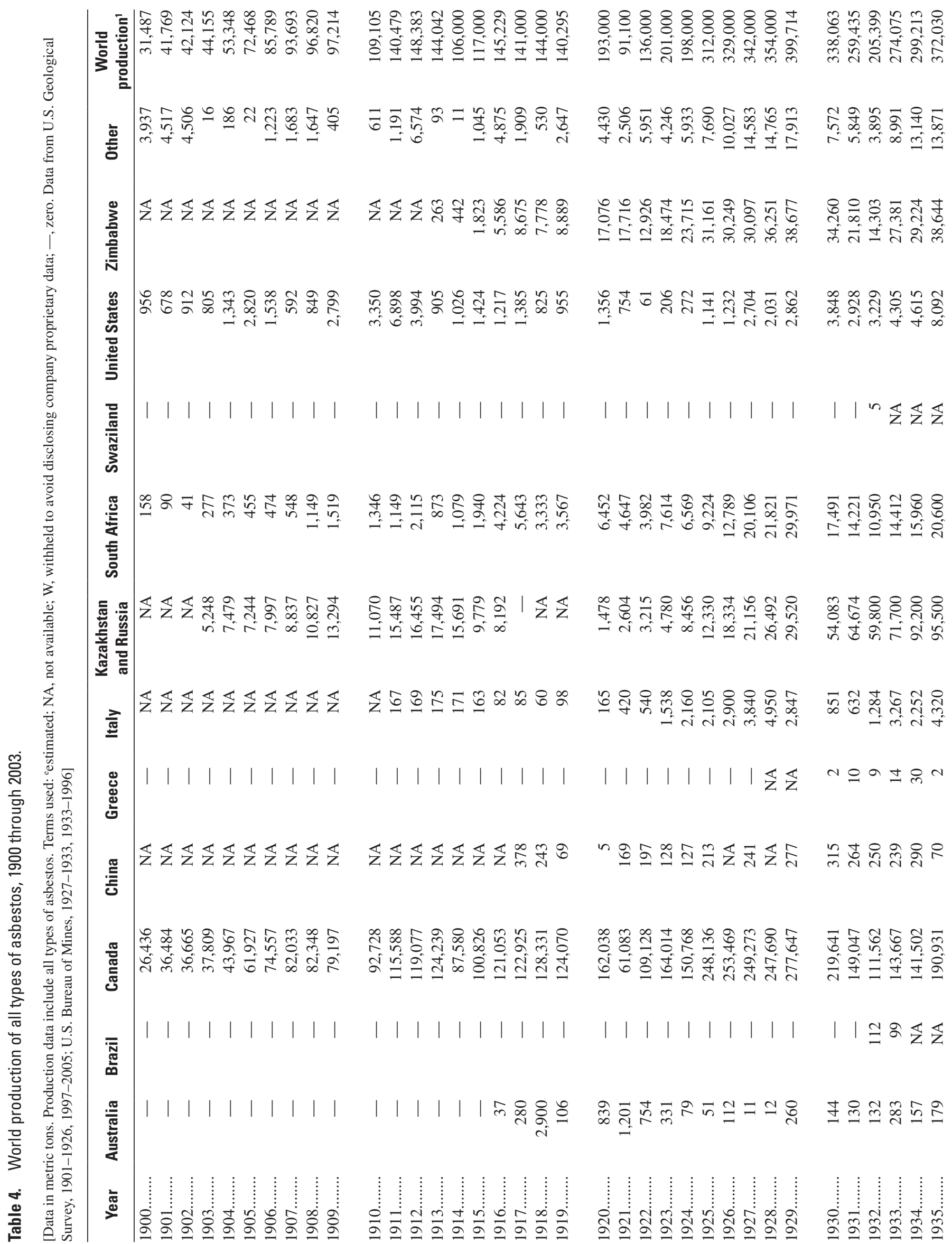




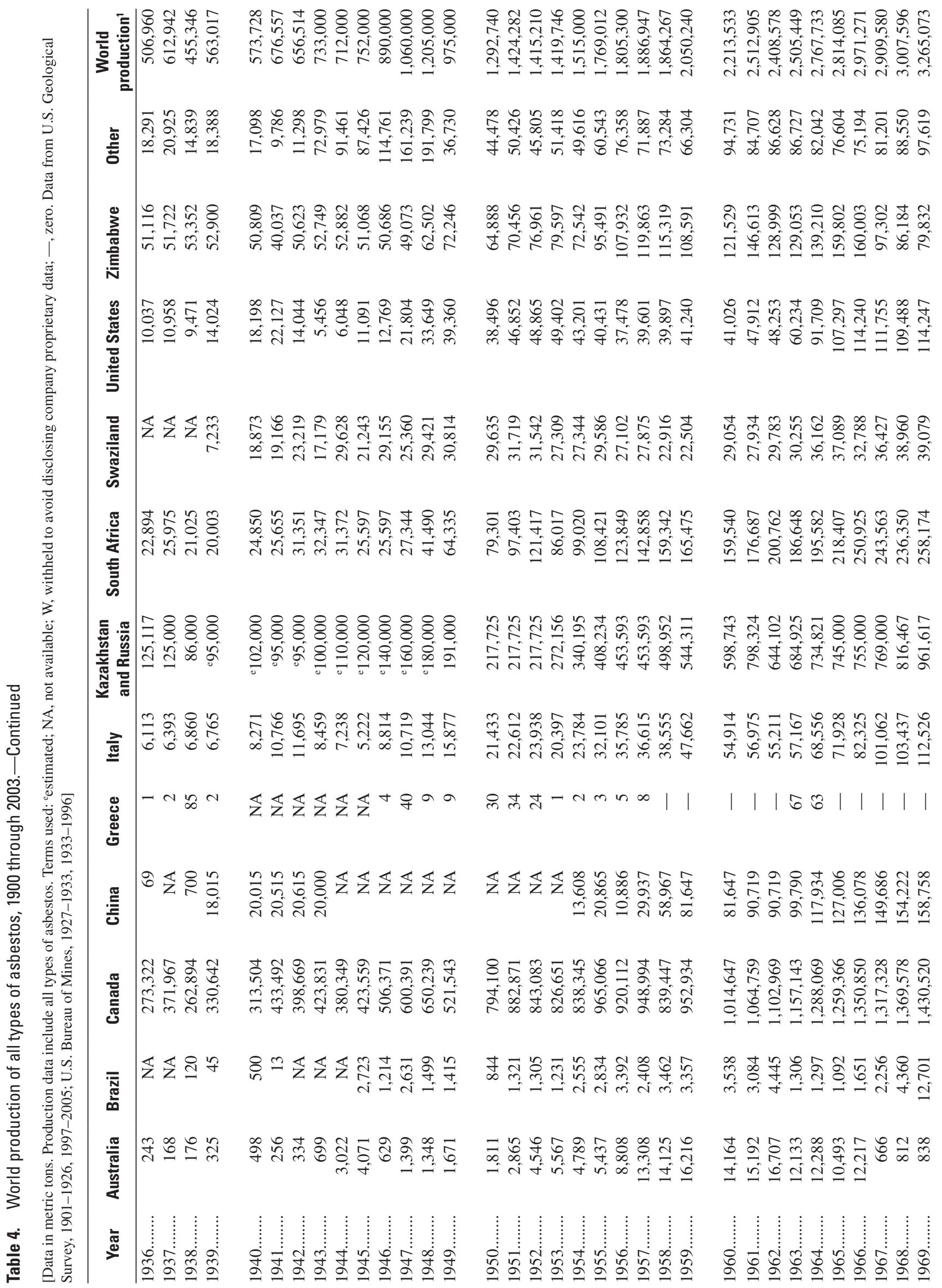




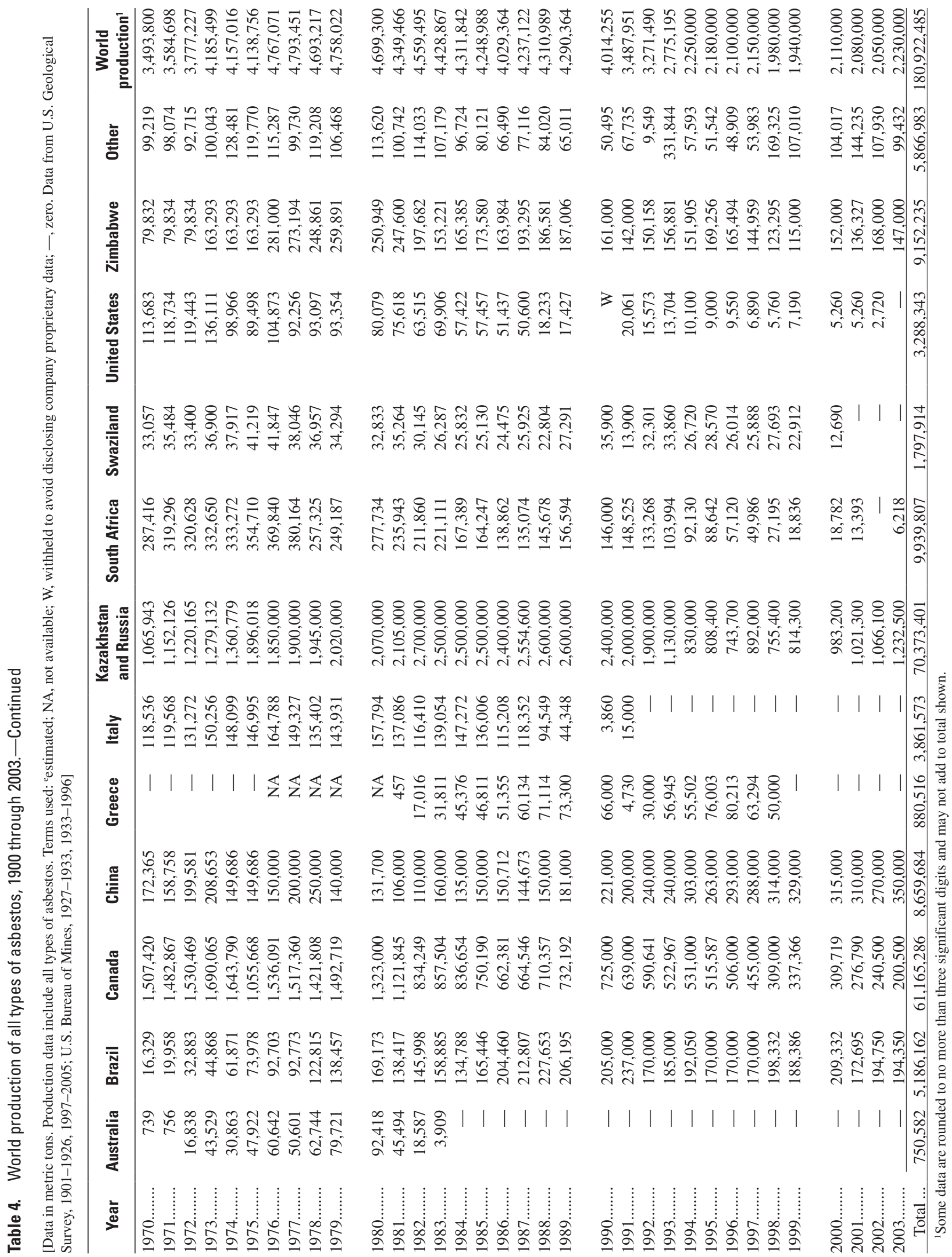




\section{Appendix. World Asbestos Production, Trade, and Consumption from 1920 through 2003}

The appendix consists of tables A1-A19, which provide estimates of consumption by country and region for selected years from 1920 through 2003. For consistency, the export, import, and production data for 1920-1997 (tables A1-A13) were taken from the "Statistical Summary of the Mineral Industry" and "World Mineral Statistics" and their predecessor reports by the British Geological Survey and its forerunners. After 1997, some production and trade data were not available in these publications, and so production data were taken from the U.S. Geological Survey "Minerals Yearbook 2004" chapter on asbestos (Virta, 2005a), and trade data were taken from the United Nations Statistics Division (2005) for tables A14-A19. Headnotes indicate the data sources for each table.

Apparent consumption was estimated as production plus imports minus exports. Changes in government and industry stocks were not included in the calculation because they were not available for most countries during most of this time period.

Data in the appendix tables are presented for individual countries and regions. To form the regions, countries are grouped by continent with a few exceptions. Middle Eastern countries are grouped with Asia. Eastern countries of the former Soviet Union, despite being in Asia, are included in Europe so as to be grouped with Russia and other western countries of the former Soviet Union and to facilitate comparisons of data for the same region at different times.

Many country names changed between 1920 and 2003. With only a few exceptions, the country name corresponding to the table year was used. For clarification, name changes for countries that appear in the appendix are given in footnotes in the first table after the change took place. Country name changes noted in the appendix are also summarized below chronologically:

- Netherlands East Indies and Dutch Indies became Indonesia after 1945.

- Germany was divided into East and West Germany from 1949 to 1990.

- Belgian Congo became Zaire between 1960 and 1998 and the Democratic Republic of the Congo [or Congo (Kinshasa)] after 1998.

- Bechuanaland became Botswana after 1966.

- Dutch Guiana and Netherlands Guiana became Suriname after 1975.

- Southern Rhodesia became Zimbabwe after 1980.

- The Soviet Union was dissolved in 1991. After 1991, asbestos trade data became available for the following countries that formerly were part of the Soviet Union: Armenia, Azerbaijan, Belarus, Estonia, Georgia, Kazakhstan, Kyrgyzstan, Latvia, Lithuania, Moldova, Russia, Tajikistan, Turkmenistan, Ukraine, and Uzbekistan. Both Asian and European countries of the former Soviet Union are listed in tables A11-A19 under Europe to facilitate comparison of regional totals for different time periods. Kazakhstan and Russia accounted for all asbestos production and most of the asbestos trade for the Soviet Union before 1995 (tables A1-A10).

- Yugoslavia was divided into Bosnia, Croatia, Herzegovina, Macedonia, Serbia, and Slovenia in 1991.

- Czechoslovakia was divided into the Czech Republic and Slovakia in 1993. 
Table A1. Asbestos production, trade, and consumption in 1920.

[Data in metric tons. Term used: —, zero. Data are unrounded but are believed to be accurate to no more than three significant digits. Production, import, and export data from Great Britain Imperial Mineral Resources Bureau, 1924]

\begin{tabular}{|c|c|c|c|c|}
\hline Region and country & Production & Imports & Exports & $\begin{array}{c}\text { Apparent } \\
\text { consumption' }\end{array}$ \\
\hline \multicolumn{5}{|l|}{ Africa: } \\
\hline 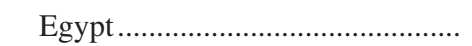 & - & 297 & - & 297 \\
\hline 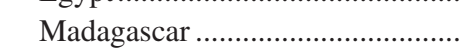 & 1 & - & - & 1 \\
\hline 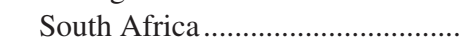 & 6,244 & - & 7,567 & $-1,323$ \\
\hline Southern Rhodesia ............................. & 17,075 & - & 13,845 & 3,230 \\
\hline Total . & 23,320 & 297 & 21,412 & 2,205 \\
\hline \multicolumn{5}{|l|}{ Asia and the Middle East: } \\
\hline China ........... & 5 & - & 5 & - \\
\hline India & 1,847 & - & - & 1,847 \\
\hline 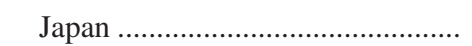 & - & 4,965 & - & 4,965 \\
\hline Total . & 1,852 & 4,965 & 5 & 6,812 \\
\hline \multicolumn{5}{|l|}{ Central and North America: } \\
\hline Canada.......................... & 153,712 & - & 173,536 & $-19,824$ \\
\hline 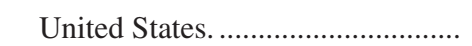 & 1,495 & 150,829 & 558 & 151,766 \\
\hline Total .............. & 155,206 & 150,829 & 174,094 & 131,942 \\
\hline \multicolumn{5}{|l|}{ Europe: } \\
\hline Austria.. & - & 941 & - & 941 \\
\hline Cyprus ................. & 925 & - & 910 & 15 \\
\hline Czechoslovakia ......... & - & 517 & 1 & 516 \\
\hline 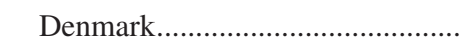 & - & 133 & - & 133 \\
\hline 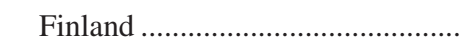 & - & 24 & - & 24 \\
\hline France ........................ & 445 & - & - & 445 \\
\hline 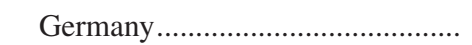 & 28 & 6,828 & 209 & 6,647 \\
\hline Italy & 166 & 3,966 & 294 & 3,838 \\
\hline 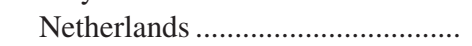 & - & 1,270 & 111 & 1,159 \\
\hline 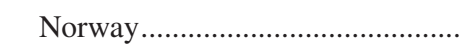 & - & 381 & - & 381 \\
\hline 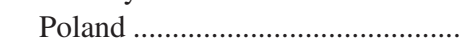 & - & 241 & - & 241 \\
\hline 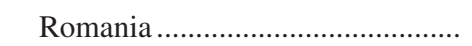 & - & 14 & - & 14 \\
\hline Soviet Union $^{2} \ldots \ldots \ldots \ldots \ldots \ldots \ldots \ldots \ldots \ldots$ & 1,629 & - & - & 1,629 \\
\hline 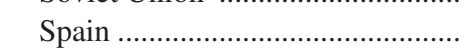 & - & 1,137 & - & 1,137 \\
\hline 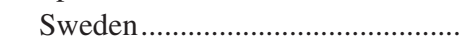 & - & 425 & 88 & 336 \\
\hline 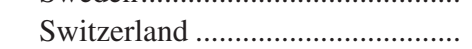 & - & 2,265 & 15 & 2,249 \\
\hline 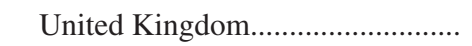 & - & 21,291 & 92 & 21,199 \\
\hline 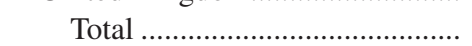 & 3,193 & 39,433 & 1,721 & 40,905 \\
\hline \multicolumn{5}{|l|}{ Oceania: } \\
\hline 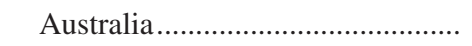 & 839 & - & - & 839 \\
\hline 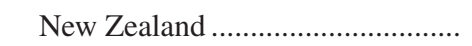 & 2 & - & - & 2 \\
\hline 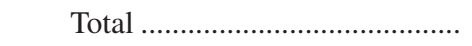 & 841 & - & - & 841 \\
\hline \multicolumn{5}{|l|}{ South America: } \\
\hline Argentina......... & - & 708 & - & 708 \\
\hline Brazil ................ & 1 & 205 & 1 & 205 \\
\hline 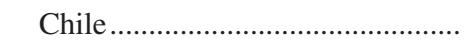 & - & 252 & 2 & 250 \\
\hline Total .................. & 1 & 1,165 & 3 & 1,163 \\
\hline Grand total .............................. & 184,413 & 196,689 & 197,235 & 183,868 \\
\hline
\end{tabular}

\footnotetext{
${ }^{1}$ Apparent consumption calculated as production plus imports minus exports, not adjusted to account for changes in government and industry stocks. Negative values indicate shipments from stocks.
}

${ }^{2}$ Combined production of Kazakhstan and Russia. 
Table A2. Asbestos production, trade, and consumption in 1930.

[Data in metric tons. Terms used: NA, not available; - , zero. Data are unrounded but are believed to be accurate to no more than three significant digits. Production, import, and export data from Great Britain Imperial Institute, 1932]

\begin{tabular}{|c|c|c|c|c|}
\hline Region and country & Production & Imports & Exports & $\begin{array}{c}\text { Apparent } \\
\text { consumption' }\end{array}$ \\
\hline \multicolumn{5}{|l|}{ Africa: } \\
\hline 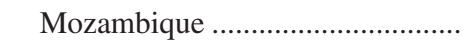 & 16 & - & - & 16 \\
\hline 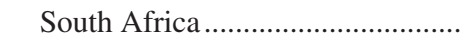 & 23,452 & - & 10,928 & 12,524 \\
\hline 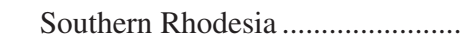 & 34,260 & 一 & 32,048 & 2,212 \\
\hline 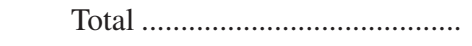 & 57,728 & - & 42,976 & 14,752 \\
\hline \multicolumn{5}{|l|}{ Asia and the Middle East: } \\
\hline China ................................... & 315 & - & - & 315 \\
\hline India ........ & 34 & - & - & 34 \\
\hline Iraq $\ldots \ldots \ldots \ldots \ldots$ & - & 34 & - & 34 \\
\hline Japan ............................... & 1,016 & 10,177 & NA & 11,193 \\
\hline Netherlands East Indies.................. & - & 6 & - & 6 \\
\hline Total .. & 1,364 & 10,217 & - & 11,581 \\
\hline \multicolumn{5}{|l|}{ Central and North America: } \\
\hline 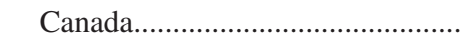 & 255,066 & - & 213,632 & 41,433 \\
\hline 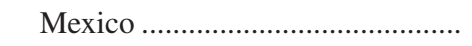 & - & 390 & - & 390 \\
\hline 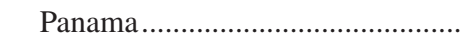 & - & 25 & - & 25 \\
\hline 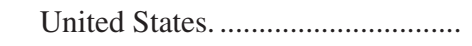 & 3,849 & 189,304 & 699 & 192,454 \\
\hline 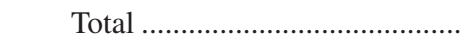 & 258,914 & 189,720 & 214,331 & 234,303 \\
\hline \multicolumn{5}{|l|}{ Europe: } \\
\hline 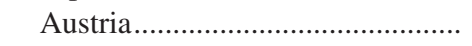 & - & 5,111 & 116 & 4,996 \\
\hline Belgium and Luxembourg ............ & - & 19,050 & 241 & 18,809 \\
\hline 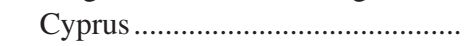 & 7,372 & 4,855 & 5,485 & 6,742 \\
\hline 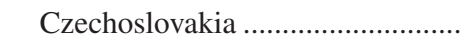 & - & - & 268 & -268 \\
\hline 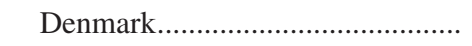 & - & 1,029 & - & 1,029 \\
\hline 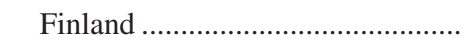 & 1,078 & 344 & - & 1,422 \\
\hline 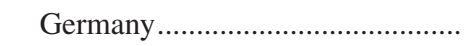 & - & 14,107 & 398 & 13,709 \\
\hline 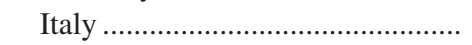 & 721 & 6,576 & 355 & 6,942 \\
\hline 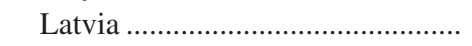 & - & 108 & - & 108 \\
\hline 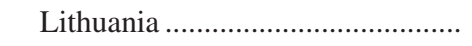 & - & 74 & - & 74 \\
\hline 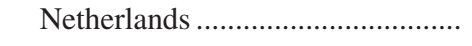 & - & 252 & 231 & 21 \\
\hline 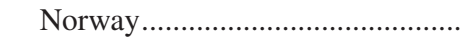 & - & 1,453 & 一 & 1,453 \\
\hline 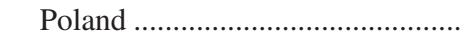 & - & 1,235 & 一 & 1,235 \\
\hline 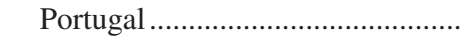 & - & 59 & - & 59 \\
\hline Romania & - & 68 & 一 & 68 \\
\hline 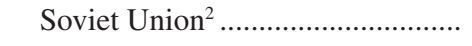 & 54,080 & 一 & 15,748 & 38,332 \\
\hline 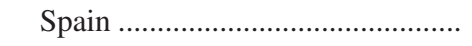 & - & 6,652 & 30 & 6,621 \\
\hline Sweden & - & 1,062 & 1 & 1,061 \\
\hline Switzerland .......... & - & 813 & 8 & 805 \\
\hline 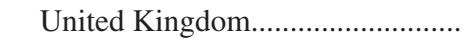 & - & 23,938 & 721 & 23,217 \\
\hline Yugoslavia... & - & 1,045 & - & 1,045 \\
\hline Total ......... & 63,251 & 87,832 & 23,603 & 127,481 \\
\hline Oceania: Australia..... & 83 & NA & - & 83 \\
\hline
\end{tabular}


Table A2. Asbestos production, trade, and consumption in 1930.-Continued

[Data in metric tons. Terms used: NA, not available; - , zero. Data are unrounded but are believed to be accurate to no more than three significant digits. Production, import, and export data from Great Britain Imperial Institute, 1932]

\begin{tabular}{|c|c|c|c|c|}
\hline Region and country & Production & Imports & Exports & $\begin{array}{c}\text { Apparent } \\
\text { consumption' }\end{array}$ \\
\hline \multicolumn{5}{|l|}{ South America: } \\
\hline Brazil............ & - & 136 & - & 136 \\
\hline Chile.... & - & 127 & - & 127 \\
\hline Colombia.. & - & 77 & - & 77 \\
\hline Total ............... & - & 340 & - & 340 \\
\hline Grand total . & 381,341 & 288,109 & 280,910 & 388,541 \\
\hline
\end{tabular}

\footnotetext{
${ }^{1}$ Apparent consumption calculated as production plus imports minus exports, not adjusted to account for changes in government and industry stocks. Negative values indicate shipments from stocks.
}

${ }^{2}$ Combined production and exports of Kazakhstan and Russia. 
Table A3. Asbestos production, trade, and consumption in 1940.

[Data in metric tons. Terms used: NA, not available; - , zero. Data are unrounded but are believed to be accurate to no more than three significant digits. Production, import, and export data from Great Britain Imperial Institute, 1948]

\begin{tabular}{|c|c|c|c|c|}
\hline Region and country & Production & Imports & Exports & $\begin{array}{c}\text { Apparent } \\
\text { consumption }^{1}\end{array}$ \\
\hline \multicolumn{5}{|l|}{ Africa: } \\
\hline Algeria... & - & 5 & - & 5 \\
\hline 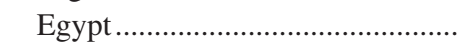 & - & 120 & - & 120 \\
\hline 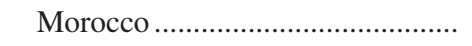 & 203 & - & - & 203 \\
\hline 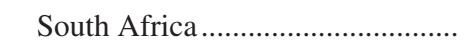 & 24,851 & - & 39,448 & $-14,597$ \\
\hline 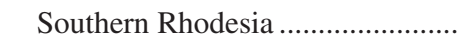 & 50,812 & - & 52,520 & $-1,708$ \\
\hline 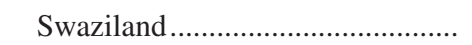 & 18,874 & - & 17,782 & 1,092 \\
\hline Total . & 94,740 & 125 & 109,750 & $-14,885$ \\
\hline \multicolumn{5}{|l|}{ Asia and the Middle East: } \\
\hline China.... & 102 & 39 & - & 140 \\
\hline India & 297 & 5,257 & - & 5,554 \\
\hline 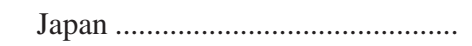 & 1,524 & 25,403 & 254 & 26,673 \\
\hline 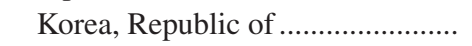 & 508 & 5,081 & - & 5,589 \\
\hline Netherlands East Indies..................... & - & 287 & - & 287 \\
\hline 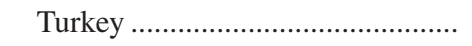 & 88 & 一 & - & 88 \\
\hline 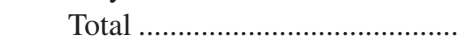 & 2,519 & 36,065 & 254 & 38,330 \\
\hline \multicolumn{5}{|l|}{ Central and North America: } \\
\hline Canada.... & 320,514 & - & 305,351 & 15,162 \\
\hline Costa Rica. & - & 20 & - & 20 \\
\hline Mexico ........ & - & 947 & - & 947 \\
\hline United States & 17,396 & 223,735 & 4,059 & 237,071 \\
\hline Total . & 337,909 & 224,702 & 309,411 & 253,201 \\
\hline \multicolumn{5}{|l|}{ Europe: } \\
\hline$\ldots \ldots \ldots \ldots . . .$. & - & 508 & 5 & 503 \\
\hline Belgium and Luxembourg ............ & - & 254 & 508 & -254 \\
\hline 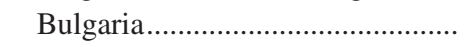 & - & 5 & - & 5 \\
\hline 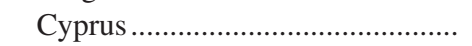 & 7,967 & - & 8,637 & -670 \\
\hline 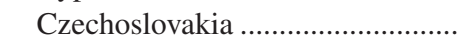 & NA & 5,081 & 508 & 4,572 \\
\hline 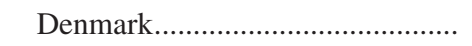 & - & 512 & - & 512 \\
\hline 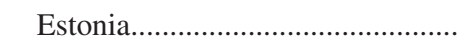 & - & 102 & - & 102 \\
\hline 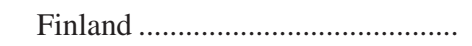 & 5,338 & 51 & 1,563 & 3,826 \\
\hline 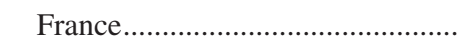 & 5,081 & 14,050 & - & 19,130 \\
\hline 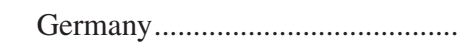 & - & 11,555 & 374 & 11,181 \\
\hline 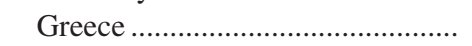 & 20 & 71 & - & 91 \\
\hline 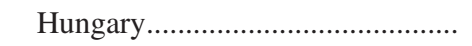 & - & 508 & NA & 508 \\
\hline Iceland............. & - & 15 & - & 15 \\
\hline 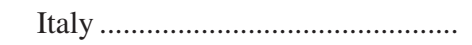 & 8,269 & 5,748 & 546 & 13,471 \\
\hline 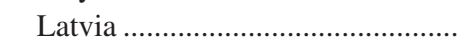 & - & 102 & - & 102 \\
\hline 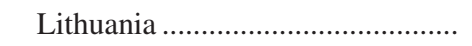 & - & 51 & - & 51 \\
\hline 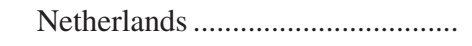 & - & 1,040 & - & 1,040 \\
\hline 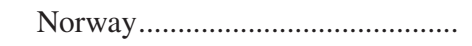 & - & 155 & - & 155 \\
\hline 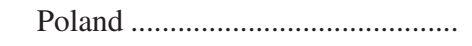 & - & 1,016 & 20 & 996 \\
\hline 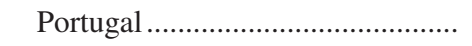 & 102 & 501 & 20 & 582 \\
\hline 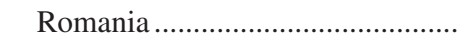 & - & 61 & - & 61 \\
\hline 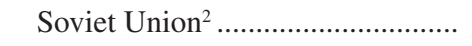 & 101,610 & - & 30,483 & 71,127 \\
\hline 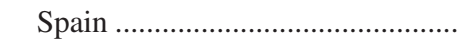 & - & 1,793 & 5 & 1,788 \\
\hline 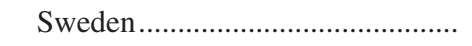 & - & 2,880 & 2 & 2,878 \\
\hline 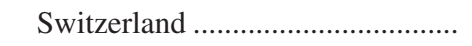 & - & 2,086 & 9 & 2,077 \\
\hline
\end{tabular}


Table A3. Asbestos production, trade, and consumption in 1940.-Continued

[Data in metric tons. Terms used: NA, not available; - , zero. Data are unrounded but are believed to be accurate to no more than three significant digits. Production, import, and export data from Great Britain Imperial Institute, 1948]

\begin{tabular}{|c|c|c|c|c|}
\hline Region and country & Production & Imports & Exports & $\begin{array}{c}\text { Apparent } \\
\text { consumption }\end{array}$ \\
\hline \multicolumn{5}{|l|}{ Europe (continued): } \\
\hline United Kingdom... & - & 95,392 & 384 & 95,008 \\
\hline 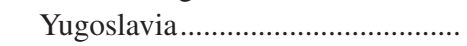 & - & 102 & 20 & 81 \\
\hline Total .................... & 128,386 & 143,639 & 43,085 & 228,941 \\
\hline \multicolumn{5}{|l|}{ Oceania: } \\
\hline 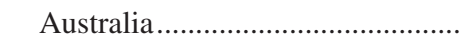 & 497 & 14,324 & NA & 14,821 \\
\hline 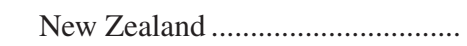 & 3 & 795 & 3 & 795 \\
\hline Total ................. & 500 & 15,119 & 3 & 15,615 \\
\hline \multicolumn{5}{|l|}{ South America: } \\
\hline 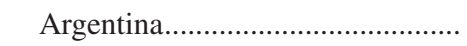 & 150 & - & - & 150 \\
\hline 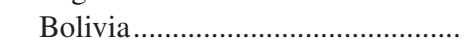 & 70 & 70 & 70 & 70 \\
\hline Brazil............ & 508 & 51 & - & 559 \\
\hline 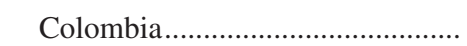 & - & 79 & - & 79 \\
\hline 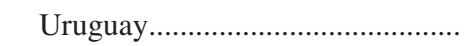 & - & 192 & - & 192 \\
\hline 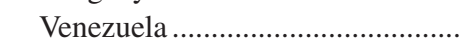 & 20 & 28 & 20 & 28 \\
\hline 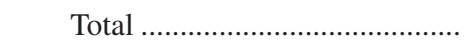 & 749 & 421 & 90 & 1,079 \\
\hline 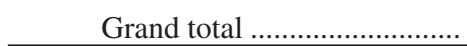 & 564,803 & 420,071 & 462,593 & 522,282 \\
\hline
\end{tabular}

${ }^{1}$ Apparent consumption calculated as production plus imports minus exports, not adjusted to account for changes in government and industry stocks. Negative values indicate shipments from stocks.

${ }^{2}$ Combined production and exports of Kazakhstan and Russia. 
Table A4. Asbestos production, trade, and consumption in 1950.

[Data in metric tons. Terms used: NA, not available; - , zero. Data are unrounded but are believed to be accurate to no more than three significant digits. Production, import, and export data from Great Britain Colonial Geological Surveys, 1956]

\begin{tabular}{|c|c|c|c|c|}
\hline Region and country & Production & Imports & Exports & $\begin{array}{c}\text { Apparent } \\
\text { consumption' }\end{array}$ \\
\hline \multicolumn{5}{|l|}{ Africa: } \\
\hline Algeria.. & - & 1,552 & - & 1,552 \\
\hline 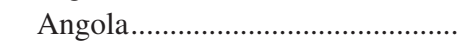 & - & 49 & - & 49 \\
\hline 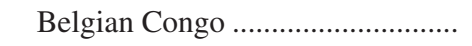 & - & 1,344 & - & 1,344 \\
\hline 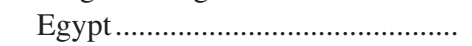 & 260 & 868 & 44 & 1,084 \\
\hline 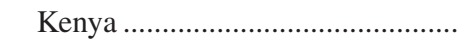 & 229 & - & NA & 229 \\
\hline 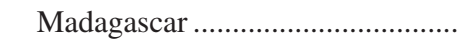 & - & - & 1 & -1 \\
\hline 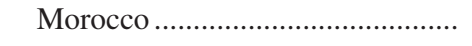 & 511 & 475 & 156 & 829 \\
\hline 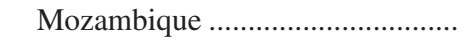 & - & 276 & - & 276 \\
\hline 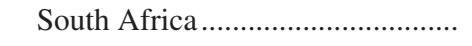 & 79,305 & - & 92,155 & $-12,851$ \\
\hline 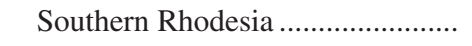 & 64,891 & - & 66,935 & $-2,043$ \\
\hline 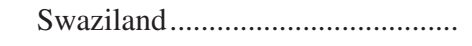 & 29,637 & - & 25,403 & 4,234 \\
\hline 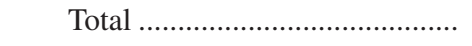 & 174,832 & 4,563 & 184,693 & $-5,298$ \\
\hline \multicolumn{5}{|l|}{ Asia and the Middle East: } \\
\hline China ........ & 102 & - & - & 102 \\
\hline India ..... & 211 & 10,957 & 8 & 11,160 \\
\hline Indonesia $^{2}$. & - & 39 & - & 39 \\
\hline Iraq ................. & - & 23 & - & 23 \\
\hline Japan ............. & 5,665 & 6,690 & 110 & 12,245 \\
\hline 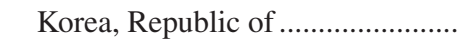 & 610 & - & - & 610 \\
\hline 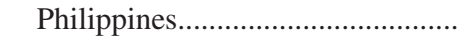 & - & 657 & - & 657 \\
\hline Taiwan (Formosa) .............................. & 218 & 102 & - & 320 \\
\hline 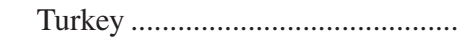 & 245 & 10 & 28 & 227 \\
\hline 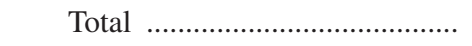 & 7,051 & 18,478 & 146 & 25,383 \\
\hline \multicolumn{5}{|l|}{ Central and North America: } \\
\hline 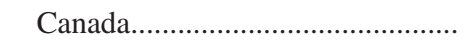 & 794,140 & - & 752,983 & 41,157 \\
\hline 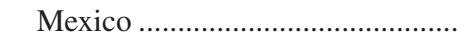 & - & 5,429 & - & 5,429 \\
\hline 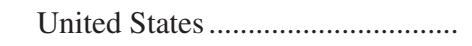 & 37,522 & 639,755 & 17,148 & 660,129 \\
\hline 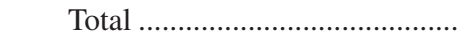 & 831,662 & 645,184 & 770,131 & 706,715 \\
\hline \multicolumn{5}{|l|}{ Europe: } \\
\hline 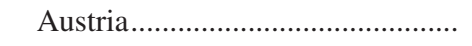 & - & 3,496 & 21 & 3,475 \\
\hline Belgium and Luxembourg ............. & - & 21,856 & 636 & 21,220 \\
\hline 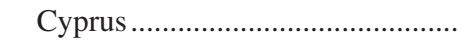 & 14,990 & - & 15,720 & -731 \\
\hline 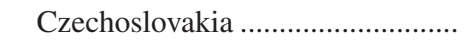 & NA & 15,242 & - & 15,242 \\
\hline 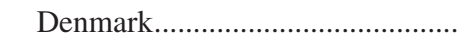 & - & 9,986 & - & 9,986 \\
\hline 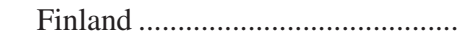 & 10,949 & 988 & 2,300 & 9,637 \\
\hline 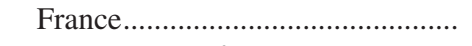 & 7,456 & 33,560 & 2,095 & 38,921 \\
\hline 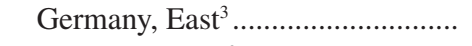 & - & 13,858 & 15 & 13,842 \\
\hline 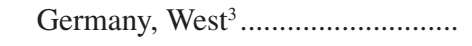 & - & 80,000 & - & 80,000 \\
\hline 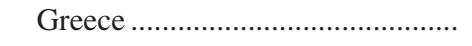 & 30 & 178 & - & 208 \\
\hline 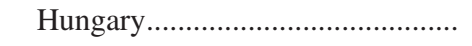 & - & 5,081 & - & 5,081 \\
\hline 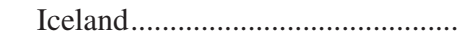 & - & 31 & - & 31 \\
\hline Italy & 21,434 & 6,265 & 2,886 & 24,813 \\
\hline 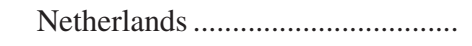 & - & 6,935 & 8 & 6,927 \\
\hline 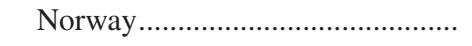 & - & 2,676 & - & 2,676 \\
\hline Poland ...... & - & 5,081 & - & 5,081 \\
\hline Portugal ........ & 257 & 2,323 & 169 & 2,411 \\
\hline 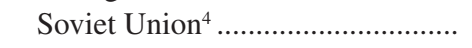 & 217,746 & NA & 81,288 & 136,458 \\
\hline
\end{tabular}


Table A4. Asbestos production, trade, and consumption in 1950.-Continued

[Data in metric tons. Terms used: NA, not available; — , zero. Data are unrounded but are believed to be accurate to no more than three significant digits. Production, import, and export data from Great Britain Colonial Geological Surveys, 1956]

\begin{tabular}{|c|c|c|c|c|}
\hline Region and country & Production & Imports & Exports & $\begin{array}{c}\text { Apparent } \\
\text { consumption' }\end{array}$ \\
\hline \multicolumn{5}{|l|}{ Europe (continued): } \\
\hline 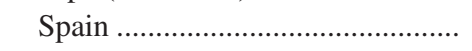 & 42 & 4,384 & 2 & 4,424 \\
\hline Sweden ......................... & - & 10,246 & 244 & 10,002 \\
\hline 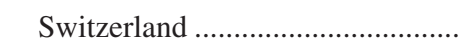 & - & 4,298 & 92 & 4,206 \\
\hline United Kingdom.... & - & 111,261 & 3,655 & 107,606 \\
\hline Yugoslavia.. & 958 & 3,956 & 35 & 4,879 \\
\hline Total ... & 273,862 & 341,701 & 109,167 & 506,396 \\
\hline \multicolumn{5}{|l|}{ Oceania: } \\
\hline Australia ............... & 1,643 & 16,824 & 285 & 18,182 \\
\hline New Zealand ..... & 42 & 3,846 & - & 3,888 \\
\hline Total ................... & 1,685 & 20,670 & 285 & 22,070 \\
\hline \multicolumn{5}{|l|}{ South America: } \\
\hline 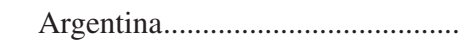 & NA & - & - & NA \\
\hline 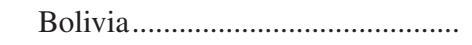 & 166 & - & 166 & - \\
\hline 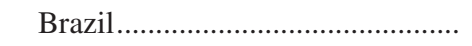 & 844 & 8,435 & - & 9,279 \\
\hline Chile & 172 & 234 & - & 405 \\
\hline 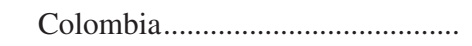 & - & NA & - & NA \\
\hline 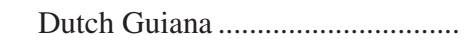 & - & NA & - & NA \\
\hline 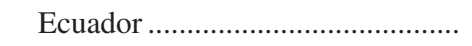 & - & NA & - & NA \\
\hline Peru & - & 811 & - & 811 \\
\hline 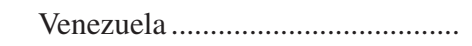 & 190 & 999 & 20 & 1,169 \\
\hline 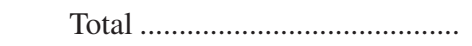 & 1,372 & 10,478 & 186 & 11,664 \\
\hline Grand total . & $1,290,463$ & $1,041,073$ & $1,064,608$ & $1,266,929$ \\
\hline
\end{tabular}

${ }^{1}$ Apparent consumption calculated as production plus imports minus exports, not adjusted to account for changes in government and industry stocks. Negative values indicate shipments from stocks.

${ }^{2}$ Netherlands East Indies and Dutch Indies became Indonesia after 1945.

${ }^{3}$ Germany was divided into East and West Germany from 1949 to 1990.

${ }^{4}$ Combined production and exports of Kazakhstan and Russia. 
Table A5. Asbestos production, trade, and consumption in 1960.

[Data in metric tons. Terms used: NA, not available; —, zero. Data are unrounded but are believed to be accurate to no more than three significant digits. Production, import, and export data from Great Britain Institute of Geological Sciences, Overseas Division, 1967]

\begin{tabular}{|c|c|c|c|c|}
\hline Region and country & Production & Imports & Exports & $\begin{array}{c}\text { Apparent } \\
\text { consumption } 1\end{array}$ \\
\hline \multicolumn{5}{|l|}{ Africa: } \\
\hline 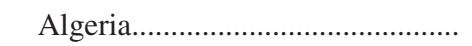 & - & 6,189 & - & 6,189 \\
\hline 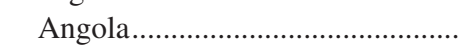 & - & 819 & - & 819 \\
\hline Bechuanaland... & 1,163 & - & - & 1,163 \\
\hline 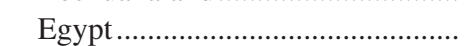 & 450 & 6,583 & - & 7,033 \\
\hline Kenya .............. & 106 & - & 29 & 76 \\
\hline 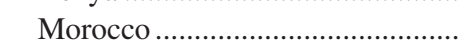 & - & 2,676 & - & 2,676 \\
\hline 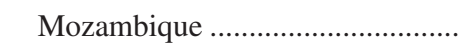 & 20 & 720 & 80 & 660 \\
\hline 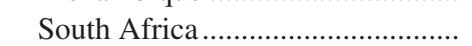 & 159,551 & NA & 193,696 & $-34,145$ \\
\hline Southern Rhodesia ............................. & 121,537 & - & 116,060 & 5,477 \\
\hline 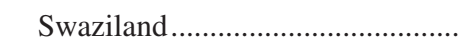 & 29,055 & - & 25,403 & 3,653 \\
\hline 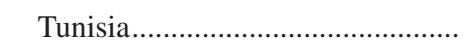 & - & 2 & - & 2 \\
\hline 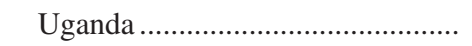 & - & 830 & - & 830 \\
\hline 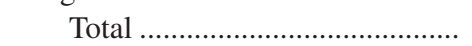 & 311,883 & 17,820 & 335,268 & $-5,565$ \\
\hline \multicolumn{5}{|l|}{ Asia and the Middle East: } \\
\hline Burma..... & - & 468 & - & 468 \\
\hline China ....... & 81,288 & - & - & 81,288 \\
\hline Hong Kong....... & - & 22 & - & 22 \\
\hline India & 1,711 & 21,967 & 26 & 23,652 \\
\hline Indonesia..... & - & 588 & - & 588 \\
\hline Iran ................ & - & 1,246 & - & 1,246 \\
\hline Iraq ....... & - & 450 & - & 450 \\
\hline Israel...... & - & 6,615 & - & 6,615 \\
\hline Japan ........................ & 15,461 & 77,059 & 37 & 92,483 \\
\hline Korea, Republic of.. & 631 & - & - & 631 \\
\hline 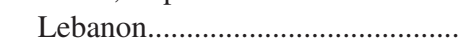 & - & 2,258 & - & 2,258 \\
\hline 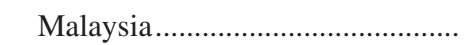 & - & 2,868 & - & 2,868 \\
\hline 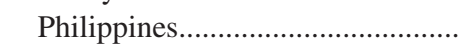 & 33 & 1,236 & - & 1,268 \\
\hline 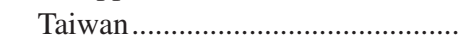 & 440 & 1,047 & - & 1,487 \\
\hline 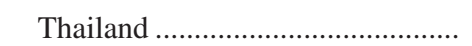 & - & 6,433 & - & 6,433 \\
\hline 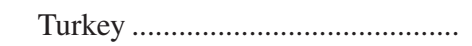 & 216 & 470 & 5 & 682 \\
\hline Total & 99,780 & 122,728 & 68 & 222,440 \\
\hline \multicolumn{5}{|l|}{ Central and North America: } \\
\hline 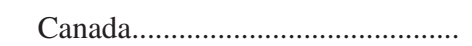 & $1,014,699$ & NA & 969,372 & 45,327 \\
\hline 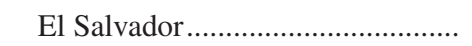 & - & 227 & - & 227 \\
\hline 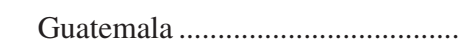 & - & 226 & - & 226 \\
\hline Jamaica & - & 35 & - & 35 \\
\hline 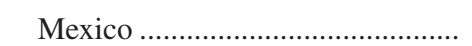 & - & 13,421 & - & 13,421 \\
\hline 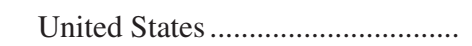 & 41,028 & 607,388 & 4,955 & 643,462 \\
\hline Total ...... & $1,055,727$ & 621,295 & 974,326 & 702,696 \\
\hline \multicolumn{5}{|l|}{ Europe: } \\
\hline 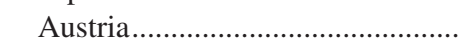 & 60 & 12,767 & 63 & 12,764 \\
\hline Belgium and Luxembourg ............ & - & 53,990 & 297 & 53,694 \\
\hline 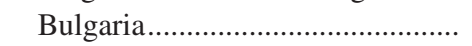 & 1,118 & - & - & 1,118 \\
\hline 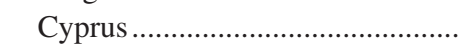 & 21,153 & - & 15,575 & 5,578 \\
\hline 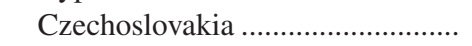 & - & 27,422 & - & 27,422 \\
\hline Denmark & - & 17,440 & 26 & 17,414 \\
\hline
\end{tabular}


Table A5. Asbestos production, trade, and consumption in 1960.-Continued

[Data in metric tons. Terms used: NA, not available; — , zero. Data are unrounded but are believed to be accurate to no more than three significant digits. Production, import, and export data from Great Britain Institute of Geological Sciences, Overseas Division, 1967]

\begin{tabular}{|c|c|c|c|c|}
\hline Region and country & Production & Imports & Exports & $\begin{array}{c}\text { Apparent } \\
\text { consumption }\end{array}$ \\
\hline \multicolumn{5}{|l|}{ Europe (continued): } \\
\hline Finland .................... & 9,556 & 4,446 & 5,551 & 8,452 \\
\hline 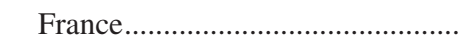 & 25,583 & 68,592 & 10,790 & 83,385 \\
\hline 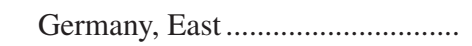 & - & 35,000 & - & 35,000 \\
\hline 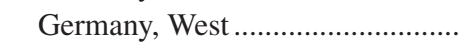 & - & 132,634 & 226 & 132,408 \\
\hline 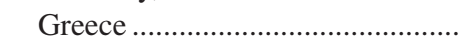 & - & 48 & - & 48 \\
\hline 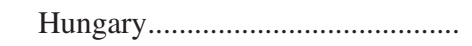 & - & 9,804 & - & 9,804 \\
\hline Iceland.... & - & 37 & - & 37 \\
\hline Italy ....... & 51,123 & 29,607 & 7,409 & 73,322 \\
\hline Netherlands ........ & - & 21,725 & 36 & 21,690 \\
\hline Norway................... & - & 6,918 & - & 6,918 \\
\hline Poland ..................... & - & 15,245 & - & 15,245 \\
\hline Portugal .......... & 131 & 2,346 & 35 & 2,443 \\
\hline 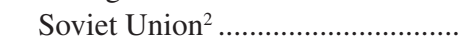 & 599,499 & - & 146,115 & 453,384 \\
\hline 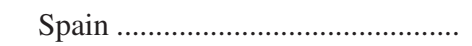 & 4 & 14,453 & - & 14,457 \\
\hline 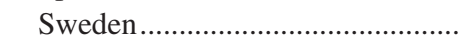 & - & 17,107 & 28 & 17,079 \\
\hline 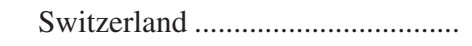 & - & 8,695 & - & 8,695 \\
\hline 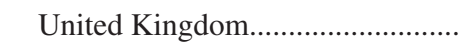 & - & 170,893 & 7,874 & 163,019 \\
\hline Yugoslavia.... & 5,416 & 8,727 & 5,217 & 8,926 \\
\hline Total ............. & 713,644 & 657,896 & 199,240 & $1,172,300$ \\
\hline \multicolumn{5}{|l|}{ Oceania: } \\
\hline Australia......... & 14,164 & 37,198 & 7,529 & 43,834 \\
\hline New Zealand .......... & 289 & 4,585 & - & 4,873 \\
\hline Total ............... & 14,453 & 41,783 & 7,529 & 48,707 \\
\hline \multicolumn{5}{|l|}{ South America: } \\
\hline Bolivia ............. & 170 & - & 170 & - \\
\hline 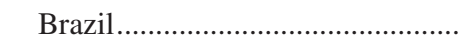 & 13,237 & 13,670 & - & 26,906 \\
\hline 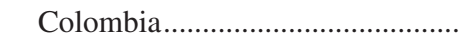 & - & 6,836 & - & 6,836 \\
\hline 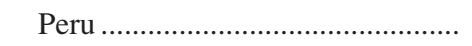 & - & 1,813 & - & 1,813 \\
\hline 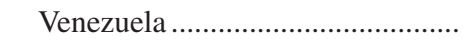 & 3,932 & 2,277 & 3,661 & 2,548 \\
\hline Total .................... & 17,339 & 24,596 & 3,831 & 38,104 \\
\hline Grand total ............................. & $2,212,825$ & $1,486,118$ & $1,520,263$ & $2,178,681$ \\
\hline
\end{tabular}

${ }^{1}$ Apparent consumption calculated as production plus imports minus exports, not adjusted to account for changes in government and industry stocks. Negative values indicate shipments from stocks.

${ }^{2}$ Combined production and exports of Kazakhstan and Russia. 
Table A6. Asbestos production, trade, and consumption in 1970.

[Data in metric tons. Terms used: NA, not available; - , zero. Data are unrounded but are believed to be accurate to no more than three significant digits. Production, import, and export data from Great Britain Institute of Geological Sciences, 1973]

\begin{tabular}{|c|c|c|c|c|}
\hline Region and country & Production & Imports & Exports & $\begin{array}{c}\text { Apparent } \\
\text { consumption }\end{array}$ \\
\hline \multicolumn{5}{|l|}{ Africa: } \\
\hline 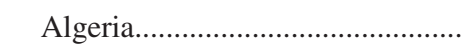 & - & 2,285 & - & 2,285 \\
\hline 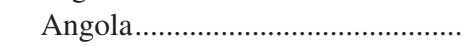 & - & 1,076 & - & 1,076 \\
\hline 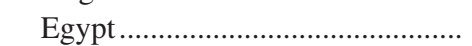 & 449 & 6,609 & - & 7,058 \\
\hline 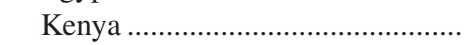 & - & 206 & - & 206 \\
\hline 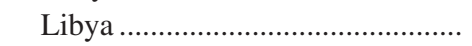 & - & 540 & - & 540 \\
\hline 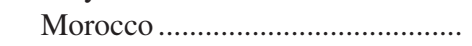 & - & 3,551 & - & 3,551 \\
\hline 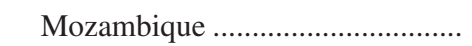 & 228 & 753 & 316 & 665 \\
\hline 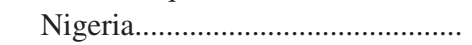 & - & 34,443 & - & 34,443 \\
\hline 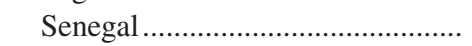 & - & 799 & - & 799 \\
\hline 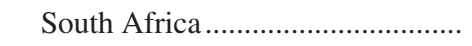 & 287,431 & 17,191 & 290,381 & 14,241 \\
\hline 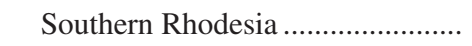 & 81,288 & - & 76,208 & 5,080 \\
\hline Swaziland .................... & 33,059 & - & 32,515 & 544 \\
\hline Tunisia.......... & - & 1,766 & - & 1,766 \\
\hline Uganda ...... & - & 2,468 & - & 2,468 \\
\hline Zambia .... & - & 15,607 & - & 15,607 \\
\hline …................... & 402,455 & 87,294 & 399,420 & 90,329 \\
\hline \multicolumn{5}{|l|}{ Asia and the Middle East: } \\
\hline 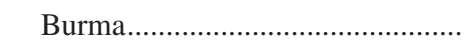 & - & 1,465 & - & 1,465 \\
\hline 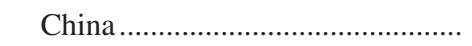 & 172,737 & - & - & 172,737 \\
\hline 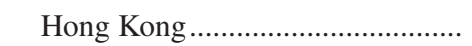 & - & 90 & - & 90 \\
\hline 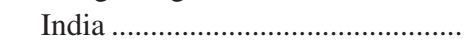 & 10,056 & 39,766 & 30 & 49,792 \\
\hline Iran & - & 11,197 & - & 11,197 \\
\hline Iraq & - & 2,000 & - & 2,000 \\
\hline 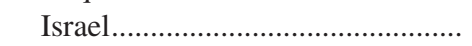 & - & 7,589 & - & 7,589 \\
\hline 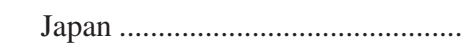 & 21,389 & 298,253 & 169 & 319,473 \\
\hline 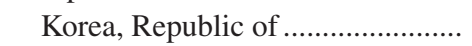 & 1,372 & 35,292 & - & 36,664 \\
\hline 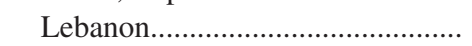 & - & 6,418 & - & 6,418 \\
\hline 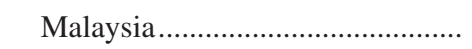 & - & 14,321 & - & 14,321 \\
\hline 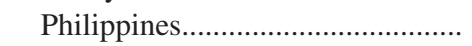 & 1,213 & 3,303 & - & 4,516 \\
\hline 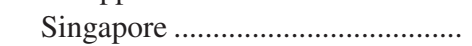 & - & 3,150 & - & 3,150 \\
\hline 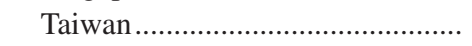 & 2,842 & 6,589 & 151 & 9,280 \\
\hline 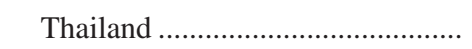 & - & 21,272 & - & 21,272 \\
\hline 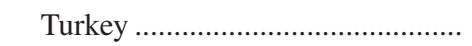 & 1,685 & 7,546 & - & 9,231 \\
\hline 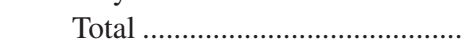 & 211,294 & 458,251 & 350 & 669,195 \\
\hline \multicolumn{5}{|l|}{ Central and North America: } \\
\hline 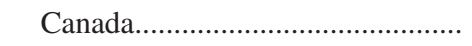 & $1,507,497$ & 5,292 & $1,417,415$ & 95,374 \\
\hline 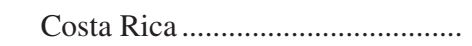 & - & 736 & - & 736 \\
\hline 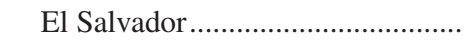 & - & 963 & - & 963 \\
\hline 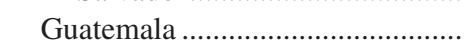 & - & 457 & - & 457 \\
\hline 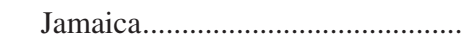 & - & 1,910 & - & 1,910 \\
\hline 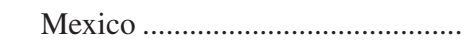 & - & 40,460 & - & 40,460 \\
\hline Netherlands Antilles........................... & - & 335 & - & 335 \\
\hline 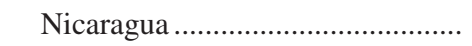 & - & 316 & - & 316 \\
\hline 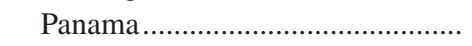 & - & 146 & - & 146 \\
\hline 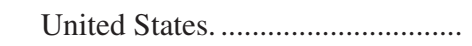 & 113,688 & 589,127 & 34,686 & 668,129 \\
\hline 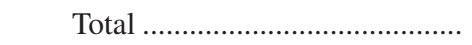 & $1,621,186$ & 639,742 & $1,452,101$ & 808,827 \\
\hline
\end{tabular}


Table A6. Asbestos production, trade, and consumption in 1970.-Continued

[Data in metric tons. Terms used: NA, not available; - , zero. Data are unrounded but are believed to be accurate to no more than three significant digits. Production, import, and export data from Great Britain Institute of Geological Sciences, 1973]

\begin{tabular}{|c|c|c|c|c|}
\hline Region and country & Production & Imports & Exports & $\begin{array}{c}\text { Apparent } \\
\text { consumption }{ }^{1}\end{array}$ \\
\hline \multicolumn{5}{|l|}{ Europe: } \\
\hline 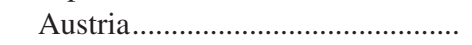 & - & 34,155 & 29 & 34,126 \\
\hline Belgium and Luxembourg ............ & - & 54,839 & 953 & 53,886 \\
\hline 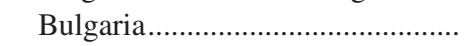 & 3,046 & - & - & 3,046 \\
\hline 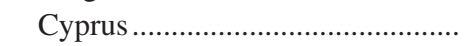 & 28,708 & - & 24,133 & 4,575 \\
\hline 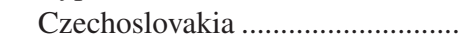 & NA & 39,017 & - & 39,017 \\
\hline 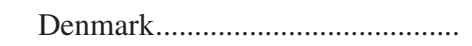 & - & 28,633 & 6 & 28,627 \\
\hline 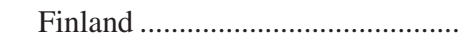 & 13,626 & 7,744 & 9,335 & 12,035 \\
\hline 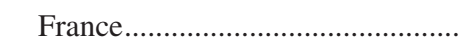 & 710 & 151,848 & 201 & 152,357 \\
\hline 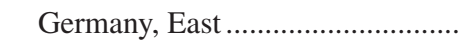 & - & 52,015 & - & 52,015 \\
\hline 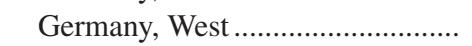 & - & 175,612 & 924 & 174,688 \\
\hline 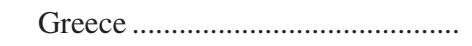 & - & 17,811 & NA & 17,811 \\
\hline 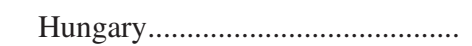 & - & 15,236 & - & 15,236 \\
\hline Iceland...................... & - & 1,028 & - & 1,028 \\
\hline Italy & 118,618 & 62,402 & 48,662 & 132,358 \\
\hline Netherlands ................. & - & 20,063 & 275 & 19,788 \\
\hline 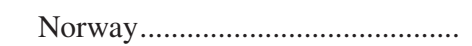 & - & 7,982 & - & 7,982 \\
\hline Poland ......................... & - & 64,385 & - & 64,385 \\
\hline 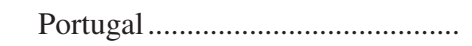 & 202 & 6,509 & 180 & 6,531 \\
\hline 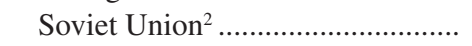 & $1,065,889$ & - & 385,300 & 680,589 \\
\hline Spain & - & 77,677 & 875 & 76,802 \\
\hline 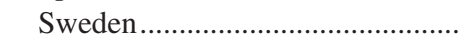 & - & 18,830 & 184 & 18,646 \\
\hline 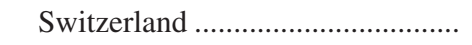 & - & 17,721 & 66 & 17,655 \\
\hline United Kingdom................................. & - & 154,636 & 4,741 & 149,895 \\
\hline Yugoslavia... & 12,105 & 28,552 & 4,666 & 35,991 \\
\hline 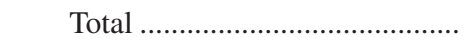 & $1,242,904$ & $1,036,695$ & 480,530 & $1,799,069$ \\
\hline \multicolumn{5}{|l|}{ Oceania: } \\
\hline Australia .......... & 740 & 68,605 & 443 & 68,902 \\
\hline New Zealand. & - & 8,662 & - & 8,662 \\
\hline Total ......... & 740 & 77,267 & 443 & 77,564 \\
\hline \multicolumn{5}{|l|}{ South America: } \\
\hline Argentina.... & 35 & 21,106 & - & 21,141 \\
\hline Bolivia ........... & - & 508 & - & 508 \\
\hline Brazil............... & 16,329 & 23,413 & 2,032 & 37,710 \\
\hline 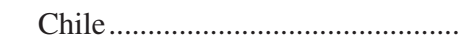 & - & 8,800 & - & 8,800 \\
\hline 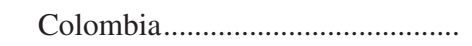 & - & 16,763 & - & 16,763 \\
\hline 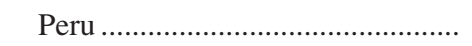 & - & 1,828 & - & 1,828 \\
\hline 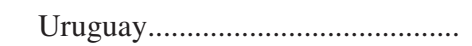 & - & 1,996 & - & 1,996 \\
\hline 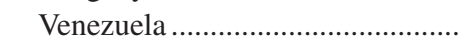 & - & 10,161 & - & 10,161 \\
\hline 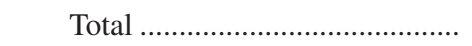 & 16,363 & 84,575 & 2,032 & 98,906 \\
\hline Grand total .............................. & $3,494,941$ & $2,383,824$ & $2,334,876$ & $3,543,889$ \\
\hline
\end{tabular}

${ }^{1}$ Apparent consumption calculated as production plus imports minus exports, not adjusted to account for changes in government and industry stocks.

${ }^{2}$ Combined production and exports of Kazakhstan and Russia. 
Table A7. Asbestos production, trade, and consumption in 1975.

[Data in metric tons. Term used: - , zero. Data are unrounded but are believed to be accurate to no more than three significant digits. Production, import, and export data from Great Britain Institute of Geological Sciences, 1981]

\begin{tabular}{|c|c|c|c|c|}
\hline Region and country & Production & Imports & Exports & $\begin{array}{c}\text { Apparent } \\
\text { consumption }{ }^{1}\end{array}$ \\
\hline \multicolumn{5}{|l|}{ Africa: } \\
\hline Algeria.. & - & 4,582 & - & 4,582 \\
\hline Egypt ... & 479 & 5,477 & - & 5,956 \\
\hline Ghana.... & - & 13,188 & - & 13,188 \\
\hline Kenya .... & - & 743 & - & 743 \\
\hline Libya ....... & - & 1,335 & - & 1,335 \\
\hline Morocco .... & - & 7,160 & - & 7,160 \\
\hline Mozambique . & - & 740 & 1,148 & -408 \\
\hline Nigeria........... & - & 29,024 & - & 29,024 \\
\hline Senegal... & - & 1,132 & - & 1,132 \\
\hline 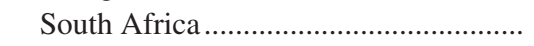 & 354,710 & 28,560 & 368,000 & 15,270 \\
\hline Southern Rhodesia.. & 261,542 & - & 260,000 & 1,542 \\
\hline 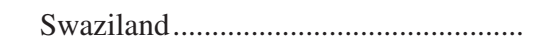 & 37,601 & - & 41,219 & $-3,618$ \\
\hline 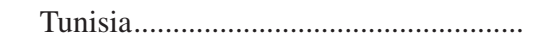 & - & 1,619 & - & 1,619 \\
\hline 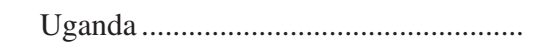 & - & 28 & - & 28 \\
\hline Zaire $^{2}$ & - & 672 & - & 672 \\
\hline 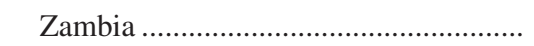 & - & 2,765 & - & 2,765 \\
\hline Total ....... & 654,332 & 97,025 & 670,367 & 80,990 \\
\hline \multicolumn{5}{|l|}{ Asia and the Middle East: } \\
\hline 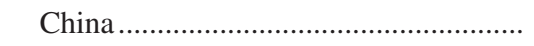 & 150,000 & - & - & 150,000 \\
\hline 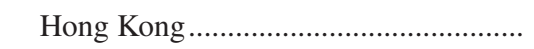 & - & 907 & 705 & 202 \\
\hline 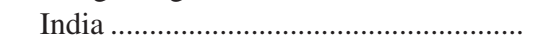 & 20,312 & 41,514 & - & 61,826 \\
\hline Indonesia ......................... & - & 4,845 & - & 4,845 \\
\hline 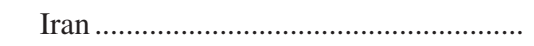 & - & 24,814 & - & 24,814 \\
\hline Iraq & - & 1,482 & - & 1,482 \\
\hline 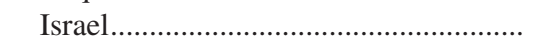 & - & 856 & - & 856 \\
\hline 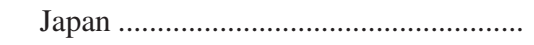 & 4,612 & 253,097 & 2,158 & 255,551 \\
\hline 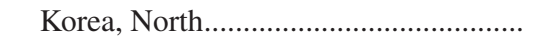 & - & 3,300 & - & 3,300 \\
\hline 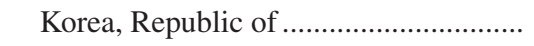 & 4,345 & 56,960 & - & 61,305 \\
\hline 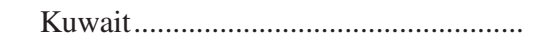 & - & 5,666 & - & 5,666 \\
\hline 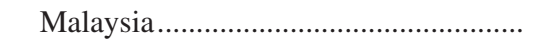 & - & 19,932 & - & 19,932 \\
\hline Pakistan ......... & - & 7,000 & - & 7,000 \\
\hline Philippines... & - & 1,899 & - & 1,899 \\
\hline Saudi Arabia... & - & 10,405 & - & 10,405 \\
\hline Singapore ............ & - & 10,341 & 1,670 & 8,671 \\
\hline Sri Lanka........ & - & 789 & - & 789 \\
\hline Syria .................... & - & 3,391 & - & 3,391 \\
\hline 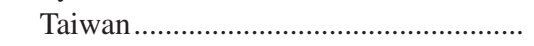 & 1,737 & 13,363 & - & 15,100 \\
\hline 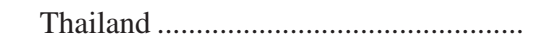 & - & 42,521 & - & 42,521 \\
\hline 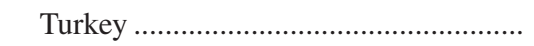 & 15,496 & 16,357 & - & 31,853 \\
\hline United Arab Emirates ............................... & - & 2,000 & - & 2,000 \\
\hline Total & 196,502 & 521,439 & 4,533 & 713,408 \\
\hline \multicolumn{5}{|l|}{ Central and North America: } \\
\hline 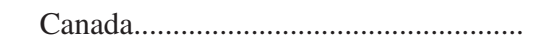 & $1,055,667$ & 5,166 & $1,085,610$ & $-24,777$ \\
\hline 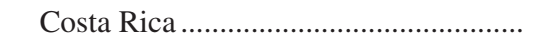 & - & 2,974 & - & 2,974 \\
\hline 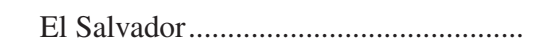 & - & 3,866 & - & 3,866 \\
\hline 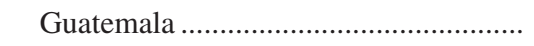 & - & 1,808 & - & 1,808 \\
\hline 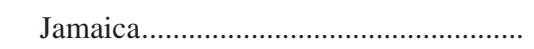 & - & 1,307 & - & 1,307 \\
\hline
\end{tabular}




\section{Worldwide Asbestos Supply and Consumption Trends from 1900 through 2003}

Table A7. Asbestos production, trade, and consumption in 1975.-Continued

[Data in metric tons. Term used: - , zero. Data are unrounded but are believed to be accurate to no more than three significant digits. Production, import, and export data from Great Britain Institute of Geological Sciences, 1981]

\begin{tabular}{|c|c|c|c|c|}
\hline Region and country & Production & Imports & Exports & $\begin{array}{c}\text { Apparent } \\
\text { consumption }{ }^{1} \\
\end{array}$ \\
\hline \multicolumn{5}{|l|}{ Central and North America (continued): } \\
\hline Mexico ............. & - & 60,395 & - & 60,395 \\
\hline 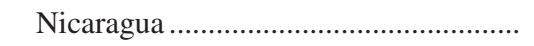 & - & 1,207 & - & 1,207 \\
\hline 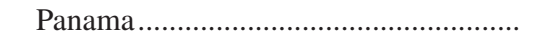 & - & 83 & - & 83 \\
\hline 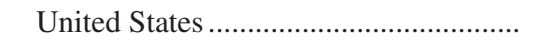 & 89,497 & 488,567 & 33,064 & 545,000 \\
\hline Total …......................................... & $1,145,164$ & 565,373 & $1,118,674$ & 591,863 \\
\hline \multicolumn{5}{|l|}{ Europe: } \\
\hline Austria..... & - & 34,343 & 183 & 34,160 \\
\hline Belgium and Luxembourg ..................... & - & 60,549 & 1,721 & 58,828 \\
\hline 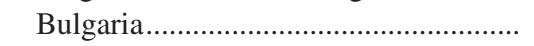 & - & 28,812 & - & 28,812 \\
\hline Canary Islands.. & - & 288 & - & 288 \\
\hline Cyprus .................. & 31,602 & - & 28,378 & 3,224 \\
\hline Czechoslovakia .. & - & 43,494 & - & 43,494 \\
\hline Denmark.. & - & 24,388 & 112 & 24,276 \\
\hline Finland ...... & 2,791 & 10,132 & 3,512 & 9,411 \\
\hline France..... & - & 138,637 & 2,050 & 136,587 \\
\hline Germany, East ........ & - & 65,725 & - & 65,725 \\
\hline Germany, West ......... & - & 386,188 & 73,770 & 312,418 \\
\hline 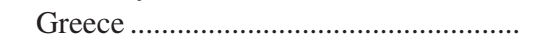 & - & 13,306 & - & 13,306 \\
\hline 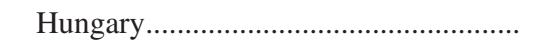 & - & 32,604 & - & 32,604 \\
\hline Iceland........................... & - & 7 & - & 7 \\
\hline 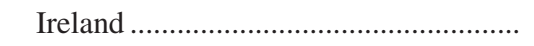 & - & 6,848 & - & 6,848 \\
\hline Italy & 146,984 & 66,273 & 81,073 & 132,184 \\
\hline 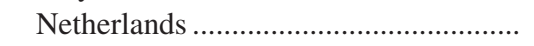 & - & 35,852 & 189 & 35,663 \\
\hline 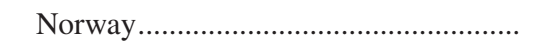 & - & 5,629 & - & 5,629 \\
\hline 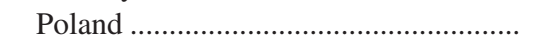 & - & 94,412 & - & 94,412 \\
\hline Portugal ....................... & - & 5,778 & - & 5,778 \\
\hline 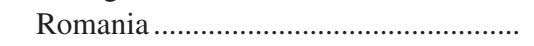 & - & 41,299 & - & 41,299 \\
\hline 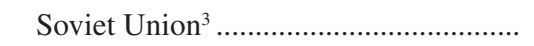 & $1,900,000$ & - & 613,303 & $1,286,697$ \\
\hline Spain & - & 94,114 & - & 94,114 \\
\hline 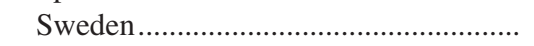 & - & 15,529 & 173 & 15,356 \\
\hline 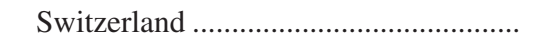 & - & 17,262 & 82 & 17,180 \\
\hline United Kingdom.......... & - & 139,185 & 1,698 & 137,487 \\
\hline 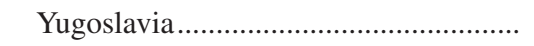 & 12,336 & 52,138 & 3,170 & 61,304 \\
\hline Total .................. & $2,093,713$ & $1,412,792$ & 809,414 & $2,697,091$ \\
\hline \multicolumn{5}{|l|}{ Oceania: } \\
\hline Australia .............. & 47,922 & 49,794 & 24,524 & 73,192 \\
\hline New Zealand ........ & - & 12,484 & - & 12,484 \\
\hline 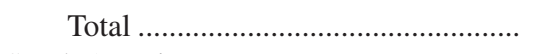 & 47,922 & 62,278 & 24,524 & 85,676 \\
\hline \multicolumn{5}{|l|}{ South America: } \\
\hline Argentina......... & 1,130 & 15,548 & - & 16,678 \\
\hline Bolivia .............. & - & 750 & - & 750 \\
\hline Brazil ................... & 73,978 & 29,800 & - & 103,778 \\
\hline 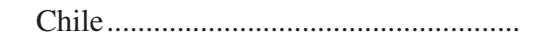 & - & 2,000 & - & 2,000 \\
\hline 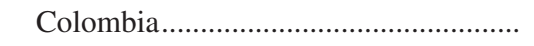 & - & 15,000 & - & 15,000 \\
\hline 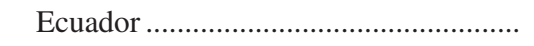 & - & 3,000 & - & 3,000 \\
\hline 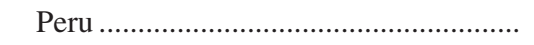 & - & 3,500 & - & 3,500 \\
\hline
\end{tabular}


Table A7. Asbestos production, trade, and consumption in 1975.-Continued

[Data in metric tons. Term used: —, zero. Data are unrounded but are believed to be accurate to no more than three significant digits. Production, import, and export data from Great Britain Institute of Geological Sciences, 1981]

\begin{tabular}{|c|c|c|c|c|}
\hline Region and country & Production & Imports & Exports & $\begin{array}{c}\text { Apparent } \\
\text { consumption }{ }^{1} \\
\end{array}$ \\
\hline \multicolumn{5}{|l|}{ South America (continued): } \\
\hline Uruguay... & - & 1,927 & - & 1,927 \\
\hline Venezuela & 一 & 15,548 & - & 15,548 \\
\hline Total ... & 75,108 & 87,073 & - & 162,181 \\
\hline 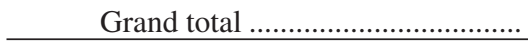 & $4,212,741$ & $2,745,980$ & $2,627,512$ & $4,331,209$ \\
\hline
\end{tabular}

${ }^{1}$ Apparent consumption calculated as production plus imports minus exports, not adjusted to account for changes in government and industry stocks. Negative values indicate shipments from stocks.

${ }^{2}$ Belgian Congo became Zaire between 1960 and 1998 and the Democratic Republic of the Congo [or Congo (Kinshasa)] after 1998.

${ }^{3}$ Combined production and exports of Kazakhstan and Russia. 
Table A8. Asbestos production, trade, and consumption in 1980.

[Data in metric tons. Term used: —, zero. Data are unrounded but are believed to be accurate to no more than three significant digits. Production, import, and export data from British Geological Survey, 1984]

\begin{tabular}{|c|c|c|c|c|}
\hline Region and country & Production & Imports & Exports & $\begin{array}{c}\text { Apparent } \\
\text { consumption }{ }^{1}\end{array}$ \\
\hline \multicolumn{5}{|l|}{ Africa: } \\
\hline Algeria... & - & 21,305 & - & 21,305 \\
\hline Burundi ... & - & 125 & - & 125 \\
\hline Egypt ........ & 316 & 4,387 & - & 4,703 \\
\hline Kenya ..... & - & 1,403 & - & 1,403 \\
\hline Libya ......... & - & 307 & - & 307 \\
\hline 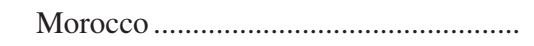 & - & 6,770 & - & 6,770 \\
\hline 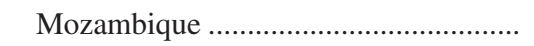 & 800 & 1,082 & - & 1,882 \\
\hline 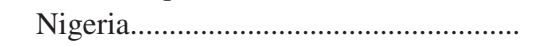 & - & 22,000 & - & 22,000 \\
\hline 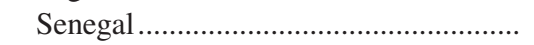 & - & 1,177 & - & 1,177 \\
\hline 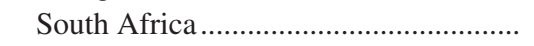 & 277,734 & 19,518 & 381,000 & $-83,748$ \\
\hline 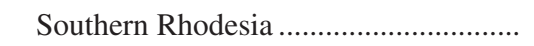 & 250,949 & - & 274,258 & $-23,309$ \\
\hline 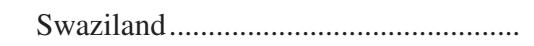 & 32,833 & - & 31,435 & 1,398 \\
\hline 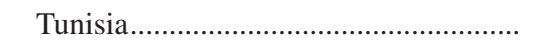 & - & 5,838 & - & 5,838 \\
\hline 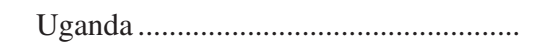 & - & 132 & - & 132 \\
\hline Zaire & - & 118 & - & 118 \\
\hline Total ...... & 562,632 & 84,162 & 686,693 & $-39,899$ \\
\hline \multicolumn{5}{|l|}{ Asia and the Middle East: } \\
\hline Burma................................ & - & 1,825 & - & 1,825 \\
\hline China & 250,000 & - & 9,000 & 241,000 \\
\hline 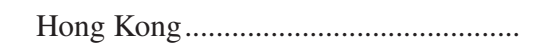 & - & 8,776 & 8,492 & 284 \\
\hline India & 33,716 & 63,176 & - & 96,892 \\
\hline 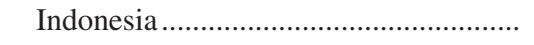 & - & 23,047 & - & 23,047 \\
\hline Iran & - & 23,392 & - & 23,392 \\
\hline 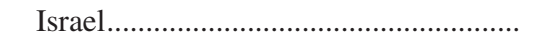 & - & 3,050 & - & 3,050 \\
\hline 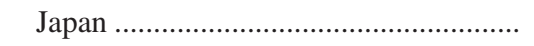 & 3,897 & 395,408 & 428 & 398,877 \\
\hline Korea, Republic of ................................. & 9,854 & 36,787 & - & 46,641 \\
\hline Kuwait ............................ & - & 2,084 & - & 2,084 \\
\hline Malaysia... & - & 32,242 & - & 32,242 \\
\hline Pakistan ............... & - & 10,679 & - & 10,679 \\
\hline Philippines..... & - & 4,467 & - & 4,467 \\
\hline Saudi Arabia.... & - & 52,225 & - & 52,225 \\
\hline Singapore ................ & - & 16,661 & 10,461 & 6,200 \\
\hline 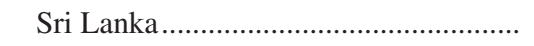 & - & 6,188 & - & 6,188 \\
\hline 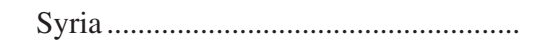 & - & 4,076 & - & 4,076 \\
\hline 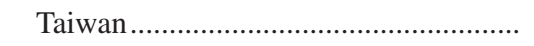 & 683 & 31,247 & - & 31,930 \\
\hline 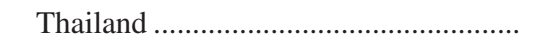 & - & 58,756 & - & 58,756 \\
\hline 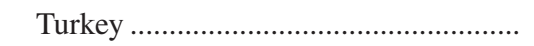 & 8,882 & 16,671 & - & 25,553 \\
\hline United Arab Emirates ............................... & - & 4,631 & - & 4,631 \\
\hline 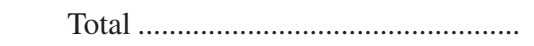 & 307,032 & 795,388 & 28,381 & $1,074,039$ \\
\hline \multicolumn{5}{|l|}{ Central and North America: } \\
\hline 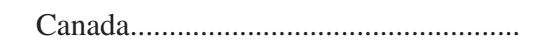 & $1,323,053$ & 1,156 & $1,217,840$ & 106,369 \\
\hline 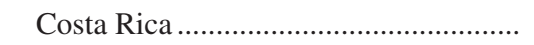 & - & 1,318 & - & 1,318 \\
\hline 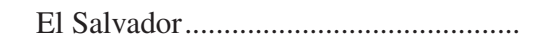 & - & 3,324 & - & 3,324 \\
\hline 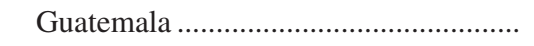 & - & 1,825 & - & 1,825 \\
\hline 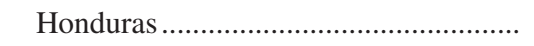 & - & 2,102 & - & 2,102 \\
\hline
\end{tabular}


Table A8. Asbestos production, trade, and consumption in 1980.-Continued

[Data in metric tons. Term used: - , zero. Data are unrounded but are believed to be accurate to no more than three significant digits. Production, import, and export data from British Geological Survey, 1984]

\begin{tabular}{|c|c|c|c|c|}
\hline Region and country & Production & Imports & Exports & $\begin{array}{c}\text { Apparent } \\
\text { consumption }{ }^{1}\end{array}$ \\
\hline \multicolumn{5}{|l|}{ Central and North America (continued): } \\
\hline Jamaica..... & - & 4 & - & 4 \\
\hline 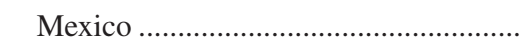 & - & 79,014 & - & 79,014 \\
\hline Nicaragua... & - & 848 & - & 848 \\
\hline Panama........ & - & 283 & - & 283 \\
\hline 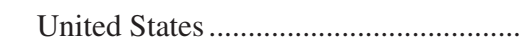 & 80,079 & 327,295 & 48,666 & 358,708 \\
\hline Total & $1,403,132$ & 417,169 & $1,266,506$ & 553,795 \\
\hline \multicolumn{5}{|l|}{ Europe: } \\
\hline 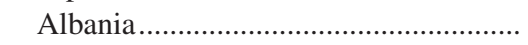 & - & 2,400 & - & 2,400 \\
\hline 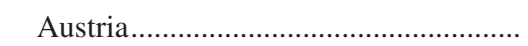 & - & 20,241 & - & 20,241 \\
\hline Belgium and Luxembourg ...................... & - & 47,880 & 57 & 47,823 \\
\hline 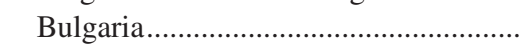 & 650 & 500 & - & 1,150 \\
\hline 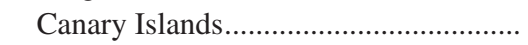 & - & 131 & - & 131 \\
\hline 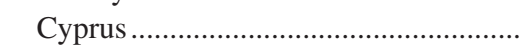 & 35,535 & - & 30,446 & 5,089 \\
\hline Czechoslovakia ........ & 617 & 46,197 & - & 46,814 \\
\hline 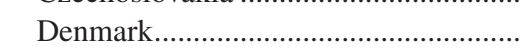 & - & 13,713 & 48 & 13,665 \\
\hline Finland ........................ & - & 5,040 & - & 5,040 \\
\hline France & - & 127,123 & 1,574 & 125,549 \\
\hline 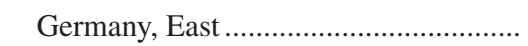 & - & 74,400 & - & 74,400 \\
\hline 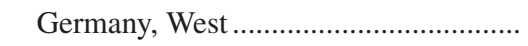 & - & 392,978 & 27,333 & 365,645 \\
\hline 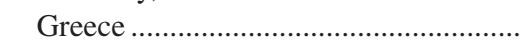 & - & 14,180 & - & 14,180 \\
\hline 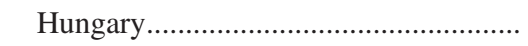 & - & 48,402 & 5,300 & 43,102 \\
\hline Iceland................................ & - & 5 & - & 5 \\
\hline Ireland .................... & - & 8,413 & - & 8,413 \\
\hline Italy ....................... & 157,794 & 86,550 & 63,815 & 180,529 \\
\hline Netherlands ............ & - & 19,042 & 36 & 19,006 \\
\hline Norway................. & - & 103 & - & 103 \\
\hline Poland . & - & 83,272 & - & 83,272 \\
\hline Portugal... & - & 19,953 & - & 19,953 \\
\hline Romania ........... & - & 4,900 & - & 4,900 \\
\hline Soviet Union ${ }^{2}$............. & $2,070,000$ & - & 600,000 & $1,470,000$ \\
\hline Spain & - & 66,944 & - & 66,944 \\
\hline 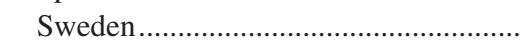 & - & 1,195 & 14 & 1,181 \\
\hline 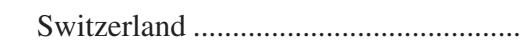 & - & 21,029 & 43 & 20,986 \\
\hline 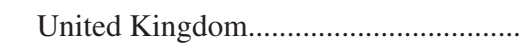 & - & 94,640 & 1,114 & 93,526 \\
\hline 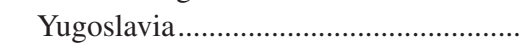 & 10,468 & 60,023 & 2,506 & 67,985 \\
\hline 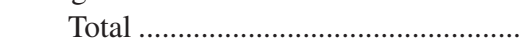 & $2,275,064$ & $1,259,254$ & 732,286 & $2,802,032$ \\
\hline \multicolumn{5}{|l|}{ Oceania: } \\
\hline Australia ...................... & 92,418 & 25,239 & 51,172 & 66,485 \\
\hline 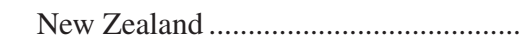 & - & 4,952 & - & 4,952 \\
\hline Total & 92,418 & 30,191 & 51,172 & 71,437 \\
\hline \multicolumn{5}{|l|}{ South America: } \\
\hline Argentina.................. & 1,261 & 20,149 & - & 21,410 \\
\hline 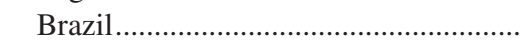 & 170,403 & 24,799 & - & 195,202 \\
\hline 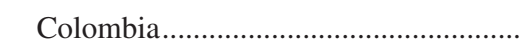 & - & 27,057 & - & 27,057 \\
\hline 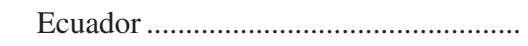 & - & 7,138 & - & 7,138 \\
\hline
\end{tabular}


Table A8. Asbestos production, trade, and consumption in 1980.-Continued

[Data in metric tons. Term used: - , zero. Data are unrounded but are believed to be accurate to no more than three significant digits. Production, import, and export data from British Geological Survey, 1984]

\begin{tabular}{|c|c|c|c|c|}
\hline Region and country & Production & Imports & Exports & $\begin{array}{c}\text { Apparent } \\
\text { consumption }\end{array}$ \\
\hline \multicolumn{5}{|l|}{ South America (continued): } \\
\hline Peru & - & 4,870 & - & 4,870 \\
\hline 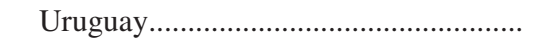 & - & 2,427 & - & 2,427 \\
\hline 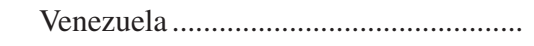 & - & 9,111 & - & 9,111 \\
\hline Total & 171,664 & 95,551 & - & 267,215 \\
\hline Grand total .................................... & $4,811,942$ & $2,681,715$ & $2,765,038$ & $4,728,619$ \\
\hline
\end{tabular}

${ }^{1}$ Apparent consumption calculated as production plus imports minus exports, not adjusted to account for changes in government and industry stocks. Negative values indicate shipments from stocks.

${ }^{2}$ Combined production and exports of Kazakhstan and Russia. 
Table A9. Asbestos production, trade, and consumption in 1985.

[Data in metric tons. Term used: - , zero. Data are unrounded but are believed to be accurate to no more than three significant digits. Production, import, and export data from British Geological Survey, 1991]

\begin{tabular}{|c|c|c|c|c|}
\hline Region and country & Production & Imports & Exports & $\begin{array}{c}\text { Apparent } \\
\text { consumption }{ }^{1}\end{array}$ \\
\hline \multicolumn{5}{|l|}{ Africa: } \\
\hline Algeria.. & - & 31,752 & - & 31,752 \\
\hline Burundi . & - & 422 & - & 422 \\
\hline Egypt..... & 229 & 13,090 & - & 13,319 \\
\hline Ghana.. & - & 1,760 & - & 1,760 \\
\hline Kenya .... & - & 766 & - & 766 \\
\hline Morocco.. & - & 1,110 & - & 1,110 \\
\hline Mozambique .............. & 55 & 3 & - & 58 \\
\hline 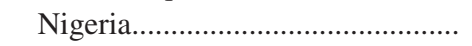 & - & 10,778 & - & 10,778 \\
\hline 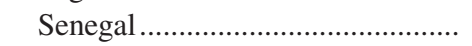 & - & 708 & - & 708 \\
\hline 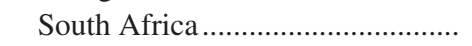 & 194,905 & 11,528 & 175,929 & 30,504 \\
\hline 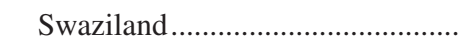 & 25,130 & - & 24,791 & 339 \\
\hline 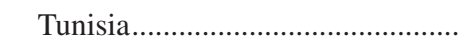 & - & 5,852 & - & 5,852 \\
\hline 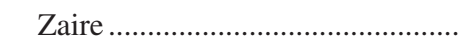 & - & 200 & - & 200 \\
\hline 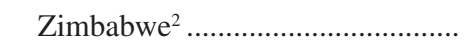 & 173,500 & - & 158,633 & 14,867 \\
\hline 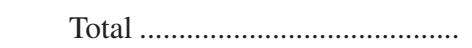 & 393,819 & 77,969 & 359,353 & 112,435 \\
\hline \multicolumn{5}{|l|}{ Asia and the Middle East: } \\
\hline 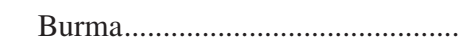 & - & 1,348 & - & 1,348 \\
\hline China.... & 150,000 & 1,700 & 1,700 & 150,000 \\
\hline India ........... & 29,450 & 78,075 & - & 107,525 \\
\hline Indonesia ......... & 25,000 & 8,149 & - & 33,149 \\
\hline Iran & - & 20,451 & - & 20,451 \\
\hline Israel... & - & 3,621 & - & 3,621 \\
\hline 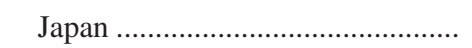 & 2,971 & 261,648 & 292 & 264,327 \\
\hline 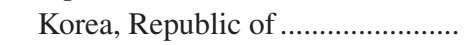 & 4,703 & 57,143 & - & 61,846 \\
\hline 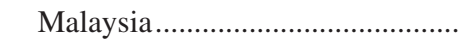 & - & 19,064 & - & 19,064 \\
\hline 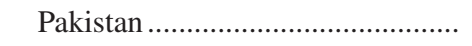 & - & 2,028 & - & 2,028 \\
\hline 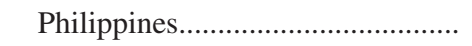 & - & 1,190 & - & 1,190 \\
\hline 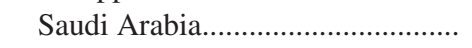 & - & 4,547 & 985 & 3,562 \\
\hline 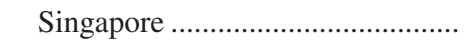 & - & 6,078 & 7,117 & $-1,039$ \\
\hline 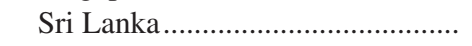 & - & 8,590 & - & 8,590 \\
\hline 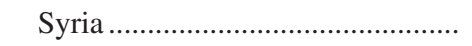 & - & 5,928 & - & 5,928 \\
\hline Taiwan... & 625 & 24,519 & - & 25,144 \\
\hline Thailand.. & - & 71,516 & - & 71,516 \\
\hline Turkey ............... & 29,039 & 25,544 & - & 54,583 \\
\hline United Arab Emirates ......... & - & 6,624 & - & 6,624 \\
\hline Total ... & 241,788 & 607,763 & 10,094 & 839,457 \\
\hline \multicolumn{5}{|l|}{ Central and North America: } \\
\hline Canada... & 750,190 & 374 & 721,560 & 29,004 \\
\hline Cuba ........... & - & 1,658 & - & 1,658 \\
\hline Dominican Republic ........................... & - & 641 & - & 641 \\
\hline 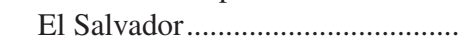 & - & 1,769 & - & 1,769 \\
\hline 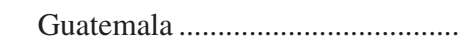 & - & 1,101 & - & 1,101 \\
\hline 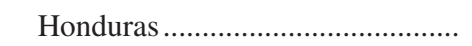 & - & 1,902 & - & 1,902 \\
\hline 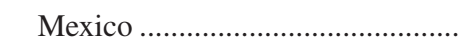 & - & 54,868 & - & 54,868 \\
\hline 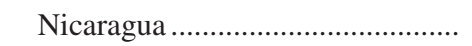 & - & 3,676 & - & 3,676 \\
\hline 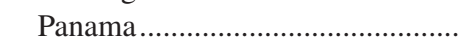 & - & 225 & - & 225 \\
\hline 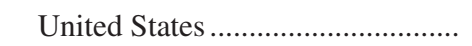 & 57,457 & 142,429 & 45,656 & 154,230 \\
\hline Total .................. & 807,647 & 208,643 & 767,216 & 249,074 \\
\hline
\end{tabular}


Table A9. Asbestos production, trade, and consumption in 1985.-Continued

[Data in metric tons. Term used: - , zero. Data are unrounded but are believed to be accurate to no more than three significant digits. Production, import, and export data from British Geological Survey, 1991]

\begin{tabular}{|c|c|c|c|c|}
\hline Region and country & Production & Imports & Exports & $\begin{array}{c}\text { Apparent } \\
\text { consumption }{ }^{1}\end{array}$ \\
\hline \multicolumn{5}{|l|}{ Europe: } \\
\hline Albania.. & - & 1,500 & - & 1,500 \\
\hline 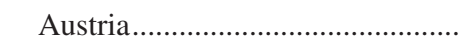 & - & 21,595 & - & 21,595 \\
\hline Belgium and Luxembourg ............ & - & 25,138 & 254 & 24,884 \\
\hline 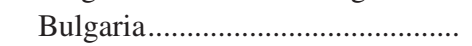 & 400 & 35,472 & - & 35,872 \\
\hline Cyprus ..... & 16,360 & 462 & 16,948 & -126 \\
\hline 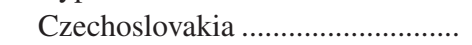 & - & 46,783 & - & 46,783 \\
\hline 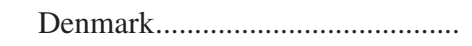 & - & 10,362 & - & 10,362 \\
\hline Finland & - & 2,479 & - & 2,479 \\
\hline 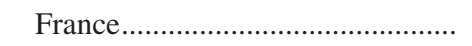 & - & 63,873 & 979 & 62,894 \\
\hline 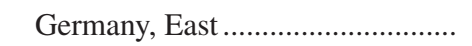 & - & 54,600 & - & 54,600 \\
\hline 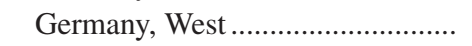 & - & 63,172 & 3,064 & 60,108 \\
\hline 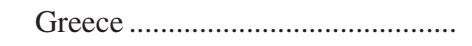 & 46,811 & 4,653 & 29,387 & 22,077 \\
\hline Hungary..... & - & 33,596 & - & 33,596 \\
\hline Ireland . & - & 5,243 & - & 5,243 \\
\hline Italy ....... & 136,006 & 47,952 & 66,244 & 117,714 \\
\hline Netherlands . & - & 5,625 & 50 & 5,575 \\
\hline Poland ... & - & 81,690 & - & 81,690 \\
\hline Portugal. & - & 9,932 & - & 9,932 \\
\hline Romania.. & - & 4,700 & - & 4,700 \\
\hline Soviet Union ${ }^{3}$. & $2,500,000$ & - & 309,800 & $2,190,200$ \\
\hline 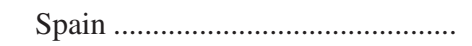 & - & 38,022 & 189 & 37,833 \\
\hline Sweden.... & - & 1,042 & - & 1,042 \\
\hline 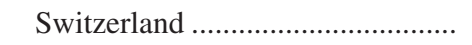 & - & 5,058 & - & 5,058 \\
\hline United Kingdom.... & - & 37,639 & 308 & 37,331 \\
\hline 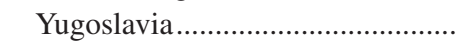 & 6,918 & 54,373 & 2,018 & 59,273 \\
\hline 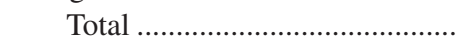 & $2,706,495$ & 654,961 & 429,241 & $2,932,215$ \\
\hline \multicolumn{5}{|l|}{ Oceania: } \\
\hline Australia.. & - & 12,194 & - & 12,194 \\
\hline New Zealand ... & - & 1,304 & - & 1,304 \\
\hline Total ................. & - & 13,498 & - & 13,498 \\
\hline \multicolumn{5}{|l|}{ South America: } \\
\hline Argentina....... & 1,244 & 5,864 & - & 7,108 \\
\hline Brazil............... & 165,446 & 2,591 & 23,248 & 144,789 \\
\hline Chile.......... & - & 8,387 & - & 8,387 \\
\hline 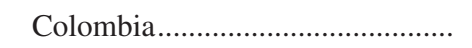 & 12,435 & 14,185 & - & 26,620 \\
\hline 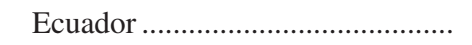 & - & 5,031 & - & 5,031 \\
\hline Peru & - & 3,242 & - & 3,242 \\
\hline 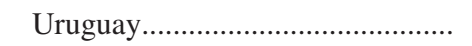 & - & 596 & - & 596 \\
\hline 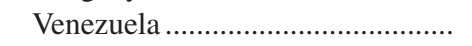 & - & 4,669 & - & 4,669 \\
\hline 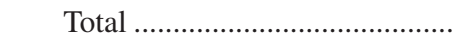 & 179,125 & 44,565 & 23,248 & 200,442 \\
\hline Grand total ........................... & $4,328,874$ & $1,607,399$ & $1,589,152$ & $4,347,121$ \\
\hline
\end{tabular}

${ }^{1}$ Apparent consumption calculated as production plus imports minus exports, not adjusted to account for changes in government and industry stocks. Negative values indicate shipments from stocks.

${ }^{2}$ Southern Rhodesia became Zimbabwe after 1980.

${ }^{3}$ Combined production and exports of Kazakhstan and Russia. 
Table A10. Asbestos production, trade, and consumption in 1990.

[Data in metric tons. Term used: - , zero. Data are unrounded but are believed to be accurate to no more than three significant digits. Production, import, and export data from British Geological Survey, 1995]

\begin{tabular}{|c|c|c|c|c|}
\hline Region and country & Production & Imports & Exports & $\begin{array}{c}\begin{array}{c}\text { Apparent } \\
\text { consumption }\end{array} \\
\end{array}$ \\
\hline \multicolumn{5}{|l|}{ Africa: } \\
\hline Algeria..... & - & 17,382 & - & 17,382 \\
\hline Burundi ... & - & 68 & - & 68 \\
\hline Egypt ...................... & 367 & - & - & 367 \\
\hline 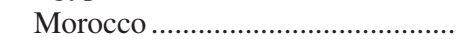 & - & 7,157 & - & 7,157 \\
\hline 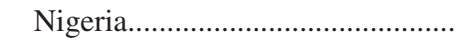 & - & 10,000 & - & 10,000 \\
\hline Senegal... & - & 646 & - & 646 \\
\hline South Africa & 161,494 & 12,354 & 178,750 & $-4,902$ \\
\hline 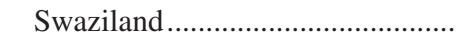 & 35,938 & - & 19,292 & 16,646 \\
\hline 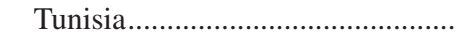 & - & 7,179 & - & 7,179 \\
\hline Zambia & - & 2,472 & - & 2,472 \\
\hline Zimbabwe ....... & 160,500 & - & 172,206 & $-11,706$ \\
\hline$\ldots \ldots \ldots \ldots \ldots \ldots \ldots \ldots \ldots$ & 358,299 & 57,258 & 370,248 & 45,309 \\
\hline \multicolumn{5}{|l|}{ Asia and the Middle East: } \\
\hline China & 191,800 & 1,083 & 7,135 & 185,748 \\
\hline India & 26,053 & 93,165 & 254 & 118,964 \\
\hline Indonesia ... & - & 28,599 & - & 28,599 \\
\hline Iran ................ & 2,800 & 69,446 & - & 72,246 \\
\hline Israel............................... & - & 2,955 & - & 2,955 \\
\hline Japan .............................. & 5,184 & 287,659 & 142 & 292,701 \\
\hline Korea, Republic of ............................. & 1,534 & 74,549 & - & 76,083 \\
\hline 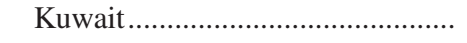 & - & 1,140 & - & 1,140 \\
\hline Malaysia......... & - & 22,000 & - & 22,000 \\
\hline Pakistan & - & 4,525 & - & 4,525 \\
\hline Philippines......................................... & - & 1,869 & - & 1,869 \\
\hline Saudi Arabia........................................ & - & 2,005 & 422 & 1,583 \\
\hline Singapore ......... & - & 4,741 & 2,181 & 2,560 \\
\hline Sri Lanka.... & - & 7,002 & - & 7,002 \\
\hline Syria .... & - & 1,548 & - & 1,548 \\
\hline 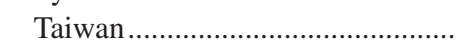 & - & 15,165 & - & 15,165 \\
\hline Thailand & - & 116,652 & - & 116,652 \\
\hline 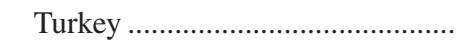 & - & 26,259 & - & 26,259 \\
\hline Total . & 227,371 & 760,362 & 10,134 & 977,599 \\
\hline \multicolumn{5}{|l|}{ Central and North America: } \\
\hline Canada........ & 724,620 & 879 & 649,485 & 76,014 \\
\hline 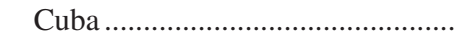 & - & 1,500 & - & 1,500 \\
\hline El Salvador ....................................... & - & 904 & - & 904 \\
\hline 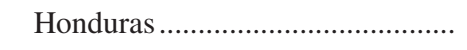 & - & 416 & - & 416 \\
\hline$\ldots$ & - & 39,316 & - & 39,316 \\
\hline$\ldots \ldots \ldots \ldots \ldots . .$. & - & 352 & - & 352 \\
\hline 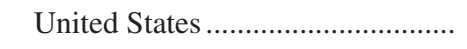 & 20,000 & 41,331 & 28,875 & 32,456 \\
\hline Total & 744,620 & 84,698 & 678,360 & 150,958 \\
\hline \multicolumn{5}{|l|}{ Europe: } \\
\hline Austria & - & 6,167 & 675 & 5,492 \\
\hline Belgium and Luxembourg ............ & - & 26,514 & 310 & 26,204 \\
\hline 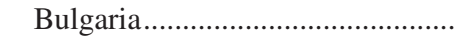 & 500 & - & - & 500 \\
\hline Czechoslovakia ..... & - & 32,776 & - & 32,776 \\
\hline Denmark........ & - & 800 & - & 800 \\
\hline
\end{tabular}


Table A10. Asbestos production, trade, and consumption in 1990.-Continued

[Data in metric tons. Term used: - , zero. Data are unrounded but are believed to be accurate to no more than three significant digits. Production, import, and export data from British Geological Survey, 1995]

\begin{tabular}{|c|c|c|c|c|}
\hline Region and country & Production & Imports & Exports & $\begin{array}{c}\text { Apparent } \\
\text { consumption }\end{array}$ \\
\hline \multicolumn{5}{|l|}{ Europe (continued): } \\
\hline France....................... & - & 63,672 & 101 & 63,571 \\
\hline 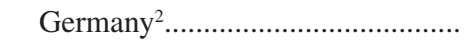 & - & 15,692 & 608 & 15,084 \\
\hline 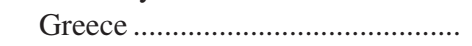 & 65,993 & 2,299 & 56,963 & 11,329 \\
\hline 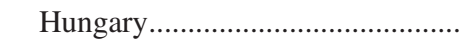 & - & 33,375 & 5,784 & 27,591 \\
\hline Ireland & - & 5,533 & - & 5,533 \\
\hline Italy ......................... & 3,862 & 63,438 & 4,893 & 62,407 \\
\hline Netherlands ........ & - & 6,252 & - & 6,252 \\
\hline Poland ................... & - & 65,621 & - & 65,621 \\
\hline Portugal ................ & - & 12,284 & - & 12,284 \\
\hline Romania ....... & - & 3,000 & - & 3,000 \\
\hline Soviet Union ${ }^{3}$.. & $2,400,000$ & - & 248,200 & $2,151,800$ \\
\hline Spain ..................... & - & 39,609 & 127 & 39,482 \\
\hline Sweden....... & - & 595 & - & 595 \\
\hline Switzerland ...... & - & 1,341 & - & 1,341 \\
\hline 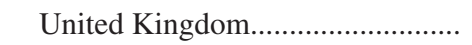 & - & 16,022 & 291 & 15,731 \\
\hline 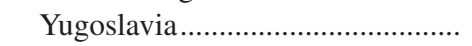 & 6,578 & 28,323 & - & 34,901 \\
\hline 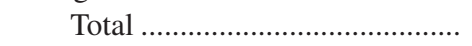 & $2,476,933$ & 423,313 & 317,952 & $2,582,294$ \\
\hline 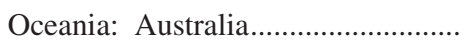 & - & 1,706 & - & 1,706 \\
\hline \multicolumn{5}{|l|}{ South America: } \\
\hline 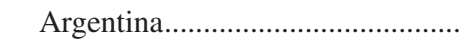 & 275 & 6,588 & - & 6,863 \\
\hline 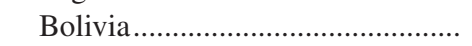 & - & 1,297 & - & 1,297 \\
\hline 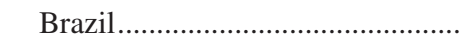 & 205,220 & 11,160 & 53,142 & 163,238 \\
\hline 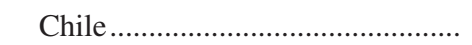 & - & 7,749 & - & 7,749 \\
\hline 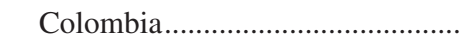 & 8,000 & 13,437 & - & 21,437 \\
\hline 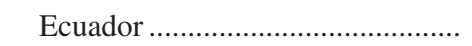 & - & 1,151 & - & 1,151 \\
\hline Peru & - & 1,060 & - & 1,060 \\
\hline 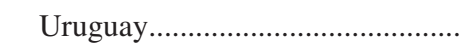 & - & 1,794 & - & 1,794 \\
\hline 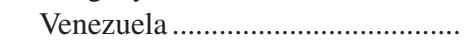 & - & 1,418 & - & 1,418 \\
\hline 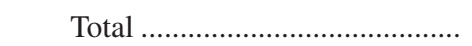 & 213,495 & 45,654 & 53,142 & 206,007 \\
\hline Grand total .............................. & $4,020,718$ & $1,372,991$ & $1,429,836$ & $3,963,873$ \\
\hline
\end{tabular}

${ }^{1}$ Apparent consumption calculated as production plus imports minus exports, not adjusted to account for changes in government and industry stocks. Negative values indicate shipments from stocks.

${ }^{2}$ Germany was divided into East and West Germany from 1949 to 1990.

${ }^{3}$ Combined production and exports of Kazakhstan and Russia. 
Table A11. Asbestos production, trade, and consumption in 1995.

[Data in metric tons. Term used: - , zero. Data are unrounded but are believed to be accurate to no more than three significant digits. Production, import, and export data from British Geological Survey, 2001]

\begin{tabular}{|c|c|c|c|c|}
\hline Region and country & Production & Imports & Exports & $\begin{array}{c}\text { Apparent } \\
\text { consumption }\end{array}$ \\
\hline \multicolumn{5}{|l|}{ Africa: } \\
\hline Algeria.. & - & 10,000 & - & 10,000 \\
\hline Egypt ...... & 392 & 7,600 & - & 7,992 \\
\hline 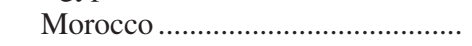 & - & 5,023 & - & 5,023 \\
\hline 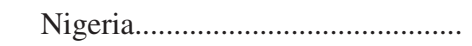 & - & 15,000 & - & 15,000 \\
\hline Senegal..... & - & 300 & - & 300 \\
\hline 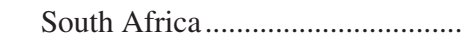 & 88,642 & 7,891 & 92,100 & 4,433 \\
\hline 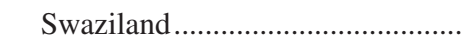 & 28,574 & - & 19,000 & 9,574 \\
\hline 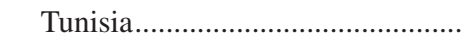 & - & 7,297 & - & 7,297 \\
\hline 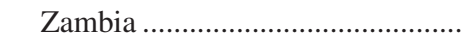 & - & 3,000 & - & 3,000 \\
\hline 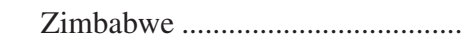 & 169,487 & 1,500 & 174,558 & $-3,571$ \\
\hline Total ...... & 287,095 & 57,611 & 285,658 & 59,048 \\
\hline \multicolumn{5}{|l|}{ Asia and the Middle East: } \\
\hline China.. & 447,000 & 68,300 & 3,465 & 511,835 \\
\hline India ... & 23,844 & 91,909 & 14 & 115,739 \\
\hline Indonesia. & - & 50,231 & - & 50,231 \\
\hline Iran ....... & - & 54,933 & - & 54,933 \\
\hline Israel.... & - & 2,200 & - & 2,200 \\
\hline Japan ........ & 2,399 & 191,475 & 74 & 193,800 \\
\hline 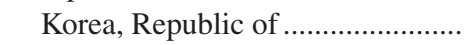 & - & 88,722 & - & 88,722 \\
\hline 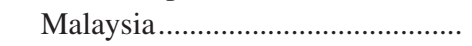 & - & 28,200 & - & 28,200 \\
\hline Oman & - & 181 & - & 181 \\
\hline 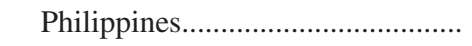 & - & 2,904 & - & 2,904 \\
\hline 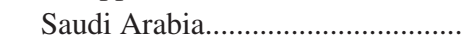 & - & 306 & 8,400 & $-8,094$ \\
\hline 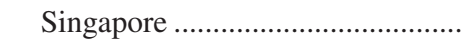 & - & 475 & - & 475 \\
\hline 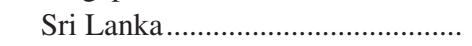 & - & 35 & - & 35 \\
\hline 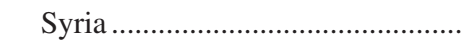 & - & 1,222 & - & 1,222 \\
\hline 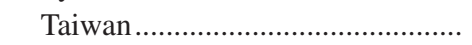 & - & 5,582 & - & 5,582 \\
\hline 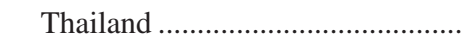 & - & 181,692 & - & 181,692 \\
\hline 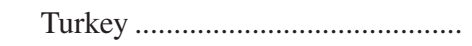 & - & 25,471 & - & 25,471 \\
\hline United Arab Emirates ....................... & - & 6,000 & - & 6,000 \\
\hline Total & 473,243 & 799,838 & 11,953 & $1,261,128$ \\
\hline \multicolumn{5}{|l|}{ Central and North America: } \\
\hline 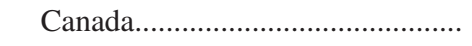 & 524,392 & 297 & 509,575 & 15,114 \\
\hline Cuba & - & 3,000 & - & 3,000 \\
\hline 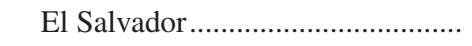 & - & 398 & - & 398 \\
\hline 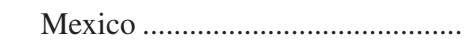 & - & 19,154 & - & 19,154 \\
\hline Panama ............. & - & 844 & - & 844 \\
\hline United States ... & 9,290 & 21,941 & 16,556 & 14,675 \\
\hline 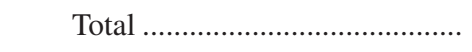 & 533,682 & 45,634 & 526,131 & 53,185 \\
\hline \multicolumn{5}{|l|}{ Europe: } \\
\hline Albania........ & - & 1,000 & - & 1,000 \\
\hline Belarus $^{2}$............ & - & 20,000 & 2,000 & 18,000 \\
\hline Belgium and Luxembourg ............ & - & 10,462 & 94 & 10,368 \\
\hline Bulgaria..... & 100 & - & - & 100 \\
\hline Croatia $^{3} \ldots \ldots \ldots \ldots$ & - & 3,045 & - & 3,045 \\
\hline Czech Republic $^{4} \ldots \ldots \ldots \ldots \ldots \ldots \ldots \ldots$ & - & 4,500 & 100 & 4,400 \\
\hline 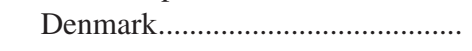 & - & 345 & - & 345 \\
\hline
\end{tabular}


Table A11. Asbestos production, trade, and consumption in 1995.-Continued

[Data in metric tons. Term used: - , zero. Data are unrounded but are believed to be accurate to no more than three significant digits. Production, import, and export data from British Geological Survey, 2001]

\begin{tabular}{|c|c|c|c|c|}
\hline Region and country & Production & Imports & Exports & $\begin{array}{c}\text { Apparent } \\
\text { consumption'1 }\end{array}$ \\
\hline \multicolumn{5}{|l|}{ Europe (continued): } \\
\hline Estonia $^{2}$. & - & 7,976 & 9,037 & $-1,061$ \\
\hline France...................... & - & 48,205 & 224 & 47,981 \\
\hline 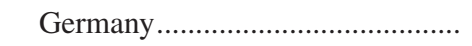 & - & 98 & - & 98 \\
\hline 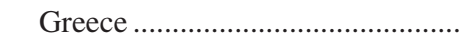 & 75,003 & 272 & 67,991 & 7,284 \\
\hline 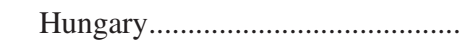 & - & 3,356 & - & 3,356 \\
\hline 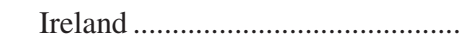 & - & 6,355 & - & 6,355 \\
\hline Italy & - & 126 & 22 & 104 \\
\hline 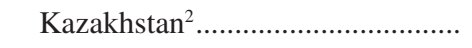 & 160,829 & - & 115,400 & 45,429 \\
\hline Kyrgyzstan $^{2} \ldots \ldots$ & - & 11,445 & 793 & 10,652 \\
\hline Latvia $^{2} \ldots \ldots \ldots \ldots \ldots$ & - & 2,228 & - & 2,228 \\
\hline Lithuania $^{2}$. & - & 5,600 & 5,173 & 427 \\
\hline Macedonia ${ }^{3}$. & - & 2,800 & - & 2,800 \\
\hline Moldova $^{2} \ldots \ldots \ldots \ldots$ & - & 2,800 & - & 2,800 \\
\hline Poland ..................... & - & 31,315 & 948 & 30,367 \\
\hline Portugal.. & - & 9,163 & - & 9,163 \\
\hline Romania ...... & - & 27,425 & - & 27,425 \\
\hline Russia $^{2} \ldots \ldots \ldots$ & 685,000 & 41,400 & 76,820 & 649,580 \\
\hline Serbia $^{3} \ldots \ldots \ldots \ldots \ldots$ & 497 & - & - & 497 \\
\hline Slovakia $^{4} \ldots . .$. & - & 2,300 & 100 & 2,200 \\
\hline Slovenia $^{3}$...................... & - & 4,900 & - & 4,900 \\
\hline Spain .......................... & - & 26,852 & 142 & 26,710 \\
\hline 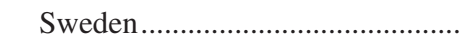 & - & 298 & - & 298 \\
\hline United Kingdom.. & - & 10,157 & 14 & 10,143 \\
\hline Total ..................... & 921,429 & 284,423 & 278,858 & 926,994 \\
\hline Oceania: Australia.. & - & 1,488 & - & 1,488 \\
\hline \multicolumn{5}{|l|}{ South America: } \\
\hline Argentina.... & 300 & 5,788 & - & 6,088 \\
\hline Bolivia.. & - & 1,575 & - & 1,575 \\
\hline Brazil....... & 210,352 & 43,524 & 71,747 & 182,129 \\
\hline Chile.. & - & 11,666 & - & 11,666 \\
\hline Colombia.... & 3,000 & 19,925 & - & 22,925 \\
\hline 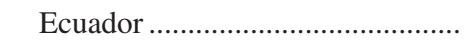 & - & 805 & - & 805 \\
\hline 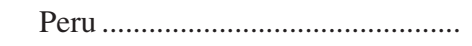 & - & 4,947 & - & 4,947 \\
\hline 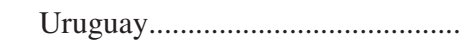 & - & 903 & - & 903 \\
\hline 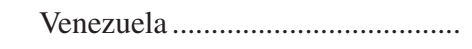 & - & 5,012 & - & 5,012 \\
\hline 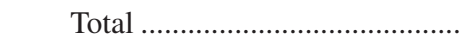 & 213,652 & 94,145 & 71,747 & 236,050 \\
\hline Grand total ........................... & $2,429,101$ & $1,283,139$ & $1,174,347$ & $2,537,893$ \\
\hline
\end{tabular}

${ }^{1}$ Apparent consumption calculated as production plus imports minus exports, not adjusted to account for changes in government and industry stocks. Negative values indicate shipments from stocks.

${ }^{2}$ Data for Belarus, Estonia, Kazakhstan, Kyrgyzstan, Latvia, Lithuania, Moldova, and Russia became available after the dissolution of the Soviet Union in 1991. Both Asian and European countries of the former Soviet Union are listed under Europe to facilitate comparison of regional totals for different time periods.

${ }^{3}$ Data for Croatia, Macedonia, Serbia, and Slovenia were combined under Yugoslavia before 1991.

${ }^{4}$ Data for the Czech Republic and Slovakia were combined under Czechoslovakia before 1993. 
Table A12. Asbestos production, trade, and consumption in 1996.

[Data in metric tons. Term used: —, zero. Data are unrounded but are believed to be accurate to no more than three significant digits. Production, import, and export data from British Geological Survey, 2001]

\begin{tabular}{|c|c|c|c|c|}
\hline Region and country & Production & Imports & Exports & $\begin{array}{c}\text { Apparent } \\
\text { consumption' }\end{array}$ \\
\hline \multicolumn{5}{|l|}{ Africa: } \\
\hline Algeria.. & - & 7,102 & - & 7,102 \\
\hline Egypt .............. & 552 & 29,849 & - & 30,401 \\
\hline 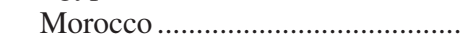 & - & 5,643 & - & 5,643 \\
\hline Nigeria...... & - & 15,841 & - & 15,841 \\
\hline Senegal... & - & 300 & - & 300 \\
\hline South Africa.. & 61,800 & 9,133 & 60,829 & 10,104 \\
\hline Swaziland....... & 26,014 & - & 20,000 & 6,014 \\
\hline Tunisia....... & - & 6,081 & - & 6,081 \\
\hline Zambia . & - & 3,000 & - & 3,000 \\
\hline Zimbabwe. & 165,494 & 1,500 & 152,091 & 14,903 \\
\hline Total & 253,860 & 78,449 & 232,920 & 99,389 \\
\hline \multicolumn{5}{|l|}{ Asia and the Middle East: } \\
\hline China...... & 440,500 & 77,959 & 9,392 & 509,067 \\
\hline Dubai $^{2} \ldots \ldots \ldots \ldots \ldots \ldots$ & - & 6,100 & - & 6,100 \\
\hline 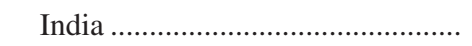 & 27,180 & 84,378 & 275 & 111,283 \\
\hline Indonesia & - & 48,331 & - & 48,331 \\
\hline Iran & 2,127 & - & - & 2,127 \\
\hline 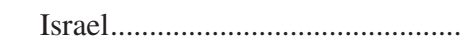 & - & 1,500 & - & 1,500 \\
\hline 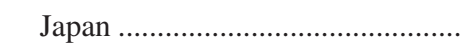 & 2,269 & 177,869 & 133 & 180,005 \\
\hline 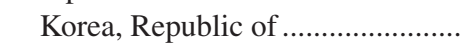 & - & 77,145 & - & 77,145 \\
\hline 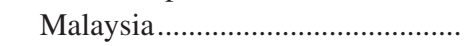 & - & 19,600 & - & 19,600 \\
\hline Oman & - & 2,061 & - & 2,061 \\
\hline Pakistan ... & - & 5,500 & - & 5,500 \\
\hline Philippines.... & - & 1,770 & - & 1,770 \\
\hline 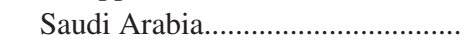 & - & 500 & 11,530 & $-11,030$ \\
\hline 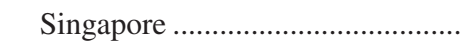 & - & 429 & - & 429 \\
\hline 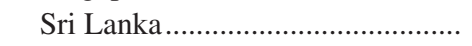 & - & 4,818 & - & 4,818 \\
\hline 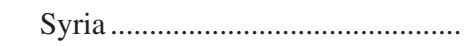 & - & 2,672 & - & 2,672 \\
\hline Taiwan & - & 6,164 & - & 6,164 \\
\hline 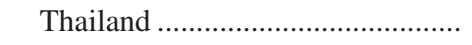 & - & 190,205 & - & 190,205 \\
\hline 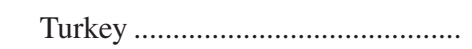 & - & 26,863 & - & 26,863 \\
\hline United Arab Emirates ....................... & - & 6,000 & - & 6,000 \\
\hline Total .. & 472,076 & 739,864 & 21,330 & $1,190,610$ \\
\hline \multicolumn{5}{|l|}{ Central and North America: } \\
\hline 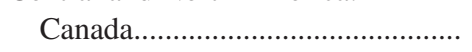 & 475,130 & 353 & 504,069 & $-28,586$ \\
\hline Cuba... & - & 7,100 & - & 7,100 \\
\hline El Salvador... & - & 398 & - & 398 \\
\hline Mexico .............. & - & 29,097 & - & 29,097 \\
\hline 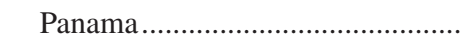 & - & 650 & - & 650 \\
\hline 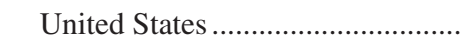 & 9,550 & 30,449 & 24,231 & 15,768 \\
\hline 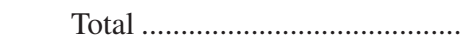 & 484,680 & 68,047 & 528,300 & 24,427 \\
\hline \multicolumn{5}{|l|}{ Europe: } \\
\hline 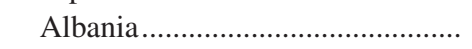 & - & 9 & - & 9 \\
\hline 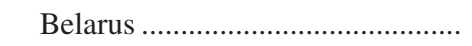 & - & 20,000 & 3,000 & 17,000 \\
\hline Belgium and Luxembourg ............ & - & 5,681 & 11 & 5,670 \\
\hline 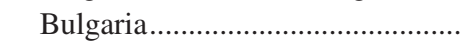 & 400 & - & - & 400 \\
\hline 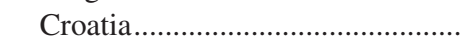 & - & 2,363 & - & 2,363 \\
\hline
\end{tabular}


Table A12. Asbestos production, trade, and consumption in 1996.-Continued

[Data in metric tons. Term used: - , zero. Data are unrounded but are believed to be accurate to no more than three significant digits. Production, import, and export data from British Geological Survey, 2001]

\begin{tabular}{|c|c|c|c|c|}
\hline Region and country & Production & Imports & Exports & $\begin{array}{c}\text { Apparent } \\
\text { consumption }^{1}\end{array}$ \\
\hline \multicolumn{5}{|l|}{ Europe (continued): } \\
\hline 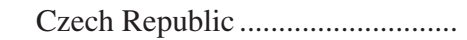 & - & 1,400 & 27,100 & $-25,700$ \\
\hline Denmark................ & - & 225 & - & 225 \\
\hline Estonia........... & - & 800 & 300 & 500 \\
\hline France..................... & - & 20,576 & 14,053 & 6,523 \\
\hline Germany..... & - & 119 & - & 119 \\
\hline Greece .. & 80,213 & 252 & 74,043 & 6,422 \\
\hline Hungary.. & - & 5,249 & - & 5,249 \\
\hline Ireland . & - & 4,638 & - & 4,638 \\
\hline Italy ................. & - & 127 & 51 & 76 \\
\hline Kazakhstan... & 134,484 & - & 139,100 & $-4,616$ \\
\hline Kyrgyzstan ..... & - & 12,542 & - & 12,542 \\
\hline Latvia ................... & - & 1,212 & - & 1,212 \\
\hline 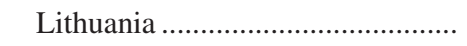 & - & 6,343 & 4,656 & 1,687 \\
\hline 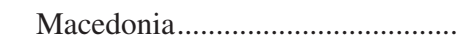 & - & 2,999 & - & 2,999 \\
\hline 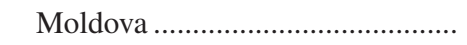 & - & 1,537 & - & 1,537 \\
\hline 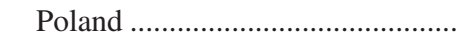 & - & 15,700 & 200 & 15,500 \\
\hline 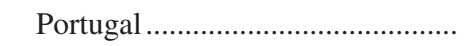 & - & 6,442 & - & 6,442 \\
\hline 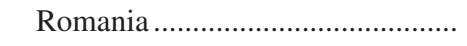 & - & 39,130 & - & 39,130 \\
\hline 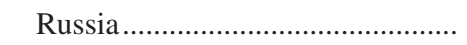 & 629,863 & 31,366 & 33,411 & 627,818 \\
\hline Serbia ........................ & 509 & - & - & 509 \\
\hline Slovakia..................... & 36,000 & 3,322 & 201 & 39,121 \\
\hline Slovenia...................... & - & 5,000 & - & 5,000 \\
\hline Spain ........................... & - & 27,030 & 625 & 26,405 \\
\hline Sweden ................... & - & 158 & - & 158 \\
\hline United Kingdom.... & - & 7,099 & 967 & 6,132 \\
\hline Total ........................ & 881,469 & 221,319 & 297,718 & 805,070 \\
\hline Oceania: Australia... & - & 1,366 & - & 1,366 \\
\hline \multicolumn{5}{|l|}{ South America: } \\
\hline 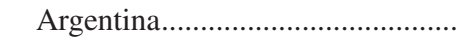 & 446 & 5,791 & - & 6,237 \\
\hline 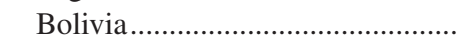 & - & 1,567 & - & 1,567 \\
\hline 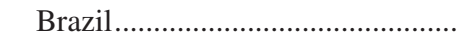 & 213,213 & 31,765 & 78,294 & 166,684 \\
\hline Chile ............. & - & 9,349 & - & 9,349 \\
\hline Colombia........ & 2,000 & 20,548 & - & 22,548 \\
\hline 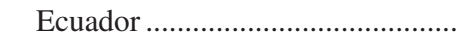 & - & 1,278 & - & 1,278 \\
\hline Peru ................ & - & 4,098 & - & 4,098 \\
\hline 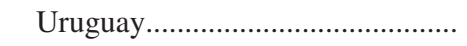 & - & 895 & - & 895 \\
\hline Venezuela ... & 一 & 1,561 & - & 1,561 \\
\hline Total .. & 215,659 & 76,852 & 78,294 & 214,217 \\
\hline Grand total .. & $2,307,744$ & $1,185,897$ & $1,158,562$ & $2,335,079$ \\
\hline
\end{tabular}

${ }^{1}$ Apparent consumption calculated as production plus imports minus exports, not adjusted to account for changes in government and industry stocks. Negative values indicate shipments from stocks.

${ }^{2}$ Although Dubai is one of the seven United Arab Emirates, separate statistical data are available for that state. 
Table A13. Asbestos production, trade, and consumption in 1997.

[Data in metric tons. Term used: —, zero. Data are unrounded but are believed to be accurate to no more than three significant digits. Production, import, and export data from British Geological Survey, 2001]

\begin{tabular}{|c|c|c|c|c|}
\hline Region and country & Production & Imports & Exports & $\begin{array}{c}\text { Apparent } \\
\text { consumption }{ }^{1} \\
\end{array}$ \\
\hline \multicolumn{5}{|l|}{ Africa: } \\
\hline . & - & 9,997 & - & 9,997 \\
\hline 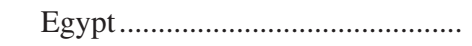 & 776 & 10,100 & - & 10,876 \\
\hline 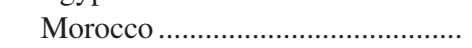 & - & 4,376 & - & 4,376 \\
\hline 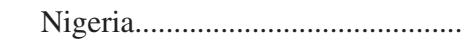 & - & 7,799 & - & 7,799 \\
\hline 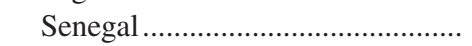 & - & 300 & - & 300 \\
\hline 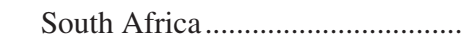 & 49,986 & 9,571 & 38,209 & 21,348 \\
\hline 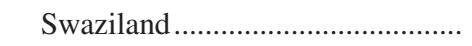 & 25,888 & - & 20,000 & 5,888 \\
\hline 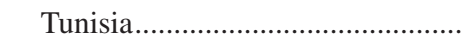 & - & 3,573 & - & 3,573 \\
\hline 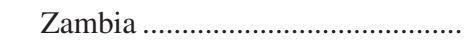 & - & 3,000 & - & 3,000 \\
\hline 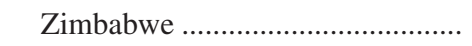 & 144,959 & 1,000 & 143,169 & 2,790 \\
\hline Total ......... & 221,609 & 49,716 & 201,378 & 69,947 \\
\hline \multicolumn{5}{|l|}{ Asia and the Middle East: } \\
\hline China...... & 437,000 & 103,265 & 13,553 & 526,712 \\
\hline Dubai $^{2} \ldots .$. & - & 7,660 & - & 7,660 \\
\hline India ....... & 25,537 & 83,356 & 282 & 108,611 \\
\hline Indonesia ... & - & 41,845 & - & 41,845 \\
\hline Iran ................ & 10,373 & 75,587 & - & 85,960 \\
\hline Japan ............................ & 2,254 & 176,021 & 160 & 178,115 \\
\hline 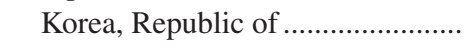 & - & 44,985 & - & 44,985 \\
\hline 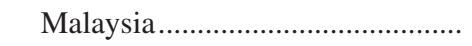 & - & 21,700 & - & 21,700 \\
\hline 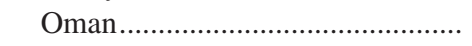 & - & 1,331 & - & 1,331 \\
\hline 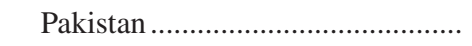 & - & 3,789 & - & 3,789 \\
\hline 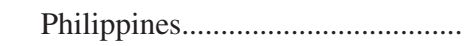 & - & 2,206 & - & 2,206 \\
\hline 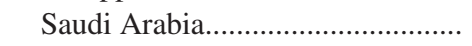 & - & - & 6,440 & $-6,440$ \\
\hline 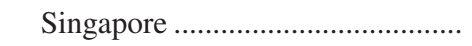 & - & 243 & - & 243 \\
\hline 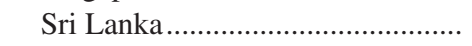 & - & 18 & - & 18 \\
\hline 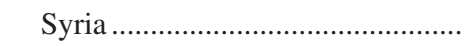 & - & 3,068 & - & 3,068 \\
\hline 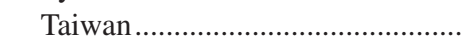 & - & 5,773 & - & 5,773 \\
\hline 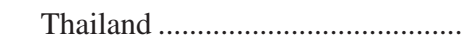 & - & 177,124 & - & 177,124 \\
\hline 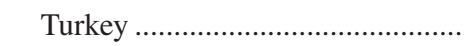 & - & 33,725 & - & 33,725 \\
\hline United Arab Emirates ....................... & - & 6,000 & 一 & 6,000 \\
\hline 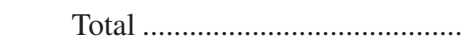 & 475,164 & 787,696 & 20,435 & $1,242,425$ \\
\hline \multicolumn{5}{|l|}{ Central and North America: } \\
\hline 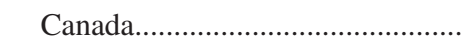 & 454,991 & 128 & 430,288 & 24,831 \\
\hline 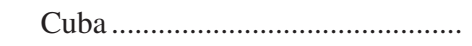 & - & 6,600 & - & 6,600 \\
\hline 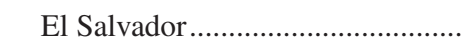 & - & 999 & - & 999 \\
\hline 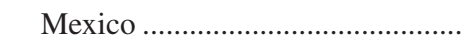 & - & 28,886 & - & 28,886 \\
\hline Panama & - & 1,171 & - & 1,171 \\
\hline 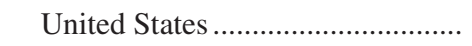 & 6,890 & 20,922 & 23,061 & 4,751 \\
\hline 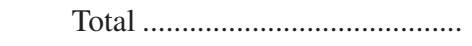 & 461,881 & 58,706 & 453,349 & 67,238 \\
\hline \multicolumn{5}{|l|}{ Europe: } \\
\hline 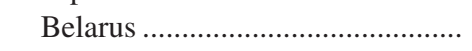 & - & 20,000 & 3,000 & 17,000 \\
\hline Belgium and Luxembourg ............ & - & 2,366 & 263 & 2,103 \\
\hline 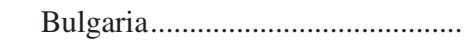 & 300 & - & - & 300 \\
\hline 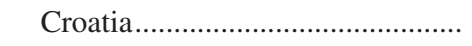 & - & 3,033 & - & 3,033 \\
\hline 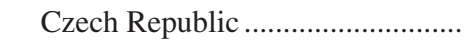 & - & 1,315 & - & 1,315 \\
\hline 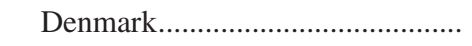 & - & 125 & - & 125 \\
\hline 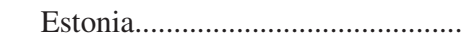 & - & 800 & 4 & 796 \\
\hline
\end{tabular}


Table A13. Asbestos production, trade, and consumption in 1997._-Continued

[Data in metric tons. Term used: - , zero. Data are unrounded but are believed to be accurate to no more than three significant digits. Production, import, and export data from British Geological Survey, 2001]

\begin{tabular}{|c|c|c|c|c|}
\hline Region and country & Production & Imports & Exports & $\begin{array}{c}\text { Apparent } \\
\text { consumption }{ }^{1}\end{array}$ \\
\hline \multicolumn{5}{|l|}{ Europe (continued): } \\
\hline France & - & 55 & 164 & -109 \\
\hline 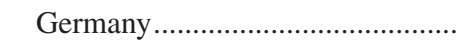 & - & 143 & - & 143 \\
\hline 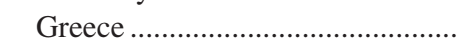 & 63,294 & 239 & 51,720 & 11,813 \\
\hline 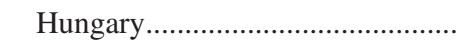 & - & 5,759 & - & 5,759 \\
\hline 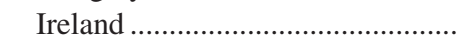 & - & 2,468 & - & 2,468 \\
\hline 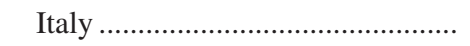 & - & - & 42 & -42 \\
\hline 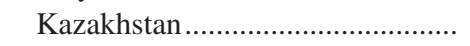 & 181,818 & - & 60,429 & 121,389 \\
\hline Kyrgyzstan ............................... & - & 22,200 & - & 22,200 \\
\hline Latvia .................................... & - & 1,828 & - & 1,828 \\
\hline 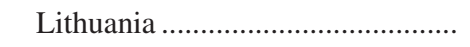 & - & 10,819 & 7,113 & 3,706 \\
\hline Macedonia................................. & - & 1,998 & - & 1,998 \\
\hline Moldova .................................... & - & 3,189 & - & 3,189 \\
\hline Poland ..................... & - & 23,000 & 300 & 22,700 \\
\hline Portugal .................................... & - & 7,324 & - & 7,324 \\
\hline 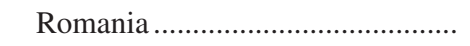 & - & 6,807 & - & 6,807 \\
\hline 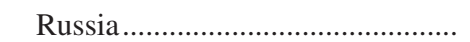 & 723,973 & 17,128 & 98,832 & 642,269 \\
\hline 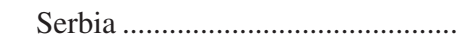 & 765 & 1,365 & - & 2,130 \\
\hline Slovakia................................... & 30,000 & 1,215 & 328 & 30,887 \\
\hline Slovenia...................................... & - & 1,800 & - & 1,800 \\
\hline 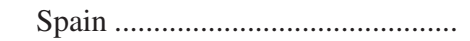 & - & 21,192 & 19 & 21,173 \\
\hline United Kingdom....... & - & 4,320 & 16 & 4,304 \\
\hline Total ..................... & $1,000,150$ & 160,488 & 222,230 & 938,408 \\
\hline Oceania: Australia......................... & - & 1,556 & - & 1,556 \\
\hline \multicolumn{5}{|l|}{ South America: } \\
\hline Argentina.................................. & 301 & 6,549 & - & 6,850 \\
\hline Bolivia ............ & - & 1,818 & - & 1,818 \\
\hline Brazil ........... & 208,447 & 38,941 & 63,165 & 184,223 \\
\hline Chile................... & - & 9,198 & - & 9,198 \\
\hline Colombia................................. & 3,000 & 16,650 & - & 19,650 \\
\hline Ecuador ....................................... & - & 1,348 & - & 1,348 \\
\hline 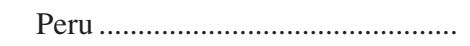 & - & 4,078 & - & 4,078 \\
\hline 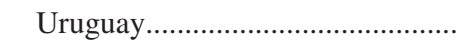 & - & 1,511 & - & 1,511 \\
\hline Venezuela .................................... & - & 2,214 & - & 2,214 \\
\hline Total .............. & 211,748 & 82,307 & 63,165 & 230,890 \\
\hline Grand total ....................... & $2,370,552$ & $1,140,469$ & 960,557 & $2,550,464$ \\
\hline
\end{tabular}

\footnotetext{
${ }^{1}$ Apparent consumption calculated as production plus imports minus exports, not adjusted to account for
} changes in government and industry stocks. Negative values indicate shipments from stocks.

${ }^{2}$ Although Dubai is one of the seven United Arab Emirates, separate statistical data are available for that state. 
Table A14. Asbestos production, trade, and consumption in 1998.

[Data in metric tons. Term used: - , zero. Data are unrounded but are believed to be accurate to no more than three significant digits. Production, import, and export data from United Nations Statistics Division, 2005; Virta, 2005a]

\begin{tabular}{|c|c|c|c|c|}
\hline Region and country & Production & Imports & Exports & $\begin{array}{c}\text { Apparent } \\
\text { consumption }\end{array}$ \\
\hline \multicolumn{5}{|l|}{ Africa: } \\
\hline Algeria.................. & - & 3,993 & - & 3,993 \\
\hline 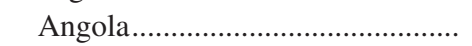 & - & 751 & - & 751 \\
\hline 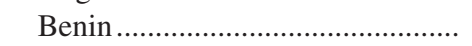 & - & 119 & - & 119 \\
\hline 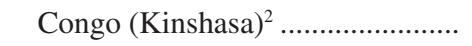 & - & 9 & - & 9 \\
\hline 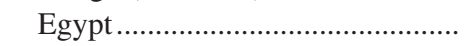 & 147 & 4,700 & - & 4,847 \\
\hline Gabon .................... & - & 1 & - & 1 \\
\hline Ghana ....... & - & 1,030 & - & 1,030 \\
\hline Kenya ..... & - & 174 & $\left({ }^{3}\right)$ & 174 \\
\hline Morocco ..... & - & 1,372 & - & 1,372 \\
\hline Nigeria... & - & 3,610 & - & 3,610 \\
\hline Senegal... & - & 736 & 419 & 317 \\
\hline South Africa. & 18,836 & 15,059 & 52,481 & $-18,586$ \\
\hline Swaziland. & 22,912 & - & 8,000 & 14,912 \\
\hline Togo ............. & - & 251 & - & 251 \\
\hline 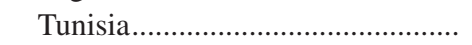 & - & 2,301 & - & 2,301 \\
\hline 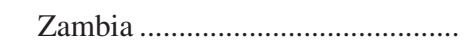 & - & 48,204 & - & 48,204 \\
\hline 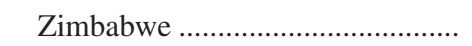 & 115,000 & - & 108,716 & 6,284 \\
\hline 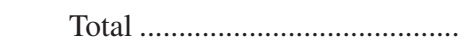 & 156,895 & 82,309 & 169,617 & 69,588 \\
\hline \multicolumn{5}{|l|}{ Asia and the Middle East: } \\
\hline 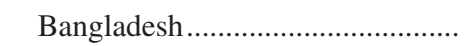 & - & 1,010 & - & 1,010 \\
\hline 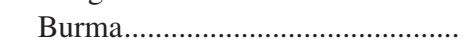 & - & 1,175 & - & 1,175 \\
\hline 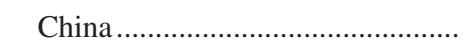 & 329,000 & 71,437 & 18,591 & 381,846 \\
\hline 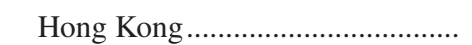 & - & 45 & - & 45 \\
\hline India & 20,000 & 109,036 & 348 & 128,688 \\
\hline 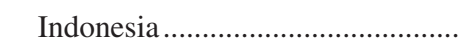 & - & 18,615 & 38 & 18,577 \\
\hline Iran & 2,258 & 36,693 & - & 38,951 \\
\hline 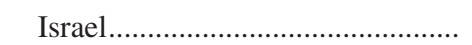 & - & 68 & - & 68 \\
\hline 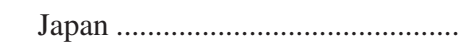 & 1,389 & 123,225 & 38 & 124,576 \\
\hline 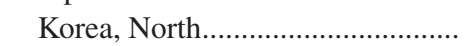 & - & 1,737 & - & 1,737 \\
\hline 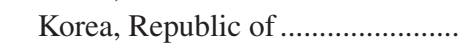 & - & 20,465 & 1 & 20,464 \\
\hline 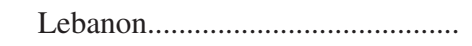 & - & 1,118 & 60 & 1,058 \\
\hline 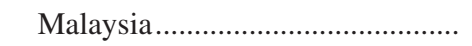 & - & 14,154 & 39 & 14,116 \\
\hline 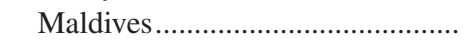 & - & 1 & - & 1 \\
\hline 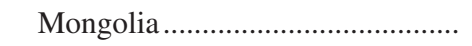 & - & 424 & - & 424 \\
\hline Oman & - & 290 & - & 290 \\
\hline Pakistan & - & 1,772 & - & 1,772 \\
\hline 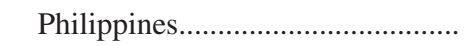 & - & 2,236 & - & 2,236 \\
\hline 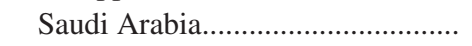 & - & 144 & - & 144 \\
\hline 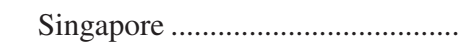 & - & 18 & 3 & 15 \\
\hline 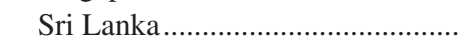 & - & 11,467 & - & 11,467 \\
\hline 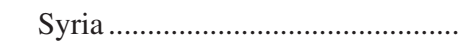 & - & 1,580 & - & 1,580 \\
\hline 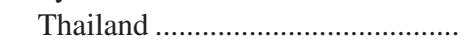 & - & 50,272 & - & 50,272 \\
\hline 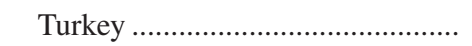 & - & 9,757 & - & 9,757 \\
\hline United Arab Emirates ....................... & - & 6,860 & - & 6,860 \\
\hline 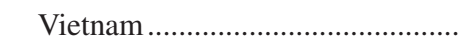 & - & 36,507 & - & 36,507 \\
\hline 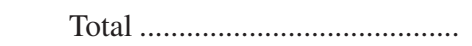 & 352,647 & 520,106 & 19,116 & 853,636 \\
\hline
\end{tabular}


Table A14. Asbestos production, trade, and consumption in 1998.-Continued

[Data in metric tons. Term used: - zero. Data are unrounded but are believed to be accurate to no more than three significant digits. Production, import, and export data from United Nations Statistics Division, 2005; Virta, 2005a]

\begin{tabular}{|c|c|c|c|c|}
\hline Region and country & Production & Imports & Exports & $\begin{array}{c}\text { Apparent } \\
\text { consumption' }\end{array}$ \\
\hline \multicolumn{5}{|l|}{ Central and North America: } \\
\hline 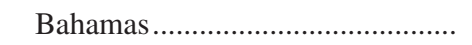 & - & $\left({ }^{3}\right)$ & 1 & -1 \\
\hline Canada....... & 337,000 & 186 & 319,430 & 17,756 \\
\hline 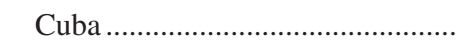 & - & 6,908 & - & 6,908 \\
\hline Dominican Republic ........................... & - & 976 & - & 976 \\
\hline 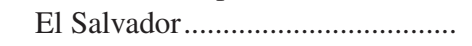 & - & 1,680 & $\left({ }^{3}\right)$ & 1,680 \\
\hline 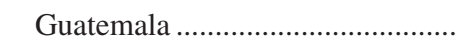 & - & - & 4 & -4 \\
\hline 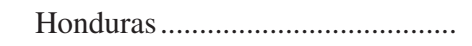 & - & 6 & - & 6 \\
\hline 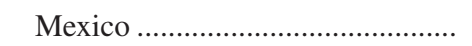 & - & 35,068 & - & 35,068 \\
\hline 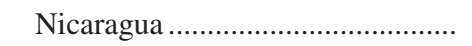 & - & 26 & - & 26 \\
\hline Panama & - & 990 & - & 990 \\
\hline United States ................ & 7,190 & 15,824 & 18,896 & 4,118 \\
\hline 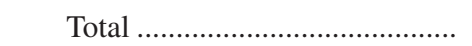 & 344,190 & 61,664 & 338,331 & 67,523 \\
\hline \multicolumn{5}{|l|}{ Europe: } \\
\hline Armenia $^{4}$. & - & 435 & - & 435 \\
\hline Austria........... & - & 7 & 3 & 4 \\
\hline Azerbaijan $^{4}$...................... & - & 1,364 & - & 1,364 \\
\hline 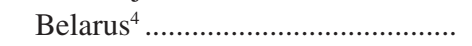 & - & - & 3,604 & $-3,604$ \\
\hline Belgium and Luxembourg ............ & - & - & 685 & -685 \\
\hline Bosnia and Herzegovina $^{5}$.................. & - & 12 & - & 12 \\
\hline 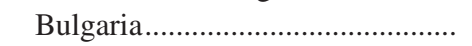 & 350 & 1,673 & $\left({ }^{3}\right)$ & 2,023 \\
\hline 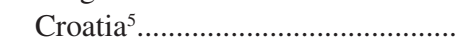 & - & 948 & 12 & 936 \\
\hline 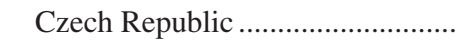 & - & 5,522 & 51 & 5,471 \\
\hline 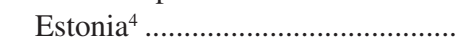 & - & 301 & - & 301 \\
\hline 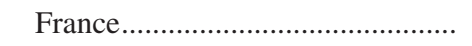 & - & 74 & - & 74 \\
\hline 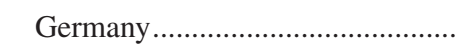 & - & 256 & - & 256 \\
\hline Greece ............ & 35,068 & 715 & 35,361 & 422 \\
\hline 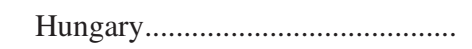 & - & 2,750 & - & 2,750 \\
\hline Ireland .......... & - & 630 & $\left({ }^{3}\right)$ & 630 \\
\hline Italy ................ & - & 1 & 7 & -6 \\
\hline Kazakhstan ${ }^{4} .$. & 139,300 & 394 & 123,906 & 15,788 \\
\hline Kyrgyzstan ${ }^{4}$.. & - & 16,421 & - & 16,421 \\
\hline Latvia $^{4} \ldots \ldots \ldots$ & - & 1,123 & 40 & 1,083 \\
\hline Lithuania $^{4} .$. & - & 2,439 & 2,982 & -543 \\
\hline Moldova $^{4} \ldots$ & - & 6,229 & - & 6,229 \\
\hline 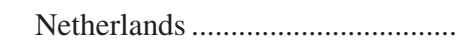 & - & 7 & - & 7 \\
\hline Poland & - & 5,174 & 323 & 4,850 \\
\hline 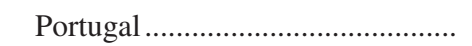 & - & 6,666 & $\left({ }^{3}\right)$ & 6,666 \\
\hline 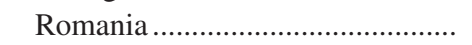 & - & 15,494 & - & 15,494 \\
\hline 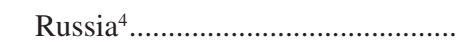 & 675,000 & 36,583 & 238,131 & 473,452 \\
\hline 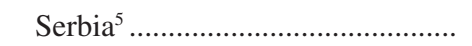 & 361 & - & - & 361 \\
\hline 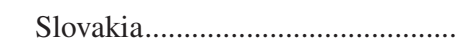 & - & 1,764 & 1 & 1,763 \\
\hline 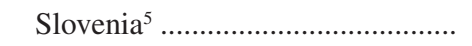 & - & 1,685 & - & 1,685 \\
\hline Spain & - & 21,819 & 15 & 21,804 \\
\hline 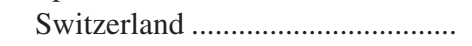 & - & - & $\left({ }^{3}\right)$ & $\left({ }^{3}\right)$ \\
\hline 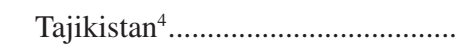 & - & 656 & - & 656 \\
\hline Turkmenistan ${ }^{4}$. & - & 5,752 & - & 5,752 \\
\hline
\end{tabular}


Table A14. Asbestos production, trade, and consumption in 1998.-Continued

[Data in metric tons. Term used: - , zero. Data are unrounded but are believed to be accurate to no more than three significant digits. Production, import, and export data from United Nations Statistics Division, 2005; Virta, 2005a]

\begin{tabular}{|c|c|c|c|c|}
\hline Region and country & Production & Imports & Exports & $\begin{array}{c}\text { Apparent } \\
\text { consumption }\end{array}$ \\
\hline \multicolumn{5}{|l|}{ Europe (continued): } \\
\hline Ukraine $^{4}$................. & - & 71,516 & - & 71,516 \\
\hline United Kingdom................................. & - & 1,861 & 45 & 1,815 \\
\hline 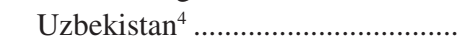 & - & 26,480 & - & 26,480 \\
\hline 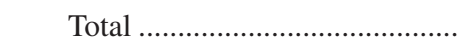 & 850,079 & 236,752 & 405,166 & 681,665 \\
\hline Oceania: Australia.......... & - & 1,550 & - & 1,550 \\
\hline \multicolumn{5}{|l|}{ South America: } \\
\hline Argentina....... & 259 & 5,028 & 1,052 & 4,235 \\
\hline Bolivia....... & - & 2,520 & - & 2,520 \\
\hline Brazil...... & 188,386 & 37,715 & 51,243 & 174,859 \\
\hline Chile.......... & - & 4,937 & - & 4,937 \\
\hline Colombia..... & 5,000 & 18,095 & - & 23,095 \\
\hline 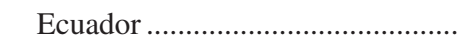 & - & 2,499 & - & 2,499 \\
\hline 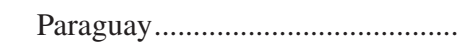 & - & 1 & - & 1 \\
\hline 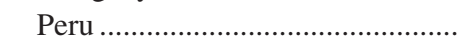 & - & 2,875 & - & 2,875 \\
\hline 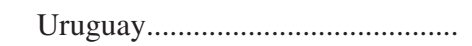 & - & 1,309 & - & 1,309 \\
\hline 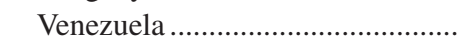 & - & 1,664 & 13 & 1,651 \\
\hline Total & 193,645 & 76,644 & 52,308 & 217,981 \\
\hline Unknown trade destinations.............. & - & 4,393 & - & 4,393 \\
\hline 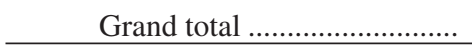 & $1,897,456$ & 983,417 & 984,537 & $1,896,336$ \\
\hline
\end{tabular}

${ }^{1}$ Apparent consumption calculated as production plus imports minus exports, not adjusted to account for changes in government and industry stocks. Negative values indicate shipments from stocks.

${ }^{2}$ Belgian Congo became Zaire between 1960 and 1998 and the Democratic Republic of the Congo [or Congo (Kinshasa)] after 1998.

${ }^{3}$ Less than $0.5 \mathrm{t}$.

${ }^{4}$ Data from Armenia, Azerbaijan, Belarus, Estonia, Kazakhstan, Kyrgyzstan, Latvia, Lithuania, Moldova, Russia, Tajikistan, Turkmenistan, Ukraine, and Uzbekistan became available after the dissolution of the Soviet Union in 1991. Both Asian and European countries of the former Soviet Union are listed under Europe to facilitate comparison of regional totals for different time periods.

${ }^{5}$ Data for Bosnia and Herzegovina, Croatia, Serbia, and Slovenia were combined under Yugoslavia before 1991. 
Table A15. Asbestos production, trade, and consumption in 1999.

[Data in metric tons. Term used: - , zero. Data are unrounded but are believed to be accurate to no more than three significant digits. Production, import, and export data from United Nations Statistics Division, 2005; Virta, 2005a]

\begin{tabular}{|c|c|c|c|c|}
\hline Region and country & Production & Imports & Exports & $\begin{array}{c}\text { Apparent } \\
\text { consumption }^{1}\end{array}$ \\
\hline \multicolumn{5}{|l|}{ Africa: } \\
\hline Algeria.... & - & 11,875 & - & 11,875 \\
\hline Angola... & - & 920 & - & 920 \\
\hline Benin .... & - & 154 & - & 154 \\
\hline Congo (Kinshasa).... & - & 10 & - & 10 \\
\hline Egypt ........ & - & 2,838 & - & 2,838 \\
\hline Ghana ...... & - & 66 & - & 66 \\
\hline Guinea ....... & - & 20 & - & 20 \\
\hline 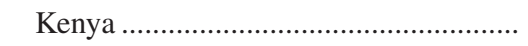 & - & 57 & 32 & 25 \\
\hline 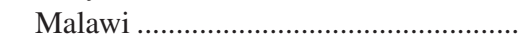 & - & 1 & - & 1 \\
\hline 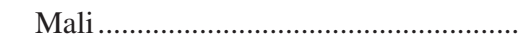 & - & 240 & - & 240 \\
\hline 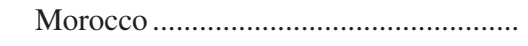 & - & 922 & - & 922 \\
\hline 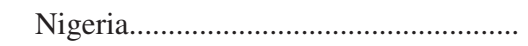 & - & 79,370 & - & 79,370 \\
\hline 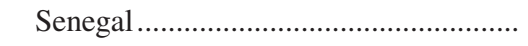 & - & 1,261 & 581 & 680 \\
\hline 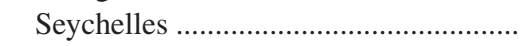 & - & 2 & - & 2 \\
\hline 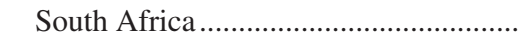 & 18,782 & 17,268 & 44,794 & $-8,743$ \\
\hline 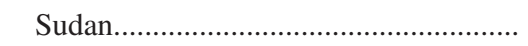 & - & 88 & $\left({ }^{2}\right)$ & 88 \\
\hline 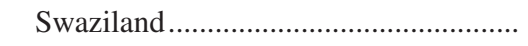 & 12,690 & - & 7,000 & 5,690 \\
\hline 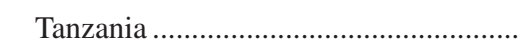 & - & 18 & - & 18 \\
\hline 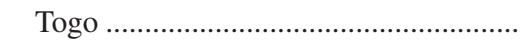 & - & 341 & - & 341 \\
\hline 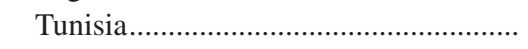 & - & 3,190 & - & 3,190 \\
\hline Uganda & - & 30 & - & 30 \\
\hline Zambia & - & 1,736 & - & 1,736 \\
\hline 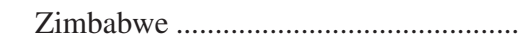 & 152,000 & 37 & 152,658 & -620 \\
\hline 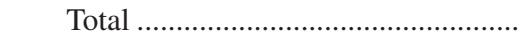 & 183,472 & 120,444 & 205,064 & 98,852 \\
\hline \multicolumn{5}{|l|}{ Asia and the Middle East: } \\
\hline Bangladesh ..................... & - & 1,425 & - & 1,425 \\
\hline China & 315,000 & 66,082 & 10,720 & 370,363 \\
\hline 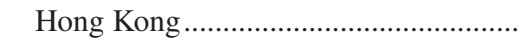 & - & 425 & - & 425 \\
\hline India & 21,000 & 115,220 & 172 & 136,048 \\
\hline 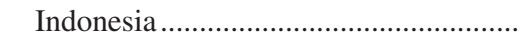 & - & 29,263 & 198 & 29,065 \\
\hline Iran ............... & 2,000 & 44,587 & 1 & 46,586 \\
\hline Iraq & - & 146 & - & 146 \\
\hline Israel........ & - & 17 & - & 17 \\
\hline 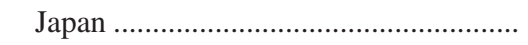 & - & 114,951 & 20 & 114,931 \\
\hline 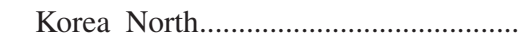 & - & 357 & - & 357 \\
\hline 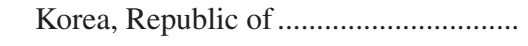 & - & 33,101 & 3 & 33,097 \\
\hline 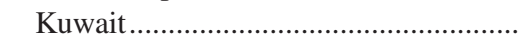 & - & 18 & - & 18 \\
\hline 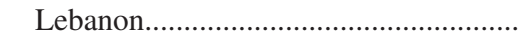 & - & 1,310 & - & 1,310 \\
\hline 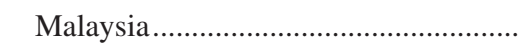 & - & 16,361 & 1 & 16,360 \\
\hline 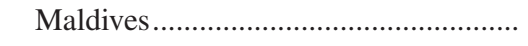 & - & 1 & - & 1 \\
\hline 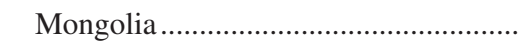 & - & 5 & - & 5 \\
\hline 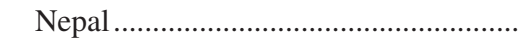 & - & 100 & - & 100 \\
\hline Oman & - & 18 & - & 18 \\
\hline 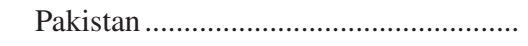 & - & 2,509 & - & 2,509 \\
\hline 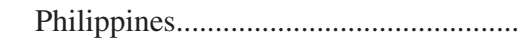 & - & 2,755 & - & 2,755 \\
\hline
\end{tabular}


Table A15. Asbestos production, trade, and consumption in 1999.-Continued

[Data in metric tons. Term used: - , zero. Data are unrounded but are believed to be accurate to no more than three significant digits. Production, import, and export data from United Nations Statistics Division, 2005; Virta, 2005a]

\begin{tabular}{|c|c|c|c|c|}
\hline Region and country & Production & Imports & Exports & $\begin{array}{c}\text { Apparent } \\
\text { consumption }\end{array}$ \\
\hline \multicolumn{5}{|l|}{ Asia and the Middle East (continued): } \\
\hline Saudi Arabia.... & - & 288 & 17,970 & $-17,682$ \\
\hline Singapore & - & 4,733 & 22 & 4,711 \\
\hline 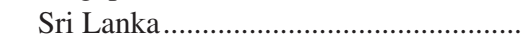 & - & 15,716 & $\left({ }^{2}\right)$ & 15,716 \\
\hline Syria & - & 2,050 & - & 2,050 \\
\hline 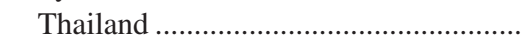 & - & 71,488 & - & 71,488 \\
\hline 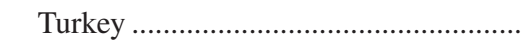 & - & 17,108 & 60 & 17,048 \\
\hline United Arab Emirates .............................. & - & 10,441 & - & 10,441 \\
\hline 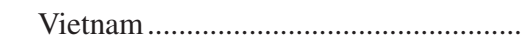 & - & 2,569 & - & 2,569 \\
\hline 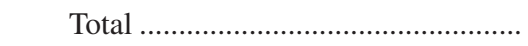 & 338,000 & 553,042 & 29,166 & 861,876 \\
\hline \multicolumn{5}{|l|}{ Central and North America: } \\
\hline 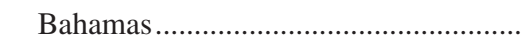 & - & 14 & - & 14 \\
\hline Canada... & 309,719 & 150 & 332,406 & $-22,537$ \\
\hline Cuba....... & - & 8,687 & - & 8,687 \\
\hline Dominican Republic ................................. & - & 600 & - & 600 \\
\hline El Salvador ..................... & - & 1,042 & - & 1,042 \\
\hline Guatemala .................. & - & 18 & 1 & 17 \\
\hline Honduras.... & - & 1 & - & 1 \\
\hline Mexico ......... & - & 37,791 & 3 & 37,788 \\
\hline Panama ............. & - & 962 & - & 962 \\
\hline United States. & 5,260 & 14,508 & ${ }^{3} 5,260$ & 14,508 \\
\hline Total ............. & 314,979 & 63,773 & 337,670 & 41,082 \\
\hline \multicolumn{5}{|l|}{ Europe: } \\
\hline Albania.................. & - & 4 & - & 4 \\
\hline Armenia $^{4}$ & - & 592 & - & 592 \\
\hline 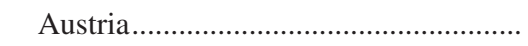 & - & $\left({ }^{2}\right)$ & - & $\left({ }^{2}\right)$ \\
\hline 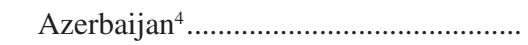 & - & 824 & - & 824 \\
\hline 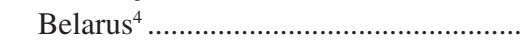 & - & - & 4,334 & $-4,334$ \\
\hline Belgium and Luxembourg ....................... & - & 509 & 1 & 508 \\
\hline Bosnia and Herzegovina ............................ & - & 8 & - & 8 \\
\hline 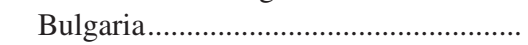 & 350 & 781 & - & 1,131 \\
\hline 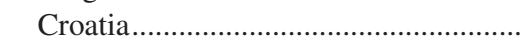 & - & 701 & 8 & 693 \\
\hline 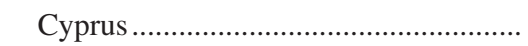 & - & 60 & 41 & 19 \\
\hline 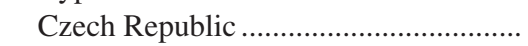 & - & 712 & 1 & 711 \\
\hline 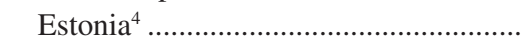 & - & 728 & 578 & 150 \\
\hline 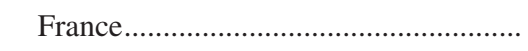 & - & 6 & - & 6 \\
\hline Georgia $^{4} \ldots \ldots \ldots$ & - & 591 & 592 & -1 \\
\hline 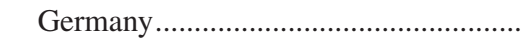 & - & 998 & - & 998 \\
\hline 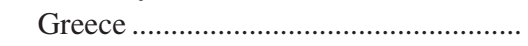 & - & 79 & 28,408 & $-28,328$ \\
\hline 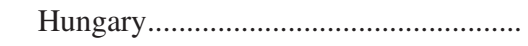 & - & 809 & - & 809 \\
\hline Ireland & - & 6 & - & 6 \\
\hline Italy & - & - & $\left({ }^{2}\right)$ & $\left({ }^{2}\right)$ \\
\hline 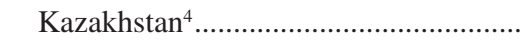 & 233,200 & 421 & 109,739 & 123,882 \\
\hline 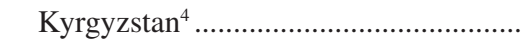 & - & 9,176 & - & 9,176 \\
\hline Latvia $^{4} \ldots \ldots \ldots \ldots$ & - & 399 & - & 399 \\
\hline 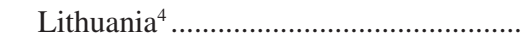 & - & 858 & 3,967 & $-3,109$ \\
\hline Moldova $^{4} .$. & - & 4,129 & - & 4,129 \\
\hline
\end{tabular}


Table A15. Asbestos production, trade, and consumption in 1999._Continued

[Data in metric tons. Term used: — , zero. Data are unrounded but are believed to be accurate to no more than three significant digits. Production, import, and export data from United Nations Statistics Division, 2005; Virta, 2005a]

\begin{tabular}{|c|c|c|c|c|}
\hline Region and country & Production & Imports & Exports & $\begin{array}{c}\text { Apparent } \\
\text { consumption' }\end{array}$ \\
\hline \multicolumn{5}{|l|}{ Europe (continued): } \\
\hline Netherlands ................................... & - & 1 & - & 1 \\
\hline 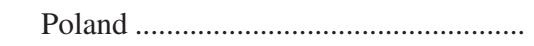 & - & 537 & - & 537 \\
\hline Portugal ........................................... & - & 7,749 & 4 & 7,745 \\
\hline Romania ............................ & - & 12,628 & 4 & 12,624 \\
\hline Russia $^{4} \ldots \ldots \ldots \ldots \ldots \ldots \ldots \ldots$ & 750,000 & 24,556 & 262,557 & 511,999 \\
\hline Serbia and Montenegro ..................... & 563 & 127 & - & 690 \\
\hline 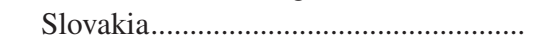 & - & 1,290 & - & 1,290 \\
\hline Slovenia............................................ & - & 1,492 & - & 1,492 \\
\hline Spain ......................... & - & 18,452 & 5 & 18,447 \\
\hline 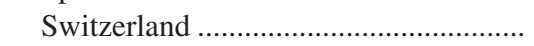 & - & 10 & $\left({ }^{2}\right)$ & 10 \\
\hline Turkmenistan $^{4}$.................... & - & 1,683 & - & 1,683 \\
\hline Ukraine $^{4} \ldots \ldots \ldots \ldots$ & - & 77,269 & - & 77,269 \\
\hline United Kingdom............................. & - & 578 & 49 & 529 \\
\hline 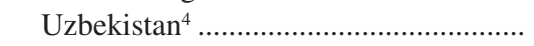 & - & 35,609 & - & 35,609 \\
\hline Total ................ & 984,113 & 204,372 & 410,288 & 778,197 \\
\hline Oceania: Australia................................... & - & 1,429 & 12 & 1,417 \\
\hline \multicolumn{5}{|l|}{ South America: } \\
\hline Argentina...................... & 254 & 2,603 & 12 & 2,845 \\
\hline 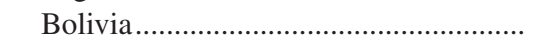 & - & 802 & - & 802 \\
\hline Brazil................. & 209,332 & 12,686 & 49,419 & 172,598 \\
\hline Chile .......................... & - & 2,296 & - & 2,296 \\
\hline Colombia......................................... & 5,000 & 12,497 & $\left({ }^{2}\right)$ & 17,497 \\
\hline Ecuador .......................................... & - & 4,299 & - & 4,299 \\
\hline Peru ............................ & - & 1,386 & - & 1,386 \\
\hline Suriname $^{5} \ldots \ldots \ldots \ldots . .$. & - & 234 & - & 234 \\
\hline Uruguay........................................ & - & 1,239 & - & 1,239 \\
\hline Venezuela ........................................ & - & 2,441 & - & 2,441 \\
\hline Total ....................... & 214,586 & 40,482 & 49,431 & 205,637 \\
\hline Unknown trade destinations.................... & - & 22,195 & - & 22,195 \\
\hline 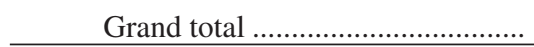 & $2,035,150$ & $1,005,738$ & $1,031,633$ & $2,009,255$ \\
\hline
\end{tabular}

${ }^{1}$ Apparent consumption calculated as production plus imports minus exports, not adjusted to account for changes in government and industry stocks. Negative values indicate shipments from stocks.

${ }^{2}$ Less than $0.5 \mathrm{t}$.

${ }^{3}$ Includes exports and reexports of asbestos fiber.

${ }^{4}$ Data for Armenia, Azerbaijan, Belarus, Estonia, Georgia, Kazakhstan, Kyrgyzstan, Latvia, Lithuania, Moldova, Russia, Turkmenistan, Ukraine, and Uzbekistan became available after the dissolution of the Soviet Union in 1991. Both Asian and European countries of the former Soviet Union are listed under Europe to facilitate comparison of regional totals for different time periods.

${ }^{5}$ Dutch Guiana and Netherlands Guiana became Suriname after 1975. 
Table A16. Asbestos production, trade, and consumption in 2000.

[Data in metric tons. Term used: - , zero. Data are unrounded but are believed to be accurate to no more than three significant digits. Production, import, and export data from United Nations Statistics Division, 2005; Virta, 2005a]

\begin{tabular}{|c|c|c|c|c|}
\hline Region and country & Production & Imports & Exports & $\begin{array}{c}\text { Apparent } \\
\text { consumption }{ }^{1}\end{array}$ \\
\hline \multicolumn{5}{|l|}{ Africa: } \\
\hline 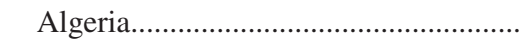 & - & 7,611 & - & 7,611 \\
\hline 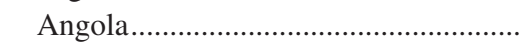 & - & 1,520 & - & 1,520 \\
\hline 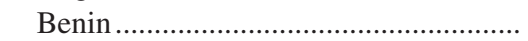 & - & 52 & - & 52 \\
\hline 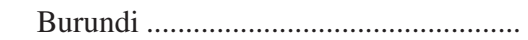 & - & 200 & - & 200 \\
\hline 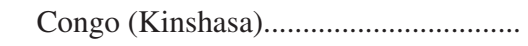 & - & 122 & - & 122 \\
\hline 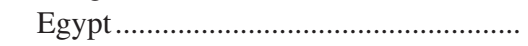 & - & 1,912 & - & 1,912 \\
\hline Ghana ......... & - & 1,071 & - & 1,071 \\
\hline Kenya ............. & - & 27 & 1 & 27 \\
\hline Malawi ...... & - & 15 & - & 15 \\
\hline Mauritius .......... & - & 42 & - & 42 \\
\hline Morocco ........ & - & 2,232 & - & 2,232 \\
\hline Mozambique . & - & 128 & - & 128 \\
\hline Namibia........... & - & - & $\left({ }^{2}\right)$ & $\left({ }^{2}\right)$ \\
\hline Niger ................ & - & 40 & - & 40 \\
\hline 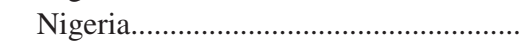 & - & 7,222 & - & 7,222 \\
\hline 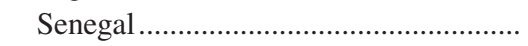 & - & 1,277 & 147 & 1,130 \\
\hline 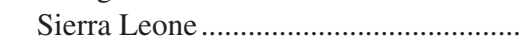 & - & 1 & - & 1 \\
\hline 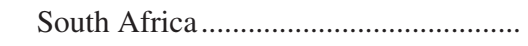 & 18,782 & 10,842 & 34,695 & $-5,071$ \\
\hline 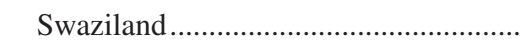 & 12,690 & - & 6,933 & 5,757 \\
\hline 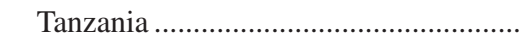 & - & 18 & - & 18 \\
\hline Togo & - & 32 & - & 32 \\
\hline 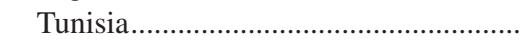 & - & 2,200 & 144 & 2,056 \\
\hline 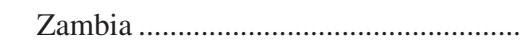 & - & 871 & - & 871 \\
\hline Zimbabwe ..................... & 152,000 & - & 64,583 & 87,417 \\
\hline Total .............................. & 183,472 & 37,436 & 106,502 & 114,406 \\
\hline \multicolumn{5}{|l|}{ Asia and the Middle East: } \\
\hline Bangladesh ........................ & - & 1,445 & - & 1,445 \\
\hline Burma................................. & - & 100 & - & 100 \\
\hline China & 315,000 & 79,129 & 11,814 & 382,315 \\
\hline 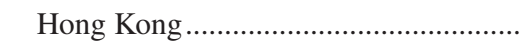 & - & 1,135 & - & 1,135 \\
\hline India & 21,000 & 124,433 & 403 & 145,030 \\
\hline 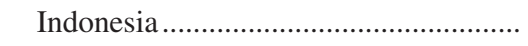 & - & 42,877 & - & 42,877 \\
\hline Iran & 2,000 & 38,707 & - & 40,707 \\
\hline Israel....................... & - & 20 & - & 20 \\
\hline 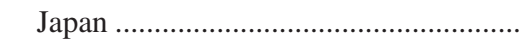 & - & 85,440 & - & 85,440 \\
\hline 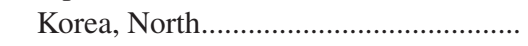 & - & 848 & - & 848 \\
\hline 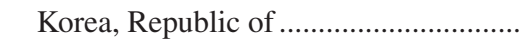 & - & 30,135 & 12 & 30,124 \\
\hline Lebanon.................... & - & 975 & - & 975 \\
\hline 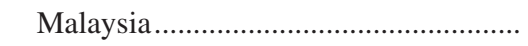 & - & 17,711 & - & 17,711 \\
\hline Maldives................... & - & 2 & - & 2 \\
\hline 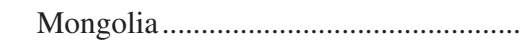 & - & 690 & - & 690 \\
\hline Oman & - & 1 & 180 & -179 \\
\hline 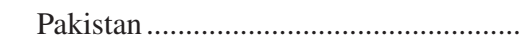 & - & 1,589 & - & 1,589 \\
\hline 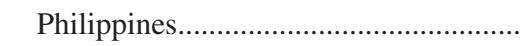 & - & 2,631 & - & 2,631 \\
\hline 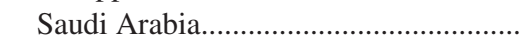 & - & 68 & 9,733 & $-9,664$ \\
\hline 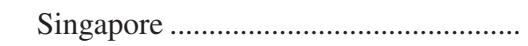 & - & 3,014 & 24 & 2,990 \\
\hline 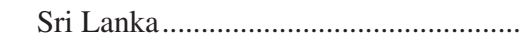 & - & 12,640 & - & 12,640 \\
\hline
\end{tabular}


Table A16. Asbestos production, trade, and consumption in 2000.-Continued

[Data in metric tons. Term used: - , zero. Data are unrounded but are believed to be accurate to no more than three significant digits. Production, import, and export data from United Nations Statistics Division, 2005;

Virta, 2005a]

\begin{tabular}{|c|c|c|c|c|}
\hline Region and country & Production & Imports & Exports & $\begin{array}{c}\text { Apparent } \\
\text { consumption }\end{array}$ \\
\hline \multicolumn{5}{|l|}{ Asia and the Middle East (continued): } \\
\hline 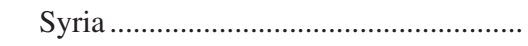 & - & 2,010 & - & 2,010 \\
\hline 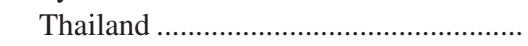 & - & 109,600 & - & 109,600 \\
\hline 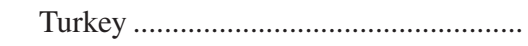 & - & 27,569 & - & 27,569 \\
\hline 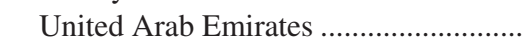 & - & 10,221 & 1 & 10,220 \\
\hline 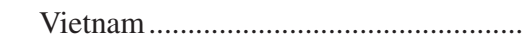 & - & 44,150 & - & 44,150 \\
\hline Yemen & - & 172 & - & 172 \\
\hline Total . & 338,000 & 637,310 & 22,165 & 953,145 \\
\hline \multicolumn{5}{|l|}{ Central and North America: } \\
\hline 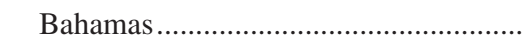 & - & 515 & - & 515 \\
\hline 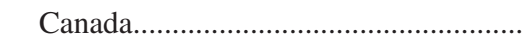 & 309,719 & 22 & 314,706 & $-4,965$ \\
\hline 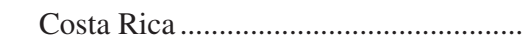 & - & 109 & - & 109 \\
\hline 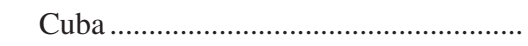 & - & 5,512 & - & 5,512 \\
\hline 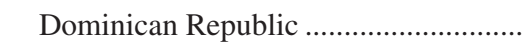 & - & 200 & - & 200 \\
\hline 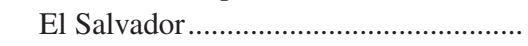 & - & 1,460 & 2 & 1,458 \\
\hline 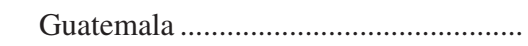 & - & 20 & 2 & 18 \\
\hline 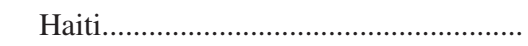 & - & 17 & - & 17 \\
\hline 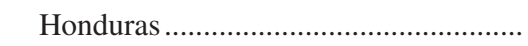 & - & 2 & - & 2 \\
\hline 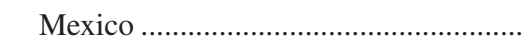 & - & 36,945 & 1 & 36,945 \\
\hline 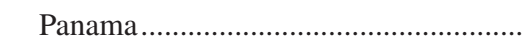 & - & 1,280 & - & 1,280 \\
\hline 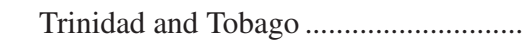 & - & - & $\left({ }^{2}\right)$ & $\left({ }^{2}\right)$ \\
\hline 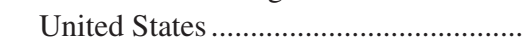 & 5,260 & 14,849 & ${ }^{3} 18,975$ & 1,134 \\
\hline Total . & 314,979 & 60,932 & 333,686 & 42,225 \\
\hline \multicolumn{5}{|l|}{ Europe: } \\
\hline Austria......... & - & - & 5 & -5 \\
\hline Azerbaijan .......................... & - & 7,149 & - & 7,149 \\
\hline 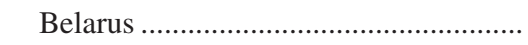 & - & - & 65 & -65 \\
\hline Belgium and Luxembourg ....................... & - & - & $\left({ }^{2}\right)$ & $\left({ }^{2}\right)$ \\
\hline 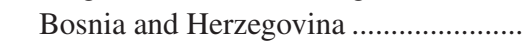 & - & 21 & - & 21 \\
\hline 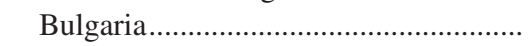 & 350 & 391 & 324 & 417 \\
\hline 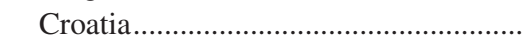 & - & 3,655 & - & 3,655 \\
\hline 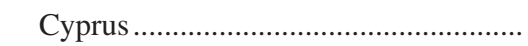 & - & 324 & $\left({ }^{2}\right)$ & 324 \\
\hline 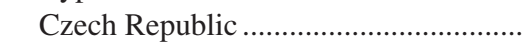 & - & 1,076 & - & 1,076 \\
\hline 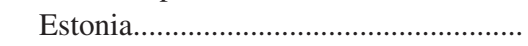 & - & 180 & $\left({ }^{2}\right)$ & 180 \\
\hline 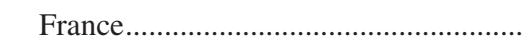 & - & 20 & 46 & -26 \\
\hline 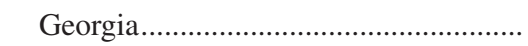 & - & 5 & - & 5 \\
\hline 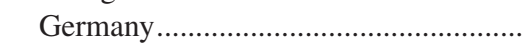 & - & 212 & - & 212 \\
\hline 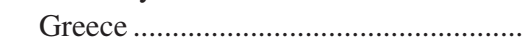 & - & 90 & 8,946 & $-8,856$ \\
\hline 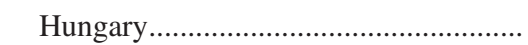 & - & 3,456 & - & 3,456 \\
\hline Ireland & - & - & $\left({ }^{2}\right)$ & $\left({ }^{2}\right)$ \\
\hline Italy & - & 40 & - & 40 \\
\hline 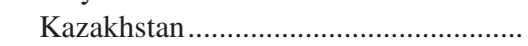 & 233,200 & 1,252 & 162,716 & 71,737 \\
\hline 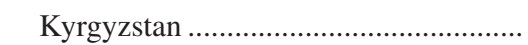 & - & 16,486 & - & 16,486 \\
\hline Latvia & - & 1,124 & - & 1,124 \\
\hline 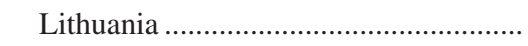 & - & 1,305 & 643 & 663 \\
\hline 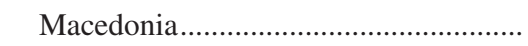 & - & 48 & - & 48 \\
\hline 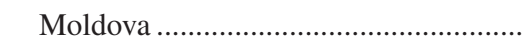 & - & 1,679 & - & 1,679 \\
\hline
\end{tabular}


Table A16. Asbestos production, trade, and consumption in 2000.-Continued

[Data in metric tons. Term used: —, zero. Data are unrounded but are believed to be accurate to no more than three significant digits. Production, import, and export data from United Nations Statistics Division, 2005; Virta, 2005a]

\begin{tabular}{|c|c|c|c|c|}
\hline Region and country & Production & Imports & Exports & $\begin{array}{c}\text { Apparent } \\
\text { consumption }^{1}\end{array}$ \\
\hline \multicolumn{5}{|l|}{ Europe (continued): } \\
\hline Netherlands ........... & - & 3 & - & 3 \\
\hline 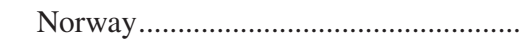 & - & 12 & - & 12 \\
\hline 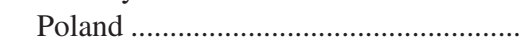 & - & 117 & - & 117 \\
\hline 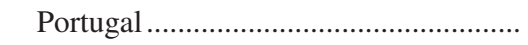 & - & 3,437 & 36 & 3,401 \\
\hline 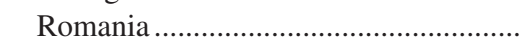 & - & 10,658 & - & 10,658 \\
\hline 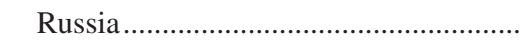 & 750,000 & 31,656 & 332,417 & 449,239 \\
\hline 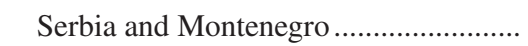 & 563 & 43 & 69 & 537 \\
\hline 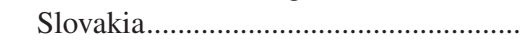 & - & 1,201 & - & 1,201 \\
\hline 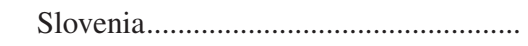 & - & 754 & - & 754 \\
\hline Spain & - & 13,060 & 126 & 12,934 \\
\hline Sweden & - & - & 12 & -12 \\
\hline 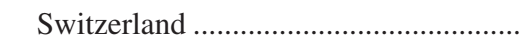 & - & - & $\left({ }^{2}\right)$ & $\left({ }^{2}\right)$ \\
\hline 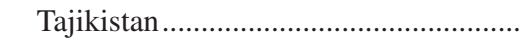 & - & 450 & - & 450 \\
\hline 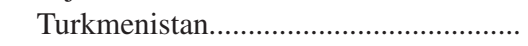 & - & 979 & $\left({ }^{2}\right)$ & 979 \\
\hline 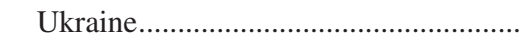 & - & 80,942 & - & 80,942 \\
\hline United Kingdom......... & - & 270 & 2 & 268 \\
\hline Uzbekistan.. & 一 & 43,374 & 一 & 43,374 \\
\hline Total ......... & 984,113 & 225,467 & 505,405 & 704,175 \\
\hline \multicolumn{5}{|l|}{ Oceania: } \\
\hline Australia... & - & 1,424 & - & 1,424 \\
\hline Tokelau............ & - & 212 & - & 212 \\
\hline Total ..... & - & 1,636 & - & 1,636 \\
\hline \multicolumn{5}{|l|}{ South America: } \\
\hline 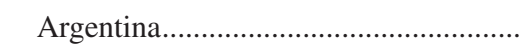 & 254 & 1,843 & 26 & 2,071 \\
\hline 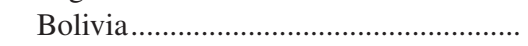 & - & 513 & - & 513 \\
\hline 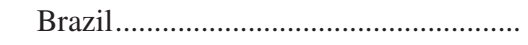 & 209,332 & 26,362 & 63,134 & 172,560 \\
\hline Chile & - & 1,969 & 158 & 1,811 \\
\hline 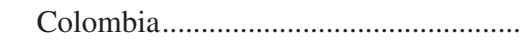 & 5,000 & 12,994 & 2 & 17,992 \\
\hline 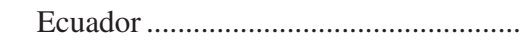 & - & 4,595 & - & 4,595 \\
\hline 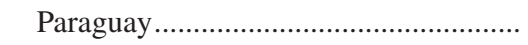 & - & 396 & - & 396 \\
\hline Peru & - & 1,275 & $\left({ }^{2}\right)$ & 1,275 \\
\hline 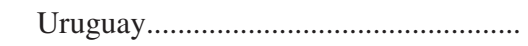 & - & 778 & - & 778 \\
\hline Venezuela ......................... & - & 2,943 & - & 2,943 \\
\hline 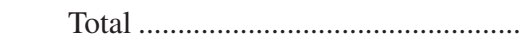 & 214,586 & 53,668 & 63,320 & 204,934 \\
\hline 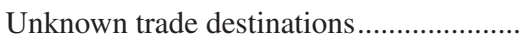 & - & 14,630 & - & 14,630 \\
\hline Grand total . & $2,035,150$ & $1,031,079$ & $1,031,079$ & $2,035,150$ \\
\hline
\end{tabular}

${ }^{1}$ Apparent consumption calculated as production plus imports minus exports, not adjusted to account for changes in government and industry stocks. Negative values indicate shipments from stocks.

${ }^{2}$ Less than $0.5 \mathrm{t}$.

${ }^{3}$ Includes exports and reexports of asbestos fiber. 
Table A17. Asbestos production, trade, and consumption in 2001.

[Data in metric tons. Term used: - , zero. Data are unrounded but are believed to be accurate to no more than three significant digits. Production, import, and export data from United Nations Statistics Division, 2005; Virta, 2005a]

\begin{tabular}{|c|c|c|c|c|}
\hline Region and country & Production & Imports & Exports & $\begin{array}{c}\text { Apparent } \\
\text { consumption }{ }^{1}\end{array}$ \\
\hline \multicolumn{5}{|l|}{ Africa: } \\
\hline (1) & - & 5,813 & - & 5,813 \\
\hline Angola....................... & - & 260 & - & 260 \\
\hline 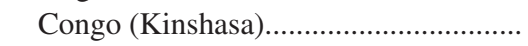 & - & 24 & - & 24 \\
\hline 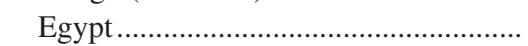 & - & 2,145 & - & 2,145 \\
\hline 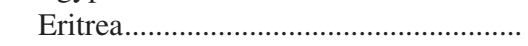 & - & 8 & - & 8 \\
\hline Ghana & - & 18 & - & 18 \\
\hline Kenya & - & 96 & $\left({ }^{2}\right)$ & 96 \\
\hline 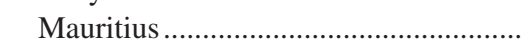 & - & 18 & - & 18 \\
\hline 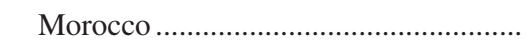 & - & 414 & - & 414 \\
\hline 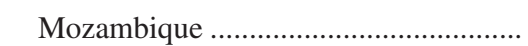 & - & 200 & - & 200 \\
\hline 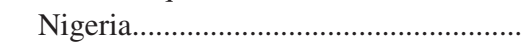 & - & 2,146 & - & 2,146 \\
\hline 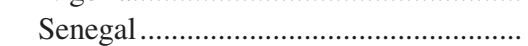 & - & 1,190 & 8 & 1,182 \\
\hline Sierra Leone ................. & - & 397 & - & 397 \\
\hline 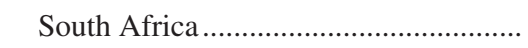 & 13,393 & 18,961 & 21,456 & 10,898 \\
\hline 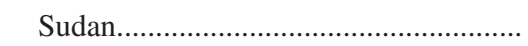 & - & 21 & - & 21 \\
\hline 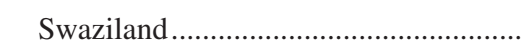 & - & - & 7,894 & $-7,894$ \\
\hline Tanzania .......... & - & $\left({ }^{2}\right)$ & - & $\left({ }^{2}\right)$ \\
\hline Tunisia............................. & - & 700 & - & 700 \\
\hline Uganda ................... & - & - & 9 & -9 \\
\hline 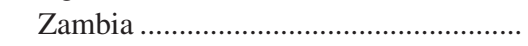 & - & 1,225 & - & 1,225 \\
\hline 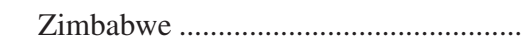 & 136,327 & 32 & 85,033 & 51,326 \\
\hline Total .......................... & 149,720 & 33,670 & 114,401 & 68,989 \\
\hline \multicolumn{5}{|l|}{ Asia and the Middle East: } \\
\hline Bangladesh...................... & - & 1,266 & - & 1,266 \\
\hline 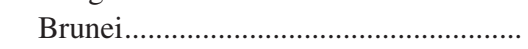 & - & 1 & - & 1 \\
\hline Burma..................... & - & 302 & - & 302 \\
\hline China .................... & 310,000 & 102,755 & 18,431 & 394,324 \\
\hline Hong Kong.. & - & 3,400 & - & 3,400 \\
\hline India ............... & 21,000 & 130,291 & 1,129 & 150,161 \\
\hline Indonesia ... & - & 38,566 & 4 & 38,562 \\
\hline Iran ............... & 2,000 & 42,391 & - & 44,391 \\
\hline . & - & 81 & - & 81 \\
\hline Japan ....................... & - & 78,304 & 57 & 78,247 \\
\hline 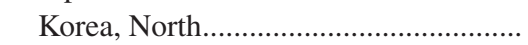 & - & 750 & - & 750 \\
\hline 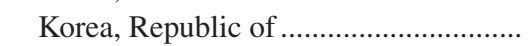 & - & 25,049 & 5 & 25,044 \\
\hline 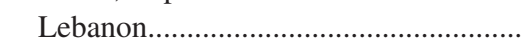 & - & 142 & - & 142 \\
\hline 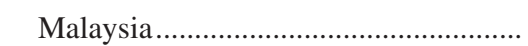 & - & 12,266 & 6,100 & 6,166 \\
\hline 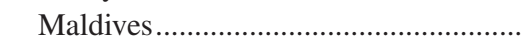 & - & $\left({ }^{2}\right)$ & - & $\left({ }^{2}\right)$ \\
\hline 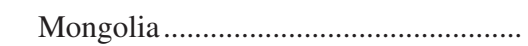 & - & 91 & $\left({ }^{2}\right)$ & 91 \\
\hline Oman & - & 1,799 & - & 1,799 \\
\hline Pakistan & - & 464 & - & 464 \\
\hline 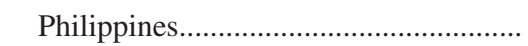 & - & 3,023 & - & 3,023 \\
\hline 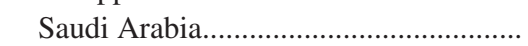 & - & 54 & 4,626 & $-4,573$ \\
\hline 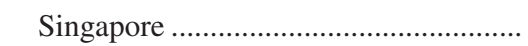 & - & 418 & 3 & 415 \\
\hline 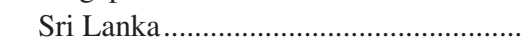 & - & 11,205 & 40 & 11,165 \\
\hline Syria & - & 1,197 & - & 1,197 \\
\hline
\end{tabular}


Table A17. Asbestos production, trade, and consumption in 2001.-Continued

[Data in metric tons. Term used: - , zero. Data are unrounded but are believed to be accurate to no more than three significant digits. Production, import, and export data from United Nations Statistics Division, 2005; Virta, 2005a]

\begin{tabular}{|c|c|c|c|c|}
\hline Region and country & Production & Imports & Exports & $\begin{array}{c}\text { Apparent } \\
\text { consumption' }\end{array}$ \\
\hline \multicolumn{5}{|l|}{ Asia and the Middle East (continued): } \\
\hline 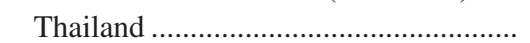 & - & 103,321 & 1 & 103,320 \\
\hline 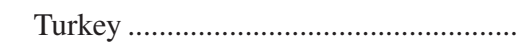 & - & 5,315 & 5 & 5,310 \\
\hline United Arab Emirates …………................. & - & 8,675 & - & 8,675 \\
\hline Vietnam....... & - & 24,905 & - & 24,905 \\
\hline Total ... & 333,000 & 596,030 & 30,402 & 898,627 \\
\hline \multicolumn{5}{|l|}{ Central and North America: } \\
\hline Bahamas ............................... & - & 19 & - & \\
\hline 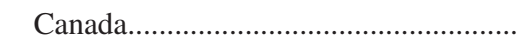 & 276,790 & 424 & 272,596 & 4,618 \\
\hline 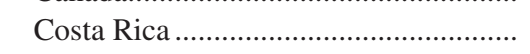 & - & 1 & - & \\
\hline 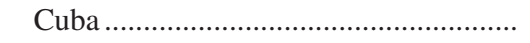 & - & 7,344 & - & 7,344 \\
\hline Dominican Republic ……………............... & - & 253 & - & 253 \\
\hline 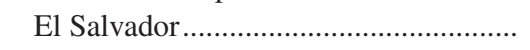 & - & 1,974 & - & 1,974 \\
\hline 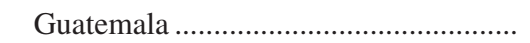 & - & 1 & 4 & 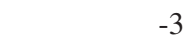 \\
\hline 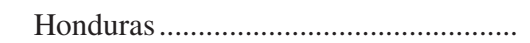 & - & 4 & - & \\
\hline Mexico & - & 28,075 & 3 & 28,072 \\
\hline Panama & - & 1,040 & - & 1,040 \\
\hline Trinidad and Tobago ………………............ & - & - & $\left({ }^{2}\right)$ & 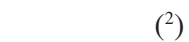 \\
\hline United States ............................................... & 5,260 & 12,760 & ${ }^{3} 14,748$ & 3,272 \\
\hline 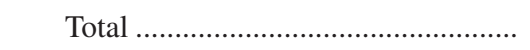 & 282,050 & 51,894 & 287,350 & 46,594 \\
\hline \multicolumn{5}{|l|}{ Europe: } \\
\hline Austria & - & 1 & - & \\
\hline 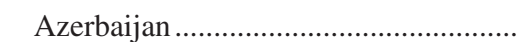 & - & 4,142 & - & 4,142 \\
\hline 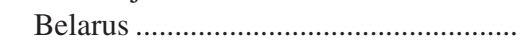 & - & 1,588 & 3 & 1,585 \\
\hline Belgium and Luxembourg ......................... & - & 1 & - & \\
\hline Bosnia and Herzegovina & - & 1 & - & \\
\hline$\ldots \ldots \ldots \ldots \ldots \ldots \ldots \ldots \ldots \ldots$ & - & 529 & 36 & 493 \\
\hline 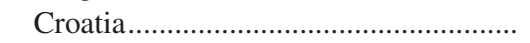 & - & 1,815 & $\left({ }^{2}\right)$ & 1,815 \\
\hline 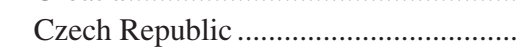 & - & 1,922 & - & 1,922 \\
\hline 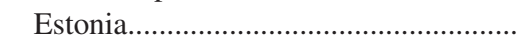 & - & 605 & 606 & -2 \\
\hline$\ldots$ & - & 17 & 59 & -42 \\
\hline Germany & - & 135 & - & 135 \\
\hline Greece. & - & 69 & 252 & -183 \\
\hline Hungary & - & 2,339 & - & 2,339 \\
\hline Ireland & - & - & 1 & -1 \\
\hline 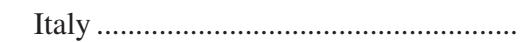 & - & 52 & - & 52 \\
\hline 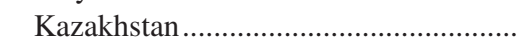 & 271,300 & 1,952 & 58,954 & 214,298 \\
\hline 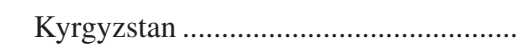 & - & 10,546 & - & 10,546 \\
\hline 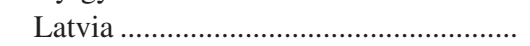 & - & 664 & - & 664 \\
\hline Lithuania & - & 105 & 139 & -34 \\
\hline Macedonia & - & 72 & 4 & 68 \\
\hline$\ldots$ & - & 170 & - & 170 \\
\hline 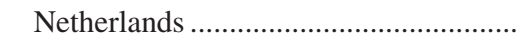 & - & 28 & - & 28 \\
\hline$\ldots \ldots \ldots \ldots \ldots \ldots . .$. & - & 948 & - & 948 \\
\hline 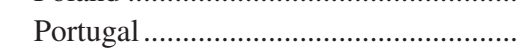 & - & 4,238 & $\left({ }^{2}\right)$ & 4,238 \\
\hline Romania & - & 13,278 & - & 13,278 \\
\hline Russia & 750,000 & 2,688 & 340,397 & 412,291 \\
\hline
\end{tabular}


Table A17. Asbestos production, trade, and consumption in 2001._Continued

[Data in metric tons. Term used: — , zero. Data are unrounded but are believed to be accurate to no more than three significant digits. Production, import, and export data from United Nations Statistics Division, 2005; Virta, 2005a]

\begin{tabular}{|c|c|c|c|c|}
\hline Region and country & Production & Imports & Exports & $\begin{array}{c}\text { Apparent } \\
\text { consumption' }\end{array}$ \\
\hline \multicolumn{5}{|l|}{ Europe (continued): } \\
\hline Serbia and Montenegro... & 194 & 101 & 75 & 221 \\
\hline 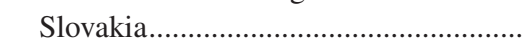 & - & 337 & - & 337 \\
\hline Slovenia.. & - & - & $\left({ }^{2}\right)$ & $\left({ }^{2}\right)$ \\
\hline Spain ........ & - & 13,963 & 36 & 13,927 \\
\hline Switzerland .. & - & 2,526 & $\left({ }^{2}\right)$ & 2,525 \\
\hline Turkmenistan... & - & 1,925 & - & 1,925 \\
\hline Ukraine.. & - & 55,220 & 228 & 54,992 \\
\hline United Kingdom......... & - & 179 & 1 & 178 \\
\hline Uzbekistan... & - & 26,609 & - & 26,609 \\
\hline Total & $1,021,494$ & 148,764 & 400,791 & 769,467 \\
\hline 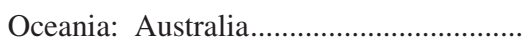 & - & 653 & - & 653 \\
\hline \multicolumn{5}{|l|}{ South America: } \\
\hline 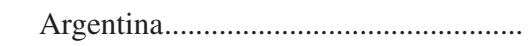 & 203 & 1,636 & - & 1,839 \\
\hline 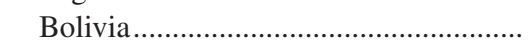 & - & 684 & - & 684 \\
\hline 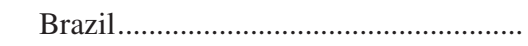 & 172,695 & 30,763 & 53,919 & 149,540 \\
\hline 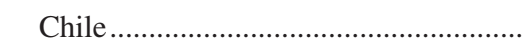 & - & 301 & - & 301 \\
\hline 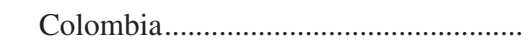 & 5,000 & 11,402 & 8 & 16,394 \\
\hline 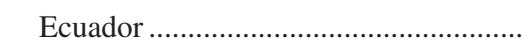 & - & 3,959 & - & 3,959 \\
\hline Peru & - & 920 & - & 920 \\
\hline 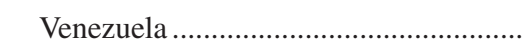 & - & 2,833 & 1 & 2,832 \\
\hline Total ......................... & 177,898 & 52,497 & 53,927 & 176,468 \\
\hline Unknown trade destinations...................... & - & 3,365 & - & 3,365 \\
\hline 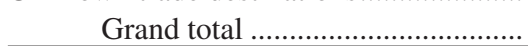 & $1,964,162$ & 886,874 & 886,873 & $1,964,164$ \\
\hline
\end{tabular}

${ }^{1}$ Apparent consumption calculated as production plus imports minus exports, not adjusted to account for changes in government and industry stocks. Negative values indicate shipments from stocks.

${ }^{2}$ Less than $0.5 \mathrm{t}$

${ }^{3}$ Includes exports and reexports of asbestos fiber. 
Table A18. Asbestos production, trade, and consumption in 2002.

[Data in metric tons. Terms used: NA, not available; - , zero. Data are unrounded but are believed to be accurate to no more than three significant digits. Production, import, and export data from United Nations Statistics Division, 2005; Virta, 2005a]

\begin{tabular}{|c|c|c|c|c|}
\hline Region and country & Production & Imports & Exports & $\begin{array}{c}\text { Apparent } \\
\text { consumption }^{1}\end{array}$ \\
\hline \multicolumn{5}{|l|}{ Africa: } \\
\hline .................. & - & 14,126 & - & 14,126 \\
\hline Angola... & - & 762 & - & 762 \\
\hline Congo (Kinshasa).............................. & - & 54 & - & 54 \\
\hline Egypt ........................ & - & 2,431 & - & 2,431 \\
\hline Kenya.. & - & 36 & $\left({ }^{2}\right)$ & 36 \\
\hline Malawi ................ & - & 4 & - & 4 \\
\hline 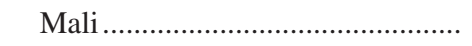 & - & 40 & - & 40 \\
\hline Mauritius... & - & 23 & - & 23 \\
\hline Morocco .......... & - & 1,206 & - & 1,206 \\
\hline 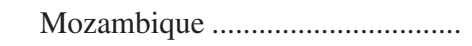 & - & 233 & - & 233 \\
\hline 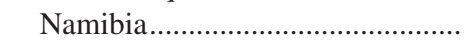 & - & - & 32 & -32 \\
\hline 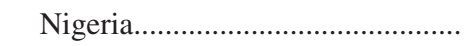 & - & 660 & - & 660 \\
\hline 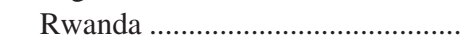 & - & 3 & - & 3 \\
\hline 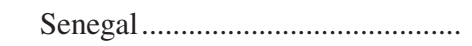 & - & 1,382 & NA & 1,382 \\
\hline 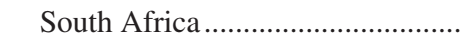 & 372 & 5,923 & 9,743 & $-3,448$ \\
\hline 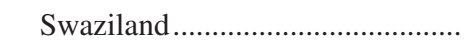 & - & - & 1,372 & $-1,372$ \\
\hline 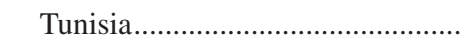 & - & 1,450 & - & 1,450 \\
\hline 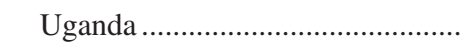 & - & $\left({ }^{2}\right)$ & - & $\left({ }^{2}\right)$ \\
\hline 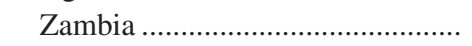 & - & 1,069 & - & 1,069 \\
\hline 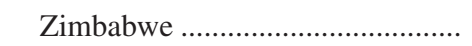 & 168,000 & 1 & 78,242 & 89,759 \\
\hline Total ............. & 168,372 & 29,403 & 89,389 & 108,386 \\
\hline \multicolumn{5}{|l|}{ Asia and the Middle East: } \\
\hline 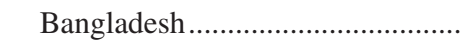 & - & 1,467 & - & 1,467 \\
\hline 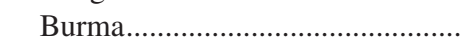 & - & 601 & - & 601 \\
\hline 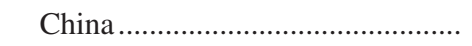 & 270,000 & 113,486 & 5,029 & 378,457 \\
\hline 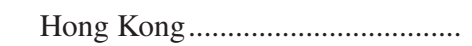 & - & 970 & - & 970 \\
\hline India & 18,000 & 150,461 & 169 & 168,292 \\
\hline 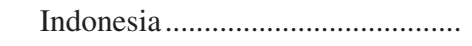 & - & 34,633 & 14 & 34,618 \\
\hline Iran & - & 46,265 & - & 46,265 \\
\hline Iraq & - & 60 & - & 60 \\
\hline 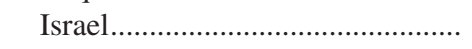 & - & 175 & - & 175 \\
\hline 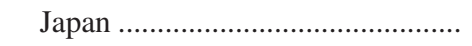 & - & 44,550 & 29 & 44,521 \\
\hline 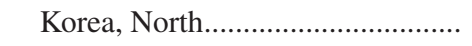 & - & 893 & - & 893 \\
\hline 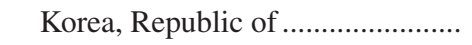 & - & 18,044 & 9 & 18,035 \\
\hline Malaysia ...................... & - & 10,645 & 38 & 10,607 \\
\hline 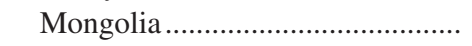 & - & 192 & - & 192 \\
\hline 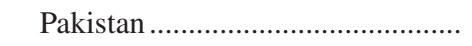 & - & 1,530 & - & 1,530 \\
\hline 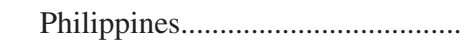 & - & 2,764 & 25 & 2,738 \\
\hline 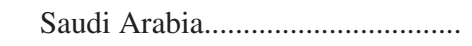 & - & 14 & 4,594 & $-4,579$ \\
\hline 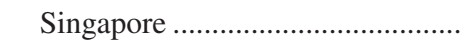 & - & $\left({ }^{2}\right)$ & - & $\left({ }^{2}\right)$ \\
\hline 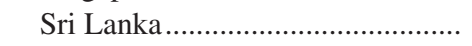 & - & 8,659 & - & 8,659 \\
\hline 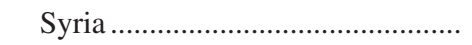 & - & 50 & - & 50 \\
\hline 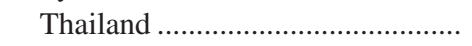 & - & 109,684 & - & 109,684 \\
\hline 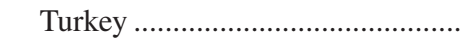 & - & 13,564 & 3 & 13,561 \\
\hline United Arab Emirates ....................... & - & 10,091 & - & 10,091 \\
\hline 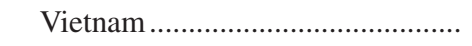 & - & 27,885 & - & 27,885 \\
\hline 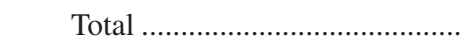 & 288,000 & 596,682 & 9,911 & 874,771 \\
\hline
\end{tabular}


Table A18. Asbestos production, trade, and consumption in 2002.-Continued

[Data in metric tons. Terms used: NA, not available; - , zero. Data are unrounded but are believed to be accurate to no more than three significant digits. Production, import, and export data from United Nations Statistics Division, 2005; Virta, 2005a]

\begin{tabular}{|c|c|c|c|c|}
\hline Region and country & Production & Imports & Exports & $\begin{array}{c}\text { Apparent } \\
\text { consumption }\end{array}$ \\
\hline \multicolumn{5}{|l|}{ Central and North America: } \\
\hline 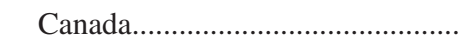 & 240,500 & 24 & 235,138 & 5,386 \\
\hline 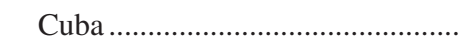 & - & 10,196 & - & 10,196 \\
\hline Dominican Republic ......................... & - & 125 & - & 125 \\
\hline 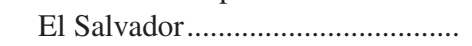 & - & 2,473 & - & 2,473 \\
\hline Guatemala & - & - & 1 & -1 \\
\hline 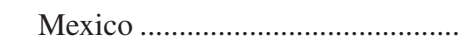 & - & 21,088 & 1 & 21,087 \\
\hline 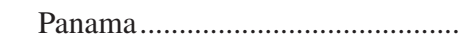 & - & 1,068 & - & 1,068 \\
\hline 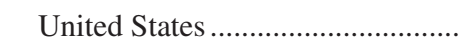 & 2,722 & 6,672 & ${ }^{3} 6,866$ & 2,528 \\
\hline Total ....... & 243,222 & 41,647 & 242,007 & 42,862 \\
\hline \multicolumn{5}{|l|}{ Europe: } \\
\hline 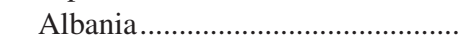 & - & 29 & - & 29 \\
\hline 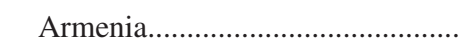 & - & 247 & - & 247 \\
\hline 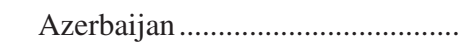 & - & 8,928 & - & 8,928 \\
\hline Bosnia and Herzegovina ................ & - & 20 & - & 20 \\
\hline 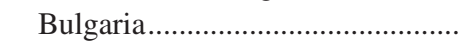 & - & 612 & 9 & 603 \\
\hline 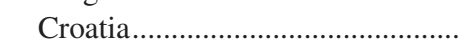 & - & 3,493 & 20 & 3,473 \\
\hline 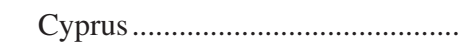 & - & - & $\left({ }^{2}\right)$ & $\left({ }^{2}\right)$ \\
\hline 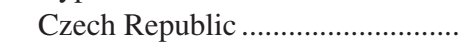 & - & 943 & - & 943 \\
\hline 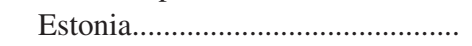 & - & 390 & 387 & 3 \\
\hline 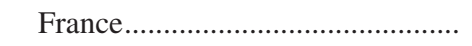 & - & 1 & - & 1 \\
\hline 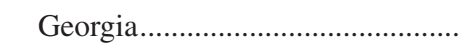 & - & 247 & 247 & $\left({ }^{2}\right)$ \\
\hline 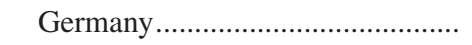 & - & 141 & - & 141 \\
\hline 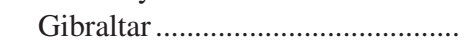 & - & 1 & - & 1 \\
\hline 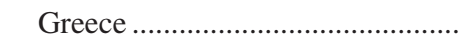 & - & - & 29 & -29 \\
\hline 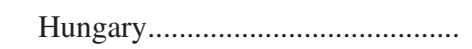 & - & 355 & - & 355 \\
\hline Italy ................ & 一 & 26 & - & 26 \\
\hline Kazakhstan............. & 291,000 & 1,912 & 117,327 & 175,584 \\
\hline Kyrgyzstan ..... & - & 21,048 & - & 21,048 \\
\hline Lithuania ............ & 一 & 10 & - & 10 \\
\hline 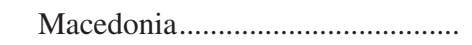 & - & 123 & 1 & 122 \\
\hline 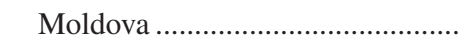 & - & 361 & NA & 361 \\
\hline 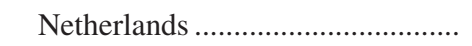 & - & 4 & - & 4 \\
\hline Poland & - & 387 & - & 387 \\
\hline 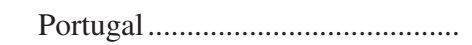 & - & 6,537 & 6 & 6,531 \\
\hline 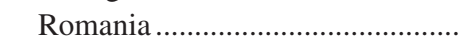 & - & 12,875 & 28 & 12,847 \\
\hline 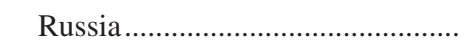 & 775,000 & 11,789 & 370,929 & 415,860 \\
\hline Serbia and Montenegro ..................... & - & 9 & 48 & -39 \\
\hline 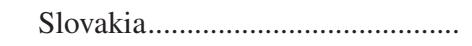 & - & 575 & - & 575 \\
\hline Spain & - & 2,261 & 1 & 2,260 \\
\hline 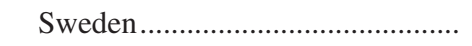 & & - & 10 & -10 \\
\hline 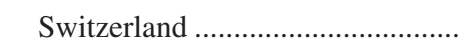 & - & - & $\left({ }^{2}\right)$ & $\left({ }^{2}\right)$ \\
\hline 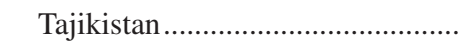 & - & 51 & - & 51 \\
\hline 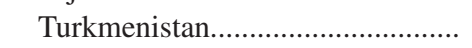 & - & 1,925 & - & 1,925 \\
\hline 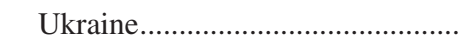 & - & 115,613 & 361 & 115,252 \\
\hline
\end{tabular}


Table A18. Asbestos production, trade, and consumption in 2002.-Continued

[Data in metric tons. Terms used: NA, not available; - , zero. Data are unrounded but are believed to be accurate to no more than three significant digits. Production, import, and export data from United Nations Statistics Division, 2005; Virta, 2005a]

\begin{tabular}{|c|c|c|c|c|}
\hline Region and country & Production & Imports & Exports & $\begin{array}{c}\text { Apparent } \\
\text { consumption }\end{array}$ \\
\hline \multicolumn{5}{|l|}{ Europe (continued): } \\
\hline 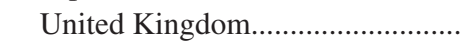 & - & 107 & 1 & 106 \\
\hline 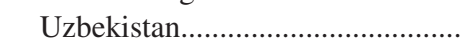 & - & 15,285 & - & 15,285 \\
\hline Total ......... & $1,066,000$ & 206,303 & 489,404 & 782,899 \\
\hline \multicolumn{5}{|l|}{ Oceania: } \\
\hline 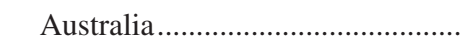 & - & 491 & NA & 491 \\
\hline 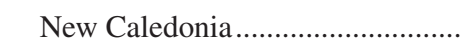 & - & - & 1 & -1 \\
\hline Total ................. & - & 491 & 1 & 490 \\
\hline \multicolumn{5}{|l|}{ South America: } \\
\hline 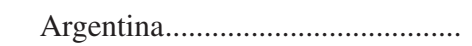 & 155 & 1,000 & - & 1,155 \\
\hline 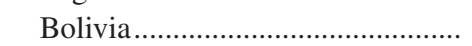 & - & 883 & - & 883 \\
\hline 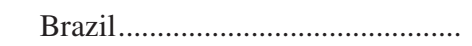 & 194,750 & 28,326 & 99,341 & 123,735 \\
\hline 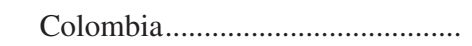 & 5,000 & 13,071 & - & 18,071 \\
\hline 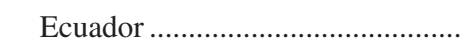 & - & 2,779 & - & 2,779 \\
\hline 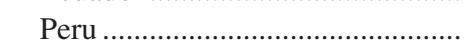 & - & 547 & - & 547 \\
\hline 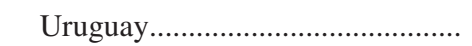 & - & 32 & - & 32 \\
\hline 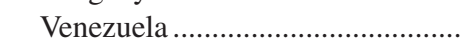 & - & 1,246 & - & 1,246 \\
\hline 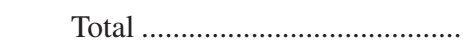 & 199,905 & 47,884 & 99,341 & 148,448 \\
\hline Unknown trade destinations.............. & - & 7,660 & - & 7,660 \\
\hline 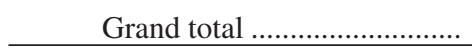 & $1,965,499$ & 930,070 & 930,052 & $1,965,517$ \\
\hline
\end{tabular}

${ }^{1}$ Apparent consumption calculated as production plus imports minus exports, not adjusted to account for changes in government and industry stocks. Negative values indicate shipments from stocks.

${ }^{2}$ Less than $0.5 \mathrm{t}$.

${ }^{3}$ Includes exports and reexports of asbestos fiber. 
Table A19. Asbestos production, trade, and consumption in 2003.

[Data in metric tons. Term used: —, zero. Data are unrounded but are believed to be accurate to no more than three significant digits. Production, import, and export data from United Nations Statistics Division, 2005; Virta, 2005a]

\begin{tabular}{|c|c|c|c|c|}
\hline Region and country & Production & Imports & Exports & $\begin{array}{c}\text { Apparent } \\
\text { consumption }^{1}\end{array}$ \\
\hline \multicolumn{5}{|l|}{ Africa: } \\
\hline 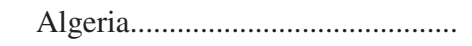 & - & 10,756 & - & 10,756 \\
\hline 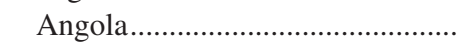 & - & 1,364 & - & 1,364 \\
\hline Benin & - & 99 & - & 99 \\
\hline 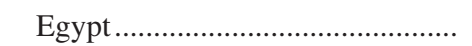 & - & 2,382 & - & 2,382 \\
\hline 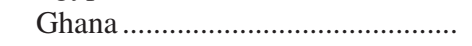 & - & 65 & - & 65 \\
\hline 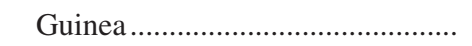 & - & 4 & - & 4 \\
\hline 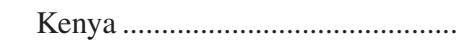 & - & 84 & $\left({ }^{2}\right)$ & 84 \\
\hline 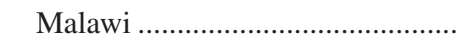 & - & 2 & - & 2 \\
\hline 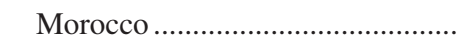 & - & 1,478 & - & 1,478 \\
\hline 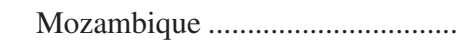 & - & 320 & - & 320 \\
\hline 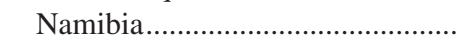 & - & - & $\left({ }^{2}\right)$ & $\left({ }^{2}\right)$ \\
\hline 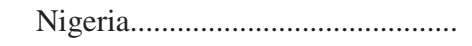 & - & 561 & - & 561 \\
\hline 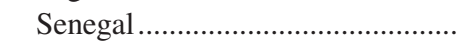 & - & 1,628 & 377 & 1,251 \\
\hline 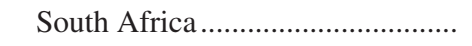 & 6,218 & 1,470 & 4,192 & 3,496 \\
\hline 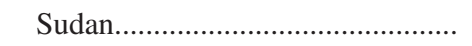 & - & 91 & - & 91 \\
\hline 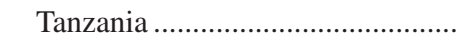 & - & 2 & - & 2 \\
\hline Togo ................ & - & 259 & - & 259 \\
\hline Tunisia............. & - & 1,020 & - & 1,020 \\
\hline Zambia ........ & - & 408 & - & 408 \\
\hline Zimbabwe . & 147,000 & 1 & 99,262 & ${ }^{3} 5,000$ \\
\hline Total ........ & 153,218 & 21,994 & 103,831 & 28,642 \\
\hline \multicolumn{5}{|l|}{ Asia and the Middle East: } \\
\hline 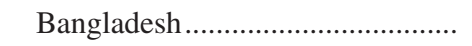 & - & 2,802 & - & 2,802 \\
\hline 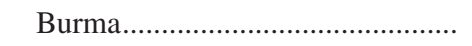 & - & 2 & - & 2 \\
\hline 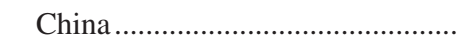 & 350,000 & 145,425 & 3,472 & 491,954 \\
\hline 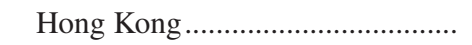 & - & 2 & - & 2 \\
\hline 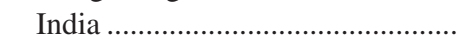 & 19,000 & 175,581 & 2,548 & 192,033 \\
\hline 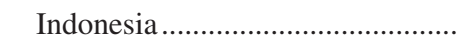 & - & 32,306 & 22 & 32,284 \\
\hline Iran & - & 75,852 & 12 & 75,840 \\
\hline Iraq & - & 12 & - & 12 \\
\hline 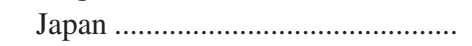 & - & 23,459 & 22 & 23,437 \\
\hline 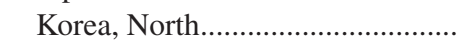 & - & 1,234 & - & 1,234 \\
\hline 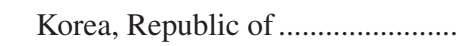 & - & 23,862 & 62 & 23,799 \\
\hline 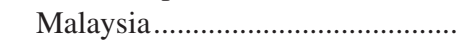 & - & 13,439 & - & 13,439 \\
\hline 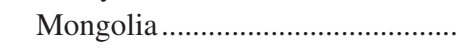 & - & 310 & - & 310 \\
\hline 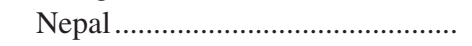 & - & 25 & - & 25 \\
\hline 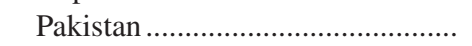 & - & 3,129 & - & 3,129 \\
\hline 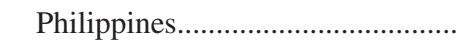 & - & 2,453 & - & 2,453 \\
\hline 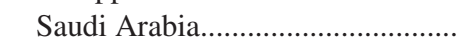 & - & 7 & - & 7 \\
\hline 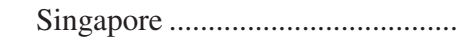 & - & 269 & $\left({ }^{2}\right)$ & 268 \\
\hline 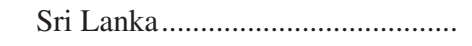 & - & 6,106 & - & 6,106 \\
\hline 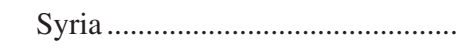 & - & 1,209 & - & 1,209 \\
\hline 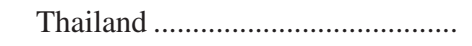 & - & 133,110 & 127 & 132,983 \\
\hline 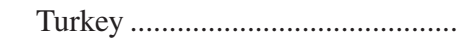 & - & 13,552 & 42 & 13,510 \\
\hline United Arab Emirates ..................... & - & 9,112 & - & 9,112 \\
\hline 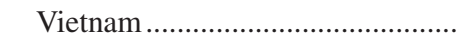 & 一 & 39,382 & - & 39,382 \\
\hline 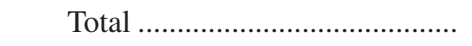 & 369,000 & 702,640 & 6,307 & $1,065,333$ \\
\hline
\end{tabular}


Table A19. Asbestos production, trade, and consumption in 2003.-Continued

[Data in metric tons. Term used: - , zero. Data are unrounded but are believed to be accurate to no more than three significant digits. Production, import, and export data from United Nations Statistics Division, 2005; Virta, 2005a]

\begin{tabular}{|c|c|c|c|c|}
\hline Region and country & Production & Imports & Exports & $\begin{array}{c}\text { Apparent } \\
\text { consumption' }\end{array}$ \\
\hline \multicolumn{5}{|l|}{ Central and North America: } \\
\hline Canada.... & 194,350 & 205 & 174,774 & 19,781 \\
\hline . & - & 9,896 & - & 9,896 \\
\hline Dominican Republic ......................... & - & 75 & - & 75 \\
\hline 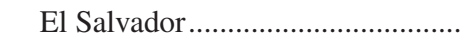 & - & 2,600 & - & 2,600 \\
\hline Guatemala .... & - & - & $\left({ }^{2}\right)$ & $\left({ }^{2}\right)$ \\
\hline 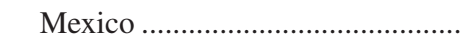 & - & 20,105 & 20 & 20,085 \\
\hline 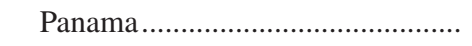 & - & 1,080 & - & 1,080 \\
\hline 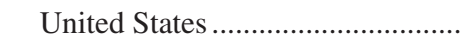 & - & 4,634 & ${ }^{4} 3,548$ & ${ }^{5} 4,634$ \\
\hline 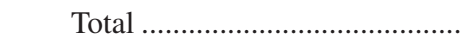 & 194,350 & 38,596 & 178,342 & 58,152 \\
\hline \multicolumn{5}{|l|}{ Europe: } \\
\hline 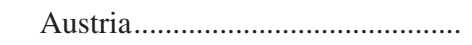 & - & $\left({ }^{2}\right)$ & - & $\left({ }^{2}\right)$ \\
\hline 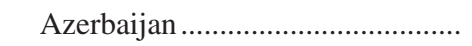 & - & 10,181 & - & 10,181 \\
\hline 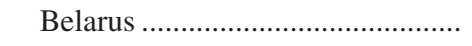 & - & - & 61 & -61 \\
\hline Belgium and Luxembourg ............. & - & 111 & - & 111 \\
\hline Bosnia and Herzegovina ................. & - & - & 1 & -1 \\
\hline 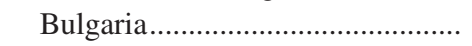 & - & 108 & $\left({ }^{2}\right)$ & 108 \\
\hline 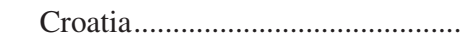 & - & 2,709 & - & 2,709 \\
\hline Czech Republic ................. & - & 1,610 & $\left({ }^{2}\right)$ & 1,610 \\
\hline 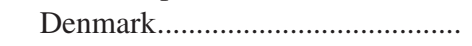 & - & - & 3 & -3 \\
\hline Estonia........ & - & - & $\left({ }^{2}\right)$ & $\left({ }^{2}\right)$ \\
\hline France........................... & - & - & 5 & -5 \\
\hline 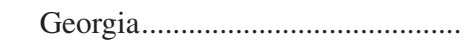 & - & $\left({ }^{2}\right)$ & - & $\left({ }^{2}\right)$ \\
\hline 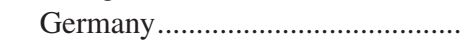 & - & 102 & - & 102 \\
\hline 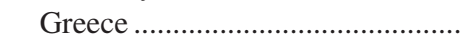 & - & - & 13 & -13 \\
\hline 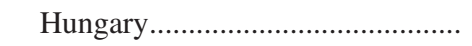 & - & 329 & - & 329 \\
\hline 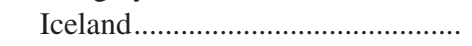 & - & 3 & - & 3 \\
\hline 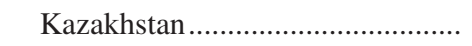 & 354,500 & 3,340 & 183,949 & 173,891 \\
\hline 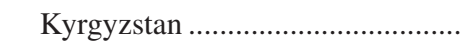 & - & 23,652 & - & 23,652 \\
\hline 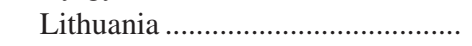 & - & - & $\left({ }^{2}\right)$ & $\left({ }^{2}\right)$ \\
\hline 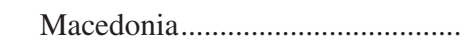 & - & 50 & - & 50 \\
\hline 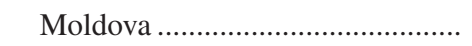 & - & 956 & 7 & 949 \\
\hline 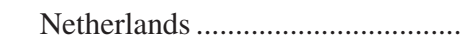 & - & 2 & - & 2 \\
\hline 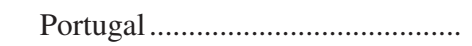 & - & 1,648 & $\left({ }^{2}\right)$ & 1,648 \\
\hline 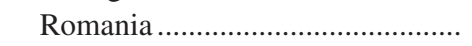 & - & 11,400 & 113 & 11,286 \\
\hline 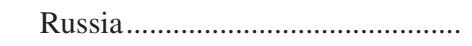 & 878,000 & 1,050 & 450,031 & 429,020 \\
\hline 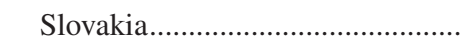 & - & 240 & - & 240 \\
\hline 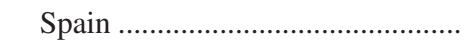 & - & 2 & - & 2 \\
\hline 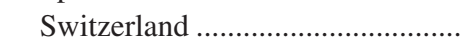 & - & - & $\left({ }^{2}\right)$ & $\left({ }^{2}\right)$ \\
\hline 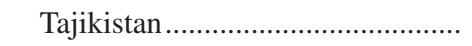 & - & 490 & - & 490 \\
\hline 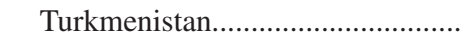 & - & 1,849 & - & 1,849 \\
\hline 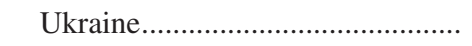 & - & 156,393 & - & 156,393 \\
\hline United Kingdom................................ & - & 23 & $\left({ }^{2}\right)$ & 22 \\
\hline 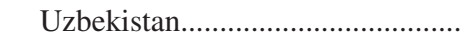 & 一 & 42,362 & 一 & 42,362 \\
\hline 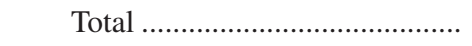 & $1,232,500$ & 258,609 & 634,182 & 856,927 \\
\hline
\end{tabular}


Table A19. Asbestos production, trade, and consumption in 2003.-Continued

[Data in metric tons. Term used: - , zero. Data are unrounded but are believed to be accurate to no more than three significant digits. Production, import, and export data from United Nations Statistics Division, 2005; Virta, 2005a]

\begin{tabular}{|c|c|c|c|c|}
\hline Region and country & Production & Imports & Exports & $\begin{array}{c}\text { Apparent } \\
\text { consumption }\end{array}$ \\
\hline \multicolumn{5}{|l|}{ Oceania: } \\
\hline 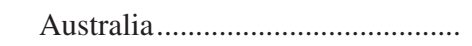 & - & 20 & 1 & 19 \\
\hline 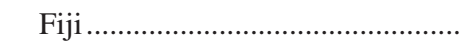 & - & 1 & - & 1 \\
\hline Total ................ & - & 21 & 1 & 20 \\
\hline \multicolumn{5}{|l|}{ South America: } \\
\hline Argentina....... & 166 & - & - & 166 \\
\hline Bolivia ............. & - & 1,159 & - & 1,159 \\
\hline Brazil...... & 194,350 & 28,395 & 144,343 & 78,403 \\
\hline Colombia.. & 5,000 & 8,118 & - & 13,118 \\
\hline Ecuador ........... & - & 1,458 & - & 1,458 \\
\hline Peru .......................... & - & 492 & $\left({ }^{2}\right)$ & 492 \\
\hline 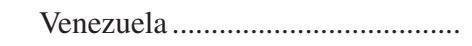 & - & 1,464 & - & 1,464 \\
\hline 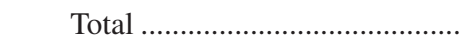 & 199,516 & 41,086 & 144,343 & 96,260 \\
\hline Unknown trade destinations............... & - & 3,609 & - & 3,609 \\
\hline 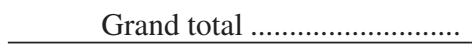 & $2,148,584$ & $1,066,556$ & $1,067,006$ & $2,108,943$ \\
\hline
\end{tabular}

${ }^{1}$ Apparent consumption calculated as production plus imports minus exports, not adjusted to account for changes in government and industry stocks. Negative values indicate shipments from stocks.

${ }^{2}$ Less than $0.5 \mathrm{t}$.

${ }^{3}$ For Zimbabwe, which has a small manufacturing capacity for asbestos products, the calculated apparent consumption probably includes about 42,739 $\mathrm{t}$ going into stocks and 5,000 t of estimated consumption.

${ }^{4}$ Includes exports and reexports of asbestos fiber.

${ }^{5}$ For the United States, the apparent consumption is assumed to equal the imports. 
